\title{
„CUIUS CORPUS REQUIESCIT IN ECCLESIA AGRIENSI..."*
}

\author{
HAVASI KRISZTINA**
}

The study presents the findings of the archaeological investigation and architectural survey of the vaulted ashlar burial chamber and its burial in Eger Cathedral. The burial chamber is located in the cathedral's longhouse, whose origins can be traced to the Árpádian Age. In addition to an overview of the relevant medieval and post-medieval historical sources and the archival architectural and archaeological reports, the context and the date of the burial chamber in the architectural history of the medieval cathedral are also discussed, as is its association with the other burials in the cathedral.

Keywords: Eger, medieval cathedral, burials in the cathedral, Árpádian Age, prominently located burial chamber, King Emerich (r. 1196-1204)

A tanulmány a középkori egri székesegyház Árpád-kori eredetü hosszházában fennmaradt kváderfalazatú, boltozott sirkamra és az abba befoglalt sírhely maradványaival kapcsolatos helyszini (elsősorban épületrégészeti) megfigyelések, felmérések eredményeit adja közre. A munka a vonatkozó középkori és újkori történeti források, valamint az archív müemléki és régészeti dokumentumok áttekintése mellett vizsgálja a kitüntetett helyzetü sírkamrának a középkori székesegyház épitéstörténetében elfoglalt helyét, korát és az épületen belüli temetkezésekkel való összefüggését.

Kulcsszavak: Eger, középkori székesegyház, székesegyházon belüli temetkezések, Árpád-kor, királysírok, kitüntetett helyzetü sírkamra, Imre király (1196-1204)

„...Az egyházi szertartások és az ünnepi szentmise befejeztével nem úgy, mint néhány más, régen elhunyt királyt, akiket más írásos elbeszélések tiszteletre méltó tekintélye a legboldogabb emlékezetúnek mond, azaz nem letakart arccal, sem néhány napig elrejtve a holttestét ahogyan némely alkalommal egyes királyok elhunytakor állítólag ezt a helytelen szokást alakították ki -, hanem nyilvánosan mindenki jelenlétében, úgy, hogy nyíltan, személyesen látták, a mondott testet Fehérvárra szállították, hogy eltemessék..."1

A kézirat beérkezett: 2017. április 5 .

* Chronici hungarici compositio saeculi XIV. In: SRH I, 463. A tanulmány a szerző 2011-ben megvédett doktori disszertációja azonos címú fejezetének (Havasi 2011, 143-163) szerkesztett és javított változata. Az itt olvasható munka tartalma a 2011 tavaszán lezárt állapotokat tükrözi, a témát érintó újabb irodalmat a lábjegyzetekben külön jeleztük. A doktori
Az Árpádok kihalt dinasztiájának magyarországi trónját elsőként elfoglaló Anjou uralkodó, Károly Róbert (†1342) haláláról és temetéséről beszámoló - vélhetóen I. (Nagy) Lajos (13421382) udvari papjától és krónikásától, a Johannes de Agria-val, avagy Kétyi Jánossal azonosított Névtelen Minoritától származó - fenti krónika-

dolgozat kiadásának előkészítése és a kapcsolódó feldolgozó munka az „Adalékok az Árpád-kori múvészet történetéhez" címú (NKFIH/OTKA PD 112126. sz.) kutatási program keretében folyik.

** Havasi Krisztina. MTA BTK Múvészettörténeti Intézet; havasi.krisztina@btk.mta.hu

1 Károly király halála. In: BELLUS-KRISTó 2001, 171-177, különösen 174; vÖ. BERTÉNYI 2000, 93, valamint A Névtelen Minorita Krónikatöredéke (részletek). In: BERTÉNYI 2000, 146-150 (különösen 146); KRISTÓ 2000, 89-117. 
részlet nemcsak az első olyan forrás idehaza, amely kissé részletesebben tudósít a királytemetési szertartás mikéntjéről, hanem egyben figyelemre méltó utalásokat tartalmaz annak az utolsó(?) Árpádok alatt „helytelenül” megváltozott módjáról. Az a szokás, hogy az uralkodót a külvilágtól elzárva, letakart arccal ravatalozzák fel és általában a királytemetés mikéntje - a szentté avatások kivételes eseteit leszámítva - a források nyomán szinte megragadhatatlan a magyarországi középkor első három századában. A szentté avatott uralkodók, István király és Imre herceg 1083-as, valamint László király 1192-es kanonizációja kapcsán keletkezett, az elevatio-t, translatio-t is elbeszélő legendairodalomtól, valamint a 11. századból származó, Aba Sámuel és Domoszló herceg földi maradványainak áthelyezésére vonatkozó forrásoktól eltekintve a 11-12. századi királyokról a 14. századi krónikakompozíció és a zágrábi krónika szúkszavú, csupán az uralkodó elhunytáról és nyughelyéról megemlékező passzusaira hagyatkozhatunk. ${ }^{2}$ Ezek fényében Károly Róbert temetése kapcsán „,a helytelen szokás elhagyása mellett" megragadható egy másik változ(tat)ás is egy másik, a megelőző században dívó "hagyományon”. Ez pedig a temetés helyére, helyszínére vonatkozik.

Károly Róbert ugyanis az Árpádokkal való dinasztikus rokonságot, egyben a Szent István-i tradíció folytatását hangsúlyozandó bő másfél évszázad, azaz III. Béla (1172-1196) király óta az első uralkodó volt, aki ismét az István király (1000-1038) által alapított székesfehérvári bazilikában, Szent István és egy sor Árpád-házi uralkodó közelében szeretett volna örök nyugalmat találni. Az új dinasztikus temetkezőhely kijelölésében nem mellékes szerepe lehetett azon törekvésnek, mely e 12. századi tradíció s a kontinuitás felélesztése révén az új uralkodóház legitimációját még inkább megalapozottnak látta. A fehérvári Szúz Mária-prépostsági templom ehhez is kapcsolódó Anjou-kori átépítésével és kibóvítésével a források és a fennmaradt építészeti töredékek alapján régóta számol a kutatás. ${ }^{3}$ Ha "helytelen szokás" maga nem is, de a temetkezések helyszíneinek változása nyomon követ-

2 KovÁcs B. 1968, 124-125; KovÁcs B. 1987, 96-97; DHA I, 77; MEZŐ 2003, 351; HAVASI 2004, 50, 126. jegyzet; a kolostortemplomról: PARAdisum Plantavit 2001, 328-334; Bodó 2010, 350-351.

3 DERCSÉNYI 1943, 49-56; SZÉKESFEHÉRVÁR 1982, 165-203 (Kralovánszky Alán, Lővei Pál, Szakál Ernő írásai); Biczó Piroska a prépostsági templom déli oldalán végzett ásatásainak eredményei, valamint újabb kutatások az Anjousíremlékekre nézve: BIczó 2004a, 32-35 (kutatástörténeti áttekintés); BICzó 2004b, 48-57; LŐVEI 2004, 72-85; BICZÓ 2011a, 139-170; Bı́Zó 2011b, 22-26; LőVEI 2011, 171-187. hető Károly Róbert 13. századi király elődeinél. Ök elsősorban a rendi templomokat részesítették előnyben: III. András (1290-1301) a budai ferenceseknél, ${ }^{4}$ IV. (Kun) László (1272-1290) Csanádon, ${ }^{5}$ V. István (1270-1272) a margitszigeti domonkosoknál, ${ }^{6}$ IV. Béla (1235-1270) az esztergomi ferenceseknél nyugodott. ${ }^{7}$ A század vége felé Buda előtérbe kerülése mellett szembetúnő a koldulórendek preferálása. Ezek udvari befolyásában IV. Béla trónra lépése évében, 1235-ben szentté avatott húgának, Erzsébetnek (12071231), majd lányának, Margitnak is fontos szerepe lehetett. II. András (1205-1235) alatt a 12. század vége óta a királyi udvarban hasonlóképp komoly szereppel bíró ciszterciekre esett a választás, amit az 1213-ban meggyilkolt Andechs-Merani Gertrúdnak a tetthely közelében való pilisszentkereszti, ${ }^{8}$ később a királynak és második nejének az egresi ciszterci apátsági templomban történt eltemetése is hangsúlyozott. Ez a tendencia, az uralkodócsalád és a ciszterci rend szoros, kolostorok alapításában és azok temetkezőhelyként való kiválasztásában megnyilvánuló összefonódása a 12. század vége felé, az 1200-as évek elején a magyar királyi udvar mellett másutt - így a szomszédos Babenbergeknél - is megfigyelhető volt. ${ }^{9}$ A ciszterciek, utóbb a koldulórendek elő-

4 SRH I, 478; a budai ferences templom Altmann Júlia által folytatott régészeti kutatásai nyomán előkerült római szarkofággal összefüggésben: То́тн S. 1994, 86.

5 SRH I. 474

6 SRH I, 471; F. VATTAI 1966/1967, 123-136.

7 SRH I, 469-470; síremlékéről, sírfeliratáról többek között: PANNONIA ReGIA 1994, 274-275. Kat. IV-47. (Horváth István, Takács Imre).

8 Gertrudis királyné pilisszentkereszti temetkezéséhez és síremlékéhez: TAKÁcS 1994, 248-251 (korábbi irodalommal); TAKÁCS 1998, 103-109. Újabban: LASZLOVSZKY 2014, 125-148; BENKŐ 2014, 173-188; TAKÁCS 2014, 189-202.

9 A magyarországi szituációnak, a királyi központnak és az ahhoz közeli, nagy befolyású ciszterci apátságnak, Esztergomnak és Pilisszentkeresztnek a VI. Babenberg Lipót (1198-1230) korabeli ausztriai fejleményekkel való összehasonlítása: MAROSI 1998, 117-121. A Babenbergek a III. Lipót (1095-1136) által a fia, Freisingi Ottó püspök (†1158) kezdeményezésére alapított heiligenkreuzi ciszterci apátságba temetkeztek. 1236-1240 között II. Henrik 1143-ban elhunyt feleségének, Braunschweigi Gertrudnak a maradványait is áthozták Klosterneuburgból Heiligenkreuzba, nem sokkal később az utolsó Babenberg herceget, Harcias Frigyest (†1246) is itt temették el.

A lilienfeldi ciszterci apátságot VI. Lipót (1195/1198-1230) 1202-ben alapította, azt kifejezetten temetkezési helyéül is szánta. A kérdéskörhöz többek között lásd: SEEGER 1997; SCHWARZ 1998a, Kat. 47, 256-257; SCHWARZ 1998b, Kat. 69, 299-301; DAHM 1998, 398-399 (a síremlék további irodalmával). A ciszterciek a templomban eltemethető személyek tekintetében szigorú feltételeket szabtak, a korai generális káptalanok intézkedései ezt csak királyok, királynék, érsekek és püspökök, utóbb apátok számára tették lehetővé. Az 1152es generális káptalan határozatát az 1180-as annyiban módo- 
térbe kerülését a 13. század folyamán a királyi udvarban és a királyi temetkezések körül számos szempontból feltárta, vizsgálta már a kutatás, miként a megelőző század fehérvári királytemetkezéseinek sorát és azok aspektusait is. ${ }^{10}$ István király capella propria-jának, a királyok koronázótemplomának dinasztikus temetkezőhellyé való formálódása a 12. század elejétől követhető nyomon. István közvetlen, 11. századi utódai épp az ecclesia propria, a saját kezdeményezésre történt alapítás és építkezés, a maguk által építtetett egyházba való temetkezés terén követték az első királyt. ${ }^{11}$ A 12. századi, Kálmán királytól (†1116) III. Béláig (†1196) terjedő sorban a szentté avatott király és herceg sírjának közelébe való temetkezés, a sepultura ad sanctos motivációja ${ }^{12}$ - a dinasztikus kultusz személyes vonatkozásai mindkét uralkodó idősebb fiának és örökösének névadásában is (II. István, Imre) tükröződtek -éppúgy meghatározó lehetett, mint a „bazilikának” a királyság életében betöltött kitüntetett szerepe.

A váltásra, Fehérvár elhagyására e téren azonban mégsem a III. Béla alatt még szilárd királyi hatalmat biztosító, a Szent István-i berendezkedés felbomlását „újításaival” elindító s a cisztercieket preferáló II. András idején, hanem még az atyai politika örököseként fellépó Imre király (1196-1204) alatt került sor. Az ő teste ugyanis a krónikák egybehangzó állítása szerint az egri székesegyházban nyugodott. ${ }^{13} \mathrm{~A}$ trónt - a 12-13.

sította, hogy a király és az előkelő egyháziak temetkezésének lehetőségét kiterjesztette a káptalantermekre is. A kérdéshez magyarországi vonatkozásban lásd: FüGEDI 1991, 55-56. A ciszterci apátságok és a királyi családok temetkezőhelyeinek kapcsolatához a 12. század második felében és a 13. század első felében: FÜGEDI 1991, 55; KoszTA 1993, 121 UNTERMANN 2001, 59-63; HUCKER 2001, 287-292.

10 ENGEL 1987, 616-622; FÜGEDI 1991, 55-56; TÓTH E. 2006, 141144. A 13. századi magyar uralkodótemetkezések (és azok rendi kapcsolatainak) újabb szempontokkal is bővített részletes elemzése LASZLOVSZKY 2014, 125-143, különösen: 131-138.

11 Többek között FÜGEDI 1991, 55-56; vázlatos áttekintés a 11. századi temetkezőhelyekről újabban: TóтH E. 2006, 141-144. A 11. századi magyar királyok közismert temetkezőhelyeinek felsorolásától (és monasztikus/bencés vonatkozásaik vizsgálatától) - mivel ez több helyen is fellelhető (lásd pl. az előző jegyzetekben i. m.) - itt eltekintek. A szokás megfigyelhető az Ottó-kori császárságban is Magdeburg, Merseburg, Bamberg székesegyházainak az uralkodók ottani rezidenciájával is összefüggő alapítása kapcsán. A szász Madarász Henrik (912-936) székhelyén a quedlinburgi prépostság, a bajor hercegi udvarban, Regensburgban pedig a Niedermünster töltötte be ugyanezt a szerepet. Utóbb a száli-frank II. Konrád császár (1024-1039) speyeri alapítása nyomán jött létre az első kifejezetten dinasztikus temetkezőhely. Ez utóbbiról: SCHMIDT 1984, 666-726; MEIER 1998, 37-48; WEINFURTER 2005, 157-173.

12 A jelenséghez általában: BorGOLTE 1985, 27-38; FÜGEDI 1991, 55.

13 SRH I, 211, 463. század és lényegében két korszak határán - elfoglaló Imre nyolcéves uralkodása rövid, ám történetileg, múvelődés- és múvészettörténetileg is jelentős időszakot ölel át. Ezt a király és a pápa, III. Ince általánosan jónak mondható viszonya és az András herceggel folytatott testvérháború jellemezte, s e korszak az utóbbi évek történeti kutatásainak köszönhetóen kezdett részletesebben kibontakozni az apa és a fivér évtizedeket átfogó regnálásának árnyékából. ${ }^{14}$ Hogy 1204-ben vagy 1204-re az egri székesegyház mint királyi temetkezőhely kiválasztásában milyen szempontok játszhattak közre - azaz Imre király esetében is a temetkezés tudatos és előre megválasztott helyéről volt-e szó, ${ }^{15}$ vagy más körülmények is szerephez juthattak -, arra vonatkozóan a történeti források hallgatnak. Azonban e királytemetkezésnek az emléke nemcsak az írott források révén, hanem - úgy túnik - múvészettörténeti, régészeti módszerekkel a maga valójában is megragadható. ${ }^{16}$ Maradványai, fragmentumai révén valamennyire talán szóra is bírható feltéve, ha az alábbi megfigyelések kiállják az idő és a kritika próbáját. Ezen építészeti emlék - amely köré a székesegyház egykorú töredékei közül számos csoportosítható, s amelyből közvetve-közvetlenül a székesegyház 1200 körüli átépítésének múve is magyarázható ${ }^{17}$ - vizsgálata révén néhány ponton közelebb juthatunk e királytemetkezés és e kor (szúkebb) múvészeti/történeti kontextusának megismeréséhez. ${ }^{18}$

14 Ehhez lásd többek között: SwEENEY 1993; SzABADOS 1999a; 2000; 2002.

15 Székesegyházak mint királyi temetkezőhelyek a 11. században az uralkodók alapítói és építtetői tevékenyégével szoros összefüggésben túnnek fel: Pécs, Szent Péter-székesegyház (I. Orseolo Péter †1046); Vác, Szúz Mária-székesegyház (I. Géza †1077) és Várad, Szúz Mária-székesegyház (I. László †1096). Kérdéses, hogy III. István király (†1172) esztergomi temetkezése a Szent Adalbert-székesegyházra vonatkozik-e. SRH I. 210, 462; összefoglalóan Pécshez: KMTL 1994, 538-539 (Engel Pál-Koszta László); Váchoz: KMTL 1994, 705-706 (Kubinyi András-Engel Pál-Koszta László); KoszTA 2001, 363-375; Váradhoz: KMTL 1994, 712-713 (Almási Tibor-Engel PálKoszta László).

16 Lásd Havasi 2004, 40-50; 2011, 143-163.

17 Erről: HAVASI 2003, 140-142; 2004, 40-58; SZAKÁCS 2005, 34; 2006, 183-184; HAVASI 2009, 270-271.

18 A jelen tanulmány fő megállapításaiban a 2004 márciusában leadott szakdolgozaton (HAVASI 2004, 40-59.) alapul, annak kibővített, korrigált és a 2003-2006 közötti időszak részletesebb helyszíni vizsgálataival kiegészített változata (HAVASI 2011, 143-163). A munka azonban így is vázlatos. A sírkamrát érintő 2004-2006 közötti helyszíni vizsgálatok, felmérések, megfigyelések eredményeit a korábbi ásatások adataival összevetve több, az Árpád-kori székesegyház maradványaival/építéstörténetével is összefüggő, tisztázandó épületrégészeti probléma és (vagy épp alaposabb régészeti hitelesítést is igénylő) kérdés merült fel. Ezekról többek között HAVASI 2011, 6-74, 143-224; HAVASI-MAROSI-SZAKÁCS 2012, 162-172. 


\section{Az írott források}

Középkori forrásaink közül a Zágrábi krónika és a nem sokkal utána keletkezett 14. századi krónikakompozíció tartotta fenn az Imre király 1204 őszén bekövetkezett halálára és egri eltemetésére vonatkozó adatot. ${ }^{19}$ Imrét III. Ince pápa János

Ezek közül a székesegyház nyugati részének - 14. századi toronypár és előcsarnok, valamint tőlük nyugatra eső terület - hitelesítő feltárására került sor Nagy László vezetésével 2014 november-decemberében. Erról lásd NAGY L. 2015, 92-98, valamint az ásatást megelőző szakvéleményt: Havasi K.: Szakvélemény a középkori egri székesegyház nyugati részének maradványairól. 2014. szept. 23. Forster Központ Tervtára, ltsz. 44122. (Dobó István Vármúzeum, Régészeti Adattár). A sírkamráról 2003-2006 között készült manuális felmérések (7-14. kép) is további, pl. szintadatokat és alaprajzi összefüggéseket is hitelesítő, komplex nagymúszeres felméréseket igényelnének, ekképp az itt közreadott helyszín munka dokumentumai is befejezetlenek. Az újabb fejlemények tükrében folytatásukra (vagy épp kellő alaposságú tisztázásukra) érdemi mód mostanság aligha lesz. Az egykori helyszíni munkához nyújtott segítségükért az Egri Dobó István Vármúzeum nyugalmazott munkatársainak, Fodor Lászlónak és Hollósy Zoltánnak tartozom köszönettel. 2004 óta megjelent írások "Imre király sírjával” kapcsolatban: NAGY G. B. 2006, 106-108. „A székesegyház nyugati végében van az egyetlen épített sírbolt, melyet talán Imre király nyughelyéül szántak, de ezt semmilyen további adat nem pontosítja..." Azonban „a korabeli királyi temetkezési formák alapján" elfogadja, hogy sírkamrában Imre király nyugodott, s a sír pusztulását az 1500-as évekre helyezi. KÁRPÁTI 2010, 74-80; szintén foglalkozik a sírkamrával, a királysír helyére nézve azonban más kalandos elképzeléseket hoz (ezekről lásd itt a 24. jegyzetet). Imre király temetkezéséről legutóbb: BICZÓ 2016, 30-33; valamint számos új aspektussal: LASZLOVSZKY 2014, 132-133. A kitüntetett helyzetú sírkamráról, királysírról elhangzott újabb előadások (a 12-13. század fordulójára helyezhető székesegyházi faragványcsoport(ok) és a temetkezés összefüggése szempontjából): A középkori egri székesegyház az 1200-as évek elején. Eger, Dobó István Vármúzeum, Örökségünk védelme és jövője. 2014. február 7. Továbbá (a székesegyház Árpád-kori építéstörténetével, különösen a nyugati rész 12. és 14. századi maradványaival, valamint a székesegyházon belüli főpapi temetkezésekkel, e temetkezések topográfiájával összefüggésben): Kövekbe zárt évszázadok. Bekezdés(ek) a középkori egri székesegyház építéstörténetéből. Magyar Nemzeti Múzeum, Magyar Régészeti és Múvészettörténeti Társulat közgyúlése, 2014. március 24.

19 SRH I, 211. (Chronicon Zagrabiense): „....hic sepultus est i[n] Ag[rie]..."; SRH I, 463. (Chronici Hungarici compositio saeculi XIV.): „....Migravit autem ad Dominum anno Domini M-o CC pridie Kalendas Decembris, feria III. Cuius corpus requiescit in ecclesia Agriensi." A király halálának dátuma tekintetében két hónapnyi (szeptember 30., illetve november 30.) különbséggel. Továbbá: SRH II, 41, 82. Történeti összefoglalás: PAULER 1899, II, 491-492; SRH II, 749-750 (Szovák Kornél); a székesegyház statútumaival összefüggésben fennmaradt Zágrábi krónikát a jelen álláspontok szerint 1354-ben másolták két évtizeddel korábbra helyezett mintapéldány nyomán. E mú a történészek egybehangzó véleménye szerint a 14. századi krónikák feltételezett közös forrásából a legtöbbet meríthetett és tarthatott fent. $S$ ez az egyetlen középkori krónikáink között, amely Imre halálának évét és III. László kalocsai érsek ügyében hozzá címzett, 1204. november 22-én kelt levele még ad karissimi in Christo filii nostri Hemerici, Ungaerie regis illustrisként tüntette fel. ${ }^{20} \mathrm{~A}$ király tehát ezt követően minden bizonnyal a Zágrábi krónikában foglaltaknak megfelelően - 1204. november 30-án távozhatott az élők sorából. ${ }^{21}$

Ezután már csak meglehetősen kései, 18. századi és helybeli forrásokban merül fel ismét a királytemetkezés kérdése. Az első ilyen újkori említés az 1700-as évek elejéról való, ez azonban legfeljebb kegyes hagyomány teremtésének szándékával átitatott eseményről, mintsem az uralkodó memoria-jának töretlen ápolásáról tájékoztat. Ez az említés a középkori székesegyház romjainak fennálló részletét épp a királyi temetkezésekre(!) is hivatkozva - legalábbis egy alkalom erejéig - még használni óhajtó, a hódoltság után a püspöki székhelyre elsőként visszaköltöző Telekessy István püspök (1699-1710) nevéhez fúződik. ${ }^{22}$ A közelebbről meg nem nevezett kirá-

halálának napját (elhalálozásának événél a szöveg utólagosan sérült: SZENTPÉTERY 1934, 420-421) pontosan rögzítette, és egyben az egyetlen olyan, amely az apja után majd fél évvel távozó gyermek király Egerbe való eltemetéséről is tud. „.... obit autem anno Domini MCCXI. quinto Nonas Maii, quius corpus Agrie requiescit..." A krónika bővebb filológiai-történeti elemzése: SZENTPÉTERY 1934, 410-425, Imrére és fiára vonatkozóan: 413-414, 416, 418, 420-421; A 14. századi krónikakompozíció és az azt vagy közös forrásukat követő írások egyöntetúen a gyermek székesfehérvári temetését adják hírül. Vö. ENGEL 1987, 622, 48. jegyzet. Kovács Éva a székesfehérvári bazilika területén 1839-ben előkerült egyik királysír leleteit (filigráncsík darabjai, rekeszzománcos korong, valamint egy Jankovich Miklós gyújteményében fennmaradt miniatúr korona) a regio more eltemetett gyermek III. László személyével hozta összefüggésbe: PANNONIA REgIA 1994, Kat. II-36, 211-212; ehhez kritikai észrevételekkel vö. SzAKÁCS 2002, 53-56, Fig. 32-34; SzABAdOS 2009, 167. A kisméretú korona nem tartozott az 1839-ben feltárt sír(ok) leletei közé, erről Biczó 2002, 26, 28 (24. jegyzet); Biczó 2016, 27; az 1839es feltárásra és a leletanyagára vonatkozó forrásközlés: ProHÁszKa 2011, 56-63. Köszönöm Biczó Piroskának, hogy az együttes régészeti összetartozásának problémájára felhívta a figyelmemet.

20 PAULER 1899, II, 491-492; MÁTYÁs rec. 1900, 738-740; SWEENEY 1993, 150-151; HAGENDER 1997, 273-276; SZABADOS 1999a, 18.

21 SzABADOS 1999a, 18 (különösen: 40. jegyzet). Az Imréról kegyes emlékezetú, néhai királyként megemlékező pápai irat pontos kelte (1204 vége, 1205 eleje) bizonytalan. Vö. HAGENDER 1997, 398-399. A Zágrábi krónikához és szakirodalmához lásd a 18. jegyzetben írtakat.

22 A szóban forgó forrást, Telekessy püspök levelét Schmitth Miklós közölte: „,...consenui jam ad terminos exactae aetatis pereni. Si boni superi vitam \& vires concesserint, die sexta Maii jubilaeus sacerdos ad aras consistam. Ad eam solennitatem Reverendum Patrem veteri affectu Eminentissimum Dominum meum omni cum veneratione invito. Statueram solenni pompa alteras, ut dicimus primitatis Deo offerre agriae in arcis sacello templi S. Joannis infra turrim sito sexta Maji id est die S. Joanni ante portam Latinam sacra, cuius honori Capitulum Agriense a S. 
lyok nyughelyére vonatkozó sor kapcsán feltúnő többes szám - binaque corpora Regum Hungarie eodem in sacello recondita sunt - valószínúleg a püspök és az egri jezsuiták történeti tájékozottságára vezethetô vissza. Részben talán a Zágrábi krónikából hagyományozott adatok valamiféle ismeretére utalhat, mely szerint az atyja után néhány hónappal az élők sorából távozó gyermek III. Lászlót - bár vele kapcsolatban a modern történeti kutatás inkább Székesfehérvár felé hajlik szintén Egerben temették volna el. ${ }^{23}$ Ám ezzel kapcsolatban gyanút kelthet, hogy a királyok személyét nem nevezték meg pontosan. Így az sem elképzelhetetlen, hogy a levélben a székesegyház akkor még fennálló nyugati része kapcsán leírt „liliomcsoda” s a tornyokkal összefüggésben említett "kápolnában” - in arcis sacello templi S. Joannis infra turrim situ - nyugvó királyok fordulatában a délnyugati torony először 1351-ben említett kápolnájának az akkoriak számára még valamilyen formában ismeretes - és a gyermek király nevével összecsengő - Szent László titulusa is közrejátszhatott. ${ }^{24}$ Arra nézve, hogy a tornyok (különösen a déli) területén s vélhetőleg az előcsarnokban és a déli oldalkápolnák, valamint a déli mellékhajó nyugatabbi részein fekvő (késő középkori) temetkezések a 18. században ismeretesek és láthatók (tehát valamilyen formában még megjelöltek) voltak, egy 1757-es kihallgatási jegyzőkönyv sorai nyújtanak némi tájékoztatást. ${ }^{25}$

Stephano Hungarorum Rege nuncupatum est, qua die ante annos quinquaginta Romae in collegio S. Apollinaris primam hostiam Deo litavi, rerum cum mihi negetur felicitas in sacello memoratae ecclesiae S. Joannis sacrificandi (cuius in fastigio ante annos aliquot terna lilia in festo B. M. V. divam Elisabetham visitantis, praeter naturae ordinem excrevere, binaque corpora Regum Hungarie eodem in sacello recondita sunt citra omnem episcopalem pompam sacrificium peragam \& modo ithoc praetere possim Deo immortales gratias reddam." SCHMITTH III. 1768, 358-359. A forrás említését, értelmezését lásd még: IPOLYI 1865, 168; DÉTSHY 1964a, 10 és 241-242. jegyzet. Telekessy személyéhez, pályafutásához bővebben: SUGÁR 1984, 371-393; BITSKEY 1997, 43-47.

23 III. László temetési helyére nézve vö. 18. jegyzet.

24 Ehhez lásd a székesegyház nyugati részéról írottakat: HAVASI 2011, 47-74; HAVASI -MAROSI-SZAKÁCS 2012, 170-171. Vannak olyan - a régészeti és a történeti forráskritikát mellőző elképzelések, melyek ezen 18. század eleji "hagyomány” nyomán a déli torony alatt [sic!] és még lejjebb lévő „föld alatti világban, üregekben, altemplomszerú építményekben, melyekre nézve csak képzeletünkre hagyatkozhatunk" (sic!), keresnék a király sírját. Lásd KÁRPÁTI 2010, 79. A Telekessyféle liliomcsoda eseményéhez hozzátéve, hogy a nyugati toronypár közötti előcsarnokban ténylegesen is helyet kapott két temetkezés, az egyik bizonyosan főpapi: Dörögdi Miklós egri püspöké volt - kérdés, hogy ebből a 18. században mi látszódhatott.

25 Verhör und Durchsuchung über das Graben in der Bischöfflichen alten Kürchen in der Festung Erlau, 1757, den 11 April.
Telekessy történeti érdeklődése más vonatkozásban is megnyilvánult. Többek között az egri egyházmegye első püspökének feltételezett személye, a Gellért-legendában Gellért kíséretében feltûnő, ám Egerrel csak a 17. század derekán kapcsolatba hozott Buldus püspök körüli, a 18. században elevenen ápolt kultusz kezdeményezése, melynek hatása napjainkban is érezhető, szintén az ő nevéhez füzhető. ${ }^{26}$ Ugyanakkor, mint Brezovay Jánosnak, Heves vármegye későbbi szolgabírájának 1794 márciusában Jankovich Miklóshoz (1772-1846) írott egyik leveléből kitúnik (lásd a Függeléket), a királyi temetkezés történelmi tényének ismerete a romszékesegyház iránti érdeklődésben és a 18. század végi bontási munkálatok figyelemmel kísérésében is szerepet játszott. ${ }^{27}$ Feltúnő, hogy Brezovay a szé-

Heves Megyei Levéltár, Egri Érseki Levéltár, XII-3/a. 318. 195/a. fol. 12-22. A dokumentumra Détshy Mihály hívta fel a figyelmet, aki annak egyes részleteit vizsgálta és idézte is: DÉTSHY 1964, 11, 18, 246-252. jegyzet. A forrás teljes szövegét jegyzetekkel, értelmezéssel lásd HAVASI 2011, 314-323.

26 A komoly historiográfiai érdeklődést mutató Telekessy (aki korábban győri kanonokként az ottani káptalan levéltárát is rendezte) korától lehet találkozni a Gellért-legendából származtatott (vö. SRH II, 503) Buldusnak szentként és - Melchior Inchofer 17. századi egyháztörténete (INCHOFER 1644, $393-$ 394) nyomán - egyben egri püspökként való említéseivel. Inchofer a Gellértet kísérő püspököket, Bezertust, Buldust (Buldit) és Benetát kizárásos alapon - mivel a többi Istvánkori egyházmegye elöljárói más forrásokból ismertek voltak - nyitrai, egri és veszprémi fópapokkal azonosította. Telekessy kezdeményezésére a jezsuita szemináriumban iskoladrámát adtak elő Eger vértanú püspökéről, és a helytörténetírás adatai szerint a város Szent Mihály-székesegyházában kápolnát is szenteltek neki, valamint egy 1810-es forrás „imago Beati Buldi Episcopi Agriensis” oltárképet említ a közeli kápolnai plébániatemplomban. Buldus tényleges szentté avattatására utóbb Eszterházy Károly püspök (1761/62-1799) tett eredménytelenül végződő kísérletet Rómában. Vö. NAGY Á. 1969, 28-29. (Véleménye szerint Eszterházy Károly püspök kezdeményezésére keletkezett a kápolnai templom Szent Buldus-oltára, valamint az aszalói plébánia festménye, melyen Buldust glóriával ábrázolták.) SUGÁR 1984, 23-24; BITSKEY 1997, 44-45. Telekessy István végrendelete és a hagyatékát összeíró irat (Heves Megyei Levéltár, XII/d./48. [p. 92-96] p. 95. IV/2. tétele) szintén megemlékezik Buldus ábrázolásáról. A középkori forrásokkal alá nem támasztható első püspök személye, akinek alakja a 17-18. századi egyháztörténet-írásban, különösen a török kor utáni, 18. századi helyi, hagyomány teremtésére irányuló kísérletekben gyökerezik, a várban a mai napig "jelenlévő", így például a székesegyház déli oldalán feltárt korai körtemplom tengelyében előkerült kőlapokkal bélelt, fejtámlás (kitüntetettebb alakítású) sírt (Szent) Buldus püspök temetkezési helyeként tartják számon. Ez az azonosítás az újabb régészeti szakirodalomban is feltünik: KozÁK 1990, 335-337; FODOR 2001, 209. „Valószínúsítjük, hogy az első egri püspököt, talán „Buldust” temethették ide(?).” A Szent István-kori püspökök kérdéséhez: THOROCZKAY 2009, 33-50.

27 A középkori székesegyház Eszterházy Károly püspök alatt zajlott, 1780-as 1790-es évekbeli bontásáról szóló források áttekintését további irodalommal lásd: HAVASI 2011, 1-6. 
kesegyház közelebbről nem azonosítható „,romos kriptájában" két, kváderkövekkel kirakott sír feltárása kapcsán szintén két királyi személy sírjáról, ez esetben azonban konkrétabban Imre királyéról, valamint a hitvese számára „előkészített” sírhelyről tudósít. ${ }^{28}$

\section{Régészeti dokumentumok}

A Múemlékek Országos Bizottsága közremúködésével zajló és 1928-tól a középkori székesegyház területét is kutató várásatásoknak egyik nem titkolt szándéka és reményteli célkitüzése szintén Imre király sírjának megtalálása volt. ${ }^{29} \mathrm{Az}$ akkori feltárások egyik vezetójének, Lénárt Jánosnak a hagyatékában fennmaradt és két évtizede fia, Lénárt Andor által közzétett ásatási naplótöredék 1937 januárjánál egy sírkamra feltárásáról tudósít. ${ }^{30} \mathrm{Az}$ építmény jelentőségére $\mathrm{s}$ az alábbi vizsgálatok tárgyára való tekintettel érdemes ezt itt is idézni:

„....Lassan és óvatosan befejeződik az I/20-as sírbolt féle helyiség feltárása is. A sírbolt vegyes törmelékkel volt behányva a kripta üresen talál-

28 Erről és Imre király feleségéról, Konstanciáról bővebben lásd a Függelékben közölt levelet és a hozzá tartozó jegyzeteket. A forrásban említett „,romos kriptában kiásott két kváderkövekkel kirakott sír" feltárásának helye a székesegyházon belül (ha egyáltalán itt s nem azon kívül - pl. a déli kápolnasor területén vagy az északi oldalon elókerült kőlapokkal bélelt sírok környezetében - kell keresnünk) nehezen azonosítható. Ha a "régi", Árpád-kori eredetú hosszház s nem az "új" gótikus szentély területéről lehet szó, s a 18. század végén feltárt sírhelyek túlélték a 18-19. századi kutatásokat és bontásokat, akkor a régészeti dokumentumok szerint két helyszín jöhetne szóba. Bizonyosan két, egymás melletti falazott sírhely volt egykor a nyugati toronypár által közrefogott előcsarnokban. Ezek közül azonban a tengelyben lévó Dörögdi Miklós püspök (1330-1361) sírja - mellékleteinek tanúsága szerint - az 1970-es évekig érintetlen maradt, így ez a lehetôség kevéssé valószínú. A másik falazott "sírpár" a fóhajó középső részén, az újjáépített hosszház nyugatról második pillérpárjának vonalában került elő. Ezek Kozák Károly 1969-es ásatási dokumentációjának a Forster Központ Tervtárában (ltsz. 25587, R1.) őrzött összesító alaprajzán a 24-25. számmal jelölt sírok (lásd itt 2. kép).

29 Szmrecsányi Miklósnak a Múemlékek Országos Bizottságához írott, 1933. július 1-jén kelt levele: Forster Központ, Tudományos Irattár: MOB 1933/263. Továbbá: névtelen szerző cikke: Imre király sírja felé közelednek az egri vár kutatói. Pesti Napló, 88. évf. 25. sz. (1937. január 31.), 40; LÉNÁRT 1987, 458: „Az immár 1929 óta feltárni és feltalálni óhajtott Imre király sírja, vagy annak legalább kétségtelenül megállapítható maradványának megtalálása maradt a fó cél most is s erre legalkalmasabbnak látszott a templomromok helyén végzett rendszeres földmunkáknak a folytatása attól az állapottól kezdve, ahol elhagytuk 1934 tavaszán, amikor is fel volt tárva a román apszis+északi román mellékhajó + déli kápolnasor..."

30 LÉNÁRT 1987, 462-463. tatott. ${ }^{31}$ A kripta fenekén aládolgozva talált márványtöredékek arra engednek következtetni, hogy vagy a kripta feneke volt márványmozaikkal kirakva, vagy pedig egy régibb templom padlómárványára épült a kripta s köréje a sírbolt. Az előbbi a valószínúbb feltevés, mert az egész sírbolt darázskő őstalajba mélyített s belülról falaztatott úgy, hogy a faragott kövek s a gödör hézagait kőtörmelékkel töltötték ki. Ebben márványszilánkokat is találtunk. A sírbolt és a kripta ugyanabból a kőanyagból épült, a kriptát belülról finoman habarcs fedi, e miatt olyan a színezete mintha egyetlen kőtömbből faragott kőláda volna. A sírbolt kezdete csak a délnyugati sarokban volt észrevehetó, mert a megtalálásakor az arzenál fal volt felette. (Nem alapozva a sírbolt felett, hanem áthidalva!) A sírboltban behányt törmelékben akadt összefüggés nélküli emberi csont is, egy nagyobb darab töredék valamilyen hengeres oszlopból, román ikeroszlop lábazat, késó gót konzoltöredék stb. Maga a kriptasír törmelékkel telve, sem emberi vázat, sem pénzleletet nem adott. Ellenben a kriptasír mellett északra a sírlelet földje vagy $6 \mathrm{drb}$ elmállott koponyát, egyéb emberi csontot tartalmazott. Ugyaninnen való egy márványpadlómozaik darab, (fehérmárvány romboidalak), méretei: $97 \times 65 \mathrm{~mm}$. Az eredeti habarcs nyomaival s egy fekete márványnak látszó szerpentin darab. ${ }^{32}$ Sem a sírbolt köveinek anyaga, mérete, technikája, sem a kripta nem tartalmaz semmi olyan gyanúokot, amelynek alapján az egésznek keletkezési ideje a XV. századnál korábbra tehető volna. Sajnos Imre király sírját benne is hiába reméltük. A régebbi töredékek származását a következőképp képzeljük: A XV. sz. derekán építhette valaki ezt az előkelő helyen lévő és díszes sírkamrát. A sírkamra mélyítésénél a XV. századi padlónívó alá mentek mélyen bele a darázskő őstalajba, közben rá kellett akadniok a XIII-századi márványmozaik padlóra, ezt át is törték, innen a márványtöredékek, s biztosan régebbi kripták csontmaradványaira is akadtak, ezeket pedig elhelyezték az új kripta mellett." 33

Két hónappal később Pálosi Ervinnek a Múemlékek Országos Bizottsága számára az ásatásokról írott jelentésében a következőket olvashatjuk a leletről: „A székesegyház főhajójának ten-

31 A "sírbolt" kifejezést a sírkamra, a "kripta" megjelölést pedig a kőlapokkal bélelt sírhely (továbbiakban: sírláda) kapcsán alkalmazta Lénárt.

32 E darabról van korabeli rajzvázlat is: LÉNÁRT 1987, 38-39. kép, vö. Havasi 2011, 305, Kat. 162.

33 LÉNÁRT 1987, 462-463. 1937. január 27-i bejegyzés (a sírkamra méretei és vázlatrajza: uo. 37. k.), valamint még január 18-nál (uo. 460): „....Templomfeltárás folytatása. I/20. helyen sírbolt féle mutatkozik, egy észak-déli arzenális fal alatt..." 


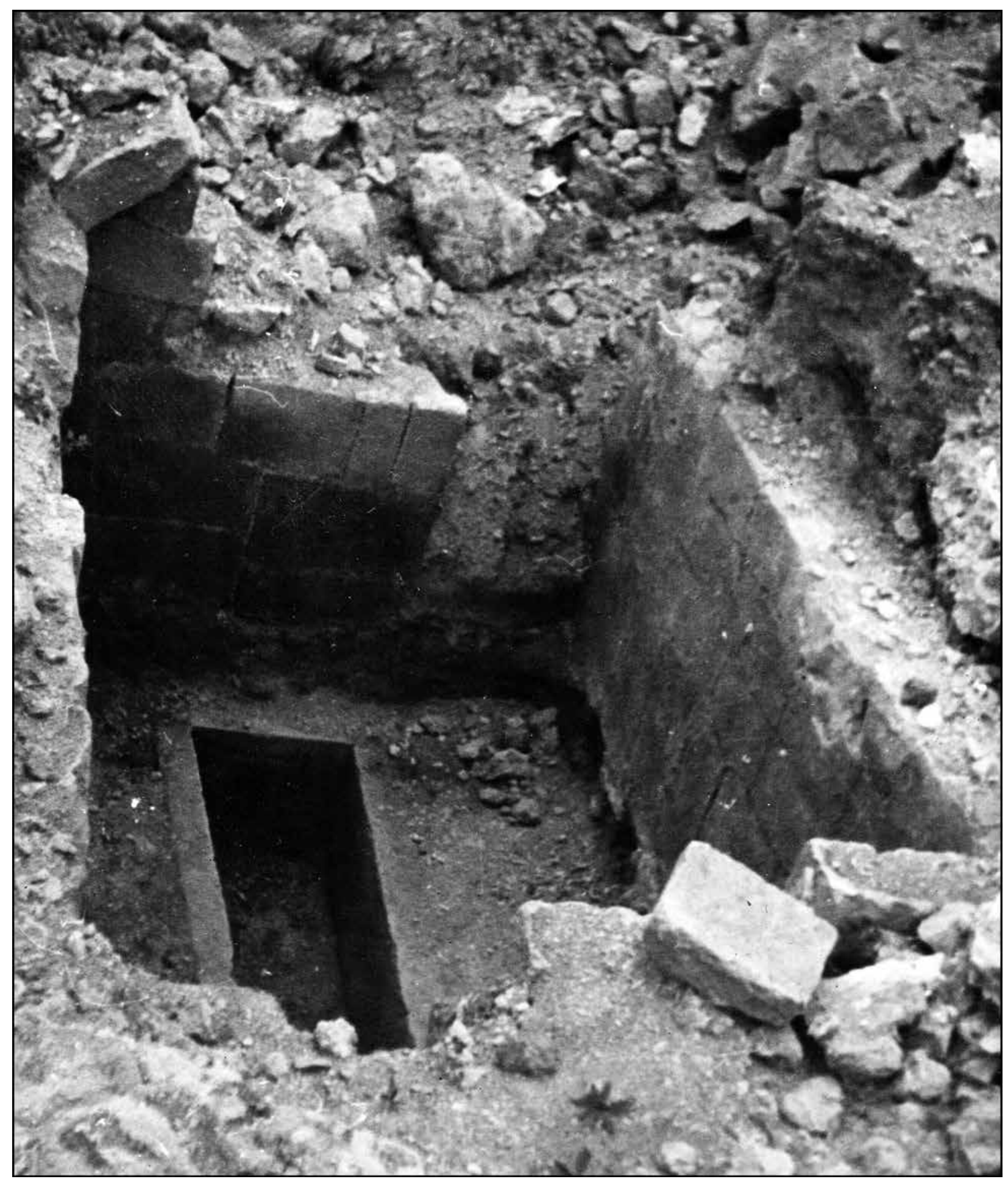

1. kép. Eger. A székesegyház hosszházának nyugati részén, a főhajó középtengelyében 1937 januárjában feltárt sírkamra egykorú felvétele (Forster Központ Fotótár, poz. ltsz. 21155)

Fig. 1. Eger. Archival photo of the burial chamber uncovered in the main axis of the nave in the western part of the cathedral's longhouse in January 1937 (Forster Centre, Photo Archives, inv. no. 21155) 


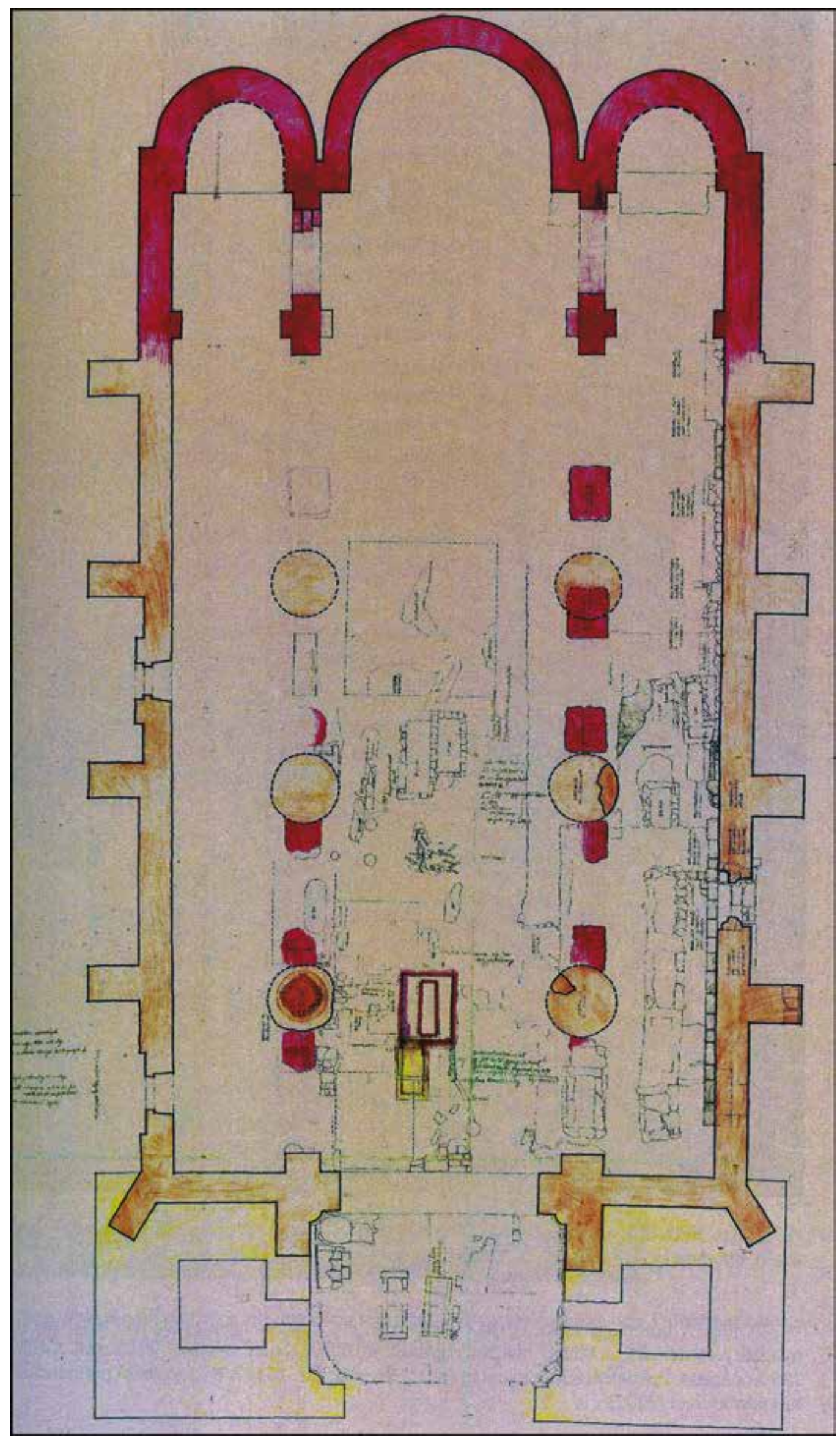




\begin{abstract}
2. kép. Eger. A középkori székesegyház 12. századi eredetú szentélyének és hosszházának alaprajza (a déli kápolnasor és a nyugati rész Árpád-kori maradványai nélkül) a főhajó nyugati részének közepén feltárt sírkamra jelzésével (KOZÁK KÁROLY DOK. 1969, Forster Központ Tervtár, ltsz. 25587, R1 nyomán), a szerző periodizációjával és kiegészítéseivel; vörös: 12. századi és kora 13. századi maradványok; narancs: az Árpád-kori előzmények nyomán épült hosszház, 13. század vége-kora 14. század; sárga: nyugati toronypár, 14. század dereka
\end{abstract}

Fig. 2. Eger. Plan of the 12th-century sanctuary and longhouse of the medieval cathedral (without the southern chapels and the Árpádian Age remains of the western part), and the indication of the burial chamber in the middle of the main nave's western part (after KOZÁK KÁROLY DOK. 1969, Forster Centre, Archive of Plans and Blueprints, inv. no. 25587, R1), complemented with the author's periodisation and modifications. Red: 12th-century and early 13th-century remains; orange: the longhouse built on Árpádian Age antecedents, late 13th-early 14th century; yellow: the western towers, mid-14th century

gelyében a kapu felóli harmadban egy sírkamrára bukkantunk, amelynek fenekébe volt a sír beeresztve. Ez valaha fekete, fehér és piros márvánnyal volt burkolva. A sírgödör is márvánnyal volt kirakva. Itt is ki voltak szórva a csontok a sírgödörből. A márvány burkolatot lefejtették, a sírkamra tetejét elpusztították, mert egy alapfalat húztak rajta keresztül. Ebben a sírkamrában találtunk egy román kettős oszlopocskához való lábazatkövet és a román templom egyik oszlopdarabját (egy és fél méter hosszú, kb. harmincöt centiméter átméröjû). Annak, hogy ez a sírkamra Árpád-kori volna, ellentmond az a körülmény, hogy a sírkamra teteje pontosan a XVI. századi padlószint alatt vonul el. A sírkamrán ajtó volt, ajtóvasalásnak nyoma nincsen, kifelé vezető lépcsőfokok nem voltak, tehát valószínúleg a sírkamra ajtaja egy kőlappal volt bezárva. A székesegyház területét a XIII. századi koragót szinten planíroztuk. A sírkamrában talált csontok közül kiválogattuk azokat, amelyek vörhenyes árnyalatúak voltak. A sírgödör vastartalmú darázskó homokba volt süllyesztve és úgy gondoljuk, hogy ezek a csontok feküdtek a sírgödörben. Leletek egy elhajlított rézpléh és egy kis rézabroncs darabka." 34

A sírkamráról a Múemlékek Országos Bizottsága számára a feltárással egykorúan forrásértékú fényképfelvétel is készült, amely a fenti jelentések nyomán vált azonosíthatóvá a középkori székesegyházra vonatkozó archív fényképek között (1. kép). ${ }^{35} \mathrm{Ez}$ a fényképfelvétel - készítője egyelőre ismeretlen - délkelet felől mutatja a kelet-nyugati irányban nyújtott téglalap alaprajzú s középrészén egy ennek megfelelő tájolású sírhelyet magában foglaló sírkamrát. Az építmény kváderfalazatú, délnyugati szögletében szegmensívú boltozat indításának legalsó ré-

34 Forster Központ, Tudományos Irattár, MOB 1937/152. sz. Az 1937. március 7-én kelt iratból kiemelt részt a feltárt maradványok jelentőségére való tekintettel és összehasonlításul az ásatási naplóban foglaltakhoz idézném.

35 Forster Központ, Fotótár, poz. 1tsz. 21155. Azonosításához: HAVASI 2004, 43. tegköve s alatta e helyütt a boltozat homlokívéig fennmaradt kváderfal részlete látható. A nyugati fal észak felé eső végén törmelékkel feltöltődött bejárati nyílás maradványa bontakozik ki. A sírkamra északi oldalfala, valamint keleti falának északi része a falkorona magasságáig állt. A felvételen is jól érzékelhető - főként a bejárati nyílás és az északi fal töve mellett kivehető nyomok kapcsán -, hogy a kamra alapozását, illetve padlóját a feltárás alkalmával vagy talán már egy jóval korábbi „kutatás” során áttörték. Az ásatási naplóban mellékelt vázlatrajz szerint a sírkamra a hosszház középrészén, a távolságadatok szerint annak nyugati felében helyezkedett el. A sírkamra belvilágának a naplóban rögzített méretei a következők:36 a nyugati és keleti homlokfala egyaránt $197 \mathrm{~cm}$, az északi fala $296 \mathrm{~cm}$, a déli pedig $263 \mathrm{~cm}$ hosszúságú, a nyílás szélessége 57 $\mathrm{cm}$. A sírkamra magasságaként padlószintjétől(?) $186 \mathrm{~cm}$-t mértek. A naplóban kriptának nevezett sírhely szélesebb nyugati oldala $58 \mathrm{~cm}$, a keleti $45 \mathrm{~cm}$, illetve hossza $202 \mathrm{~cm}$. Ezt a meglehetősen igényes kialakítású sírkamrát a feltárásakor elsősorban az építmény leleteire, a 16. századi padlószinthez (is) igazodó lezárására, valamint kvádereinek kőanyagára és építési technikájára hivatkozva - a 15. század második feléből valóként határozták meg.

Ami a keltezéshez alapul vett leletanyagot illeti, a beszámolók szerint a sírkamra betöltéséből késő gótikus és román kori faragványok kerültek elő, melyek az emlék késő középkort követő pusztulására vallanak; valószínúleg mindez nem lehetett független a székesegyház 16. század közepi romlásnak indulásától. A sírkamra fennállásának (építésének, használatának) és pusztulásának menetéhez és közelebbi datálásához járulhatnának hozzá - a pontos lelőhelyek és rétegviszonyok ismeretében - a betöltéséból és közvetlen környékéről előkerült pénzleletek, úgymint a Mátyás korára valló két pénz s egy

36 LÉNÁRT 1987, 462, 37/a-b kép. 


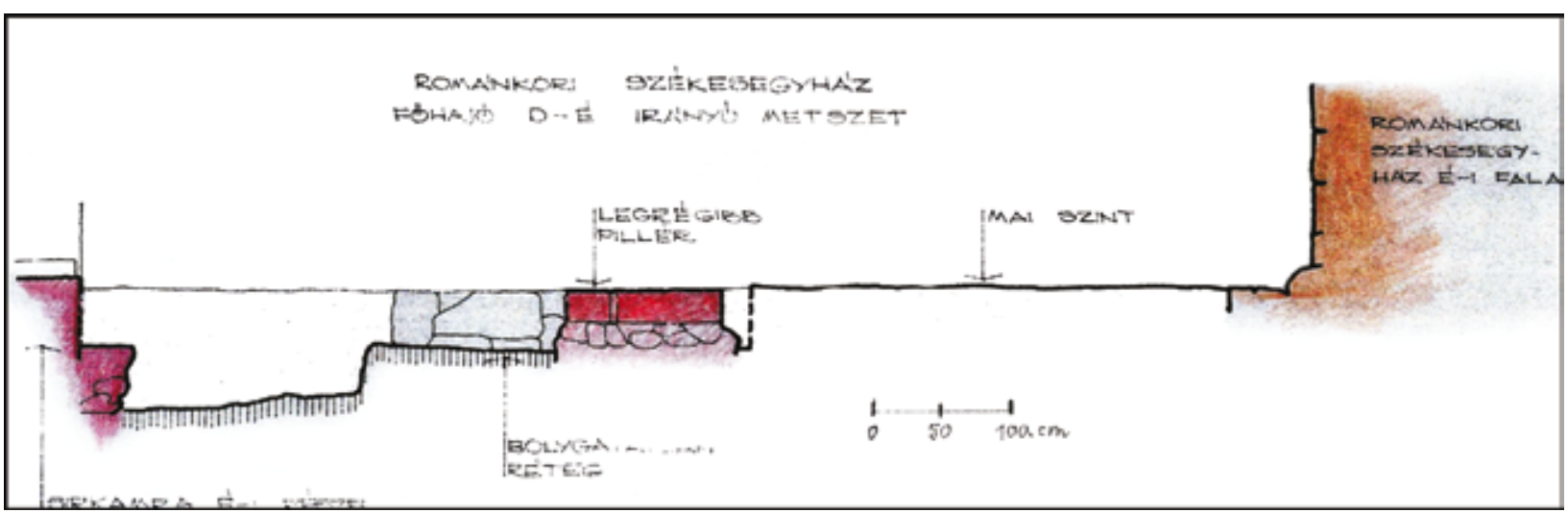

3. kép. Eger. A székesegyház északi mellékhajójának nyugati vége. Észak-déli metszet a román kori északnyugati pillér vonalában, baloldalt a sírkamra északnyugati sarkával (KOZÁK KÁROLY DOK. 1969, Forster Központ Tervtár, ltsz. 255578 R6 nyomán), a szerző periodizációjával; vörös: 12. század-kora 13. század; narancs: késő 13. század-kora 14. század

Fig. 3. Eger. Western end of the cathedral's northern side-nave. North-south section in line with the north-western Romanesque pillar, with the burial chamber's north-western corner (after KOZÁK KÁROLY DoK. 1969, Forster Centre, Archive of Plans and Blueprints, inv. no. 255578, R6), complemented with the author's periodisation. Red: 12th-early 13th century; orange: late 13th-early 14 th century

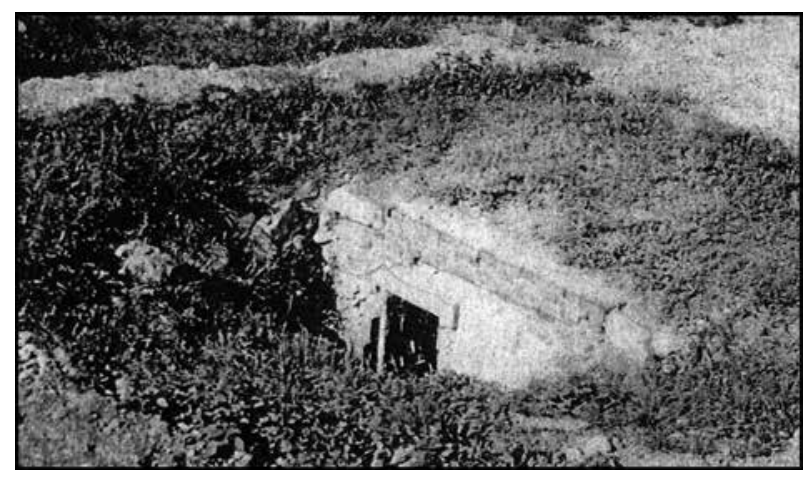

4. kép. Eger. A sírkamra helyreállított nyugati része délnyugat felől a székesegyház ásatásainak befejezése után, 1938ban. (Forster Központ Fotótár, poz. ltsz. 27135 [A.641/1938])

Fig. 4. Eger. The burial chamber's restored western part from the south-west in 1938, following the completion of the excavation (Forster Centre, Photo Archives, inv. no. 27135 [A.641/1938])

"II. András korára gyanús friesachi dénár". ${ }^{37}$ Azonban a korabeli felvétel precíz kváderfalú és boltozott sírkamráját, illetve az ennek előkelő fekvéséről tanúskodó adatokat szemlélve egy korábbi építmény tiszteletteljes-praktikus késó középkori megtartására vonatkozó feltételezés inkább megfogalmazódhatna, mint egy a késő

37 LÉNÁRT 1987, 460-481. A 1930-as évekbeli székesegyház-ásatásokon előkerült pénzleletekről vezetett napló eddig sajnos ismeretlen, a sírkamra kapcsán leírt pénzleletek csak említésből (fizikai valójukban nem) ismertek. Ugyanakkor nehezíti a helyzetet s ezzel az épületmaradványok, részletek datálásának legfontosabb (egzakt) régészeti érve veszik el, hogy a pénzeket legtöbbször nem lehet pontosan réteghez, egyéb építészeti, régészeti jelenséghez kötni. Az említett késő gótikus és román kori faragványok nem vagy csak bizonytalanul azonosíthatók (talán az ikeroszlop-lábazat ilyen) a székesegyház faragottkő-emlékanyagában. középkorban újonnan létesítetté. Épp ezért is szükséges az építmény késő középkorból való eredeztetésének kérdésével kapcsolatos történeti adatoknál is néhány sorral idózni. A 15. század derekának és második felének méltóságuk viselése közben elhunyt egri püspökei közül hármat temethettek el a székesegyházban. Közülük azonban csak Rozgonyi Péter (1425-1438) és Nagylucsei (Dóczy) Orbán (1486-1492) sírhelyével és síremlékével kapcsolatosan maradtak fenn adatok, valamint írott források. Rozgonyi síremlékét Verancsics Antal püspök - amint az egy leveléből kitúnik - az 1560-as évek elején megújíttatta, nyughelye feltételezhetóen az általa

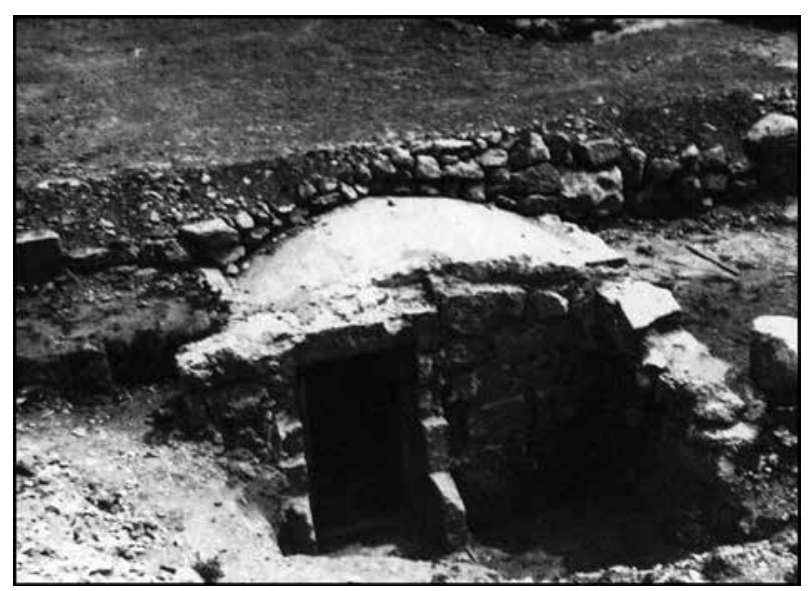

5. kép. Eger. A sírkamra nyugati falának külső oldala északnyugat felől az ásatásokat követő tereprendezés közben 1969-ben. (KozÁK KÁROLY DOK. 1969, 23. tábla, 3. kép nyomán)

Fig. 5. Eger. Outer face of the burial chamber's western wall in 1969, during the landscaping after the excavation (after KozÁK KÁroly DoK. 1969, Pl. 23, Fig. 3) 


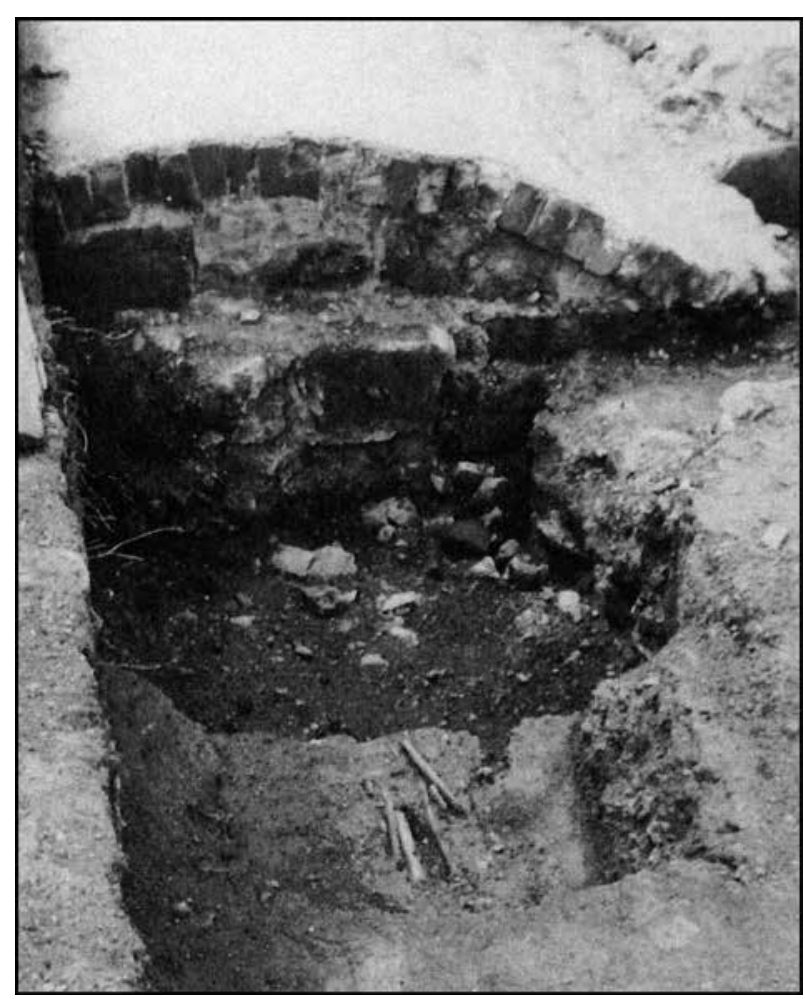

6. kép. Eger. Ásatás a fóhajóban a sírkamra keleti falának külső oldalán 1969-ben kelet felől (KOZÁK KÁROLY DOK. 1969, 17. tábla, 3. nyomán)

Fig. 6. Eger. Excavation by the outer face of the burial chamber's eastern wall in the main nave in 1969, from the east (after KozÁK KÁroly DoK. 1969, Pl. 17, Fig. 3)

újjáalapított, Szúz Máriának szentelt prépostság - egykor a székesegyház déli oldalán állott - kápolnájában lehetett. ${ }^{38}$ Orbán püspök sírhelyéhez már eddig is jóval több kérdés és problémafelvetés füződött. ${ }^{39} 1492$. augusztus 28 -án Budán kelt az a Fodor István szerémi püspök által kiállíttatott oklevél, amely az egri káptalannak juttatott megfeleló ingatlanok és a székesegyháznak adományozott felszerelési tárgyak, liturgikus kellékek fejében rendelkezik a nem sokkal korábban elhunyt nagybátyja, Orbán egri püspök lelki üdvéért mondandó misékről. ${ }^{40} \mathrm{Az}$ adományozó

38 Ez a székesegyház déli oldalán az ún. K4 kápolnával azonosítható. Erről bővebben: HAVASI 2006, 101-102; HAVASI 2011, 32-42. Verancsics Antal 1563 júliusában kelt levelét lásd MHH 1870, 27-28; DÉTSHY 1964, 7.

39 KozÁK-Sedlmayr 1987, no. 84, 25, 50-51. kép. A püspök síremlékével azonosítható vörösmárvány tumba töredékeinek összefoglaló, részletes ismertetése Lóvei Pál kéziratos sírkőkorpuszának egri tételei között található. Lővei Pálnak az egri kőtárak középkori sírköveit tárgyaló kéziratos katalógusáért ezúton is köszönettel tartozom. Továbbá: LóvEI 2010, 435-436; Újabban: LÓveI-WeIsz 2016, 234, 263, 10-11. kép.

40 Heves Megyei Levéltár, Mohács előtti oklevelek, 360. (Korábbi jelzete: Egri Érseki Levéltár, Numerus 9. divisio 2. f. 2. n. 1.) Kivonata és a jelen idézet forrása: PATAKI é. n., no. 57. „...duos calices argenteos auratos, duas phialas vel ampullas

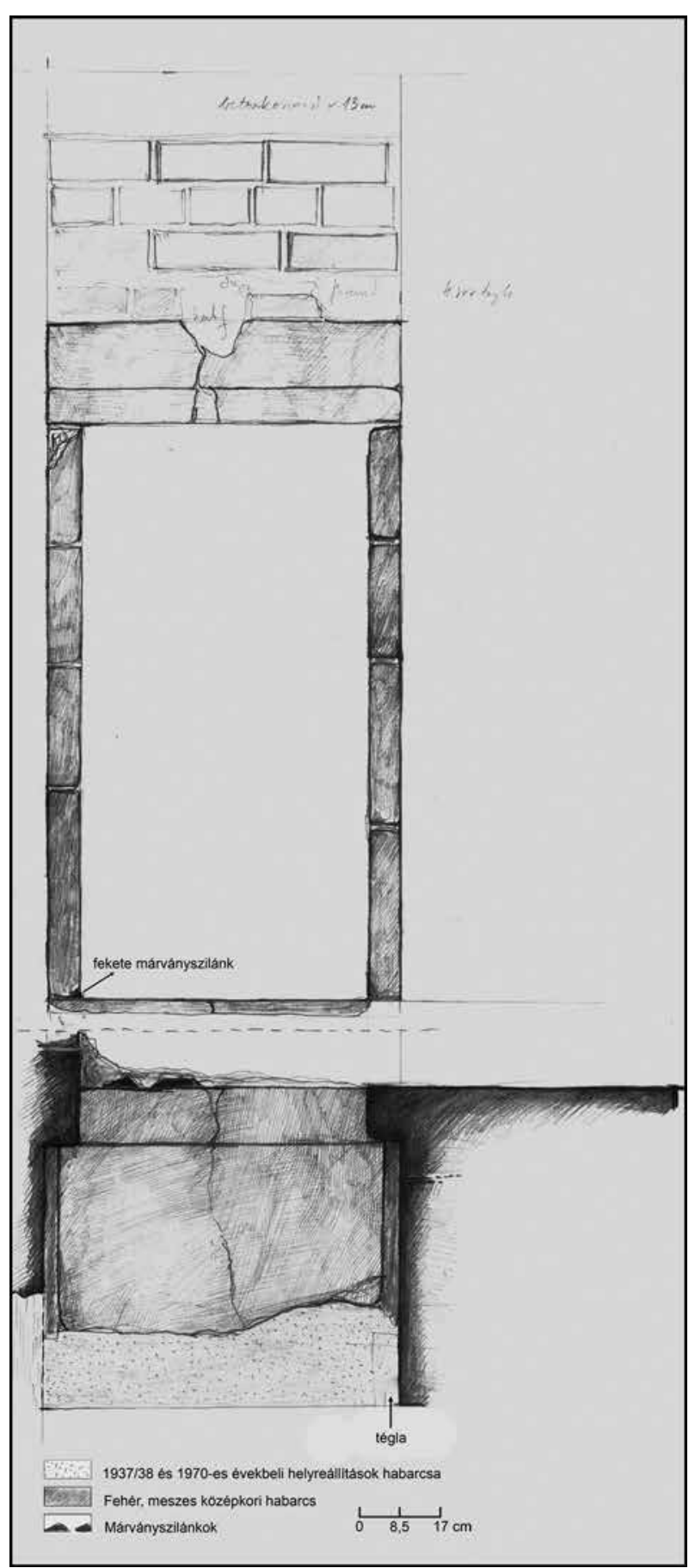

7. kép. Eger. A sírkamra nyugati része a bejárattal. Alaprajz és nézet nyugat felól (rajz: Havasi K., 2004. szeptember)

Fig. 7. Eger. The burial chamber's western part with the entrance. Plan and view from the west (drawing: K. Havasi, September 2004)

argenteas, unum Agnus Dei argentum et auratum, que quidem omnia octo marcarum sunt ponderis. Item librum missarum, quem missale vocant, in membranis impressum et exornatum minio cum insignibus eiusdem domini episcopi, casulas vel planetas tres sericeas ex veluto rubro et nigro et damasco albo et tria indumenta altaris de eadem colore pietissime donavit..." 

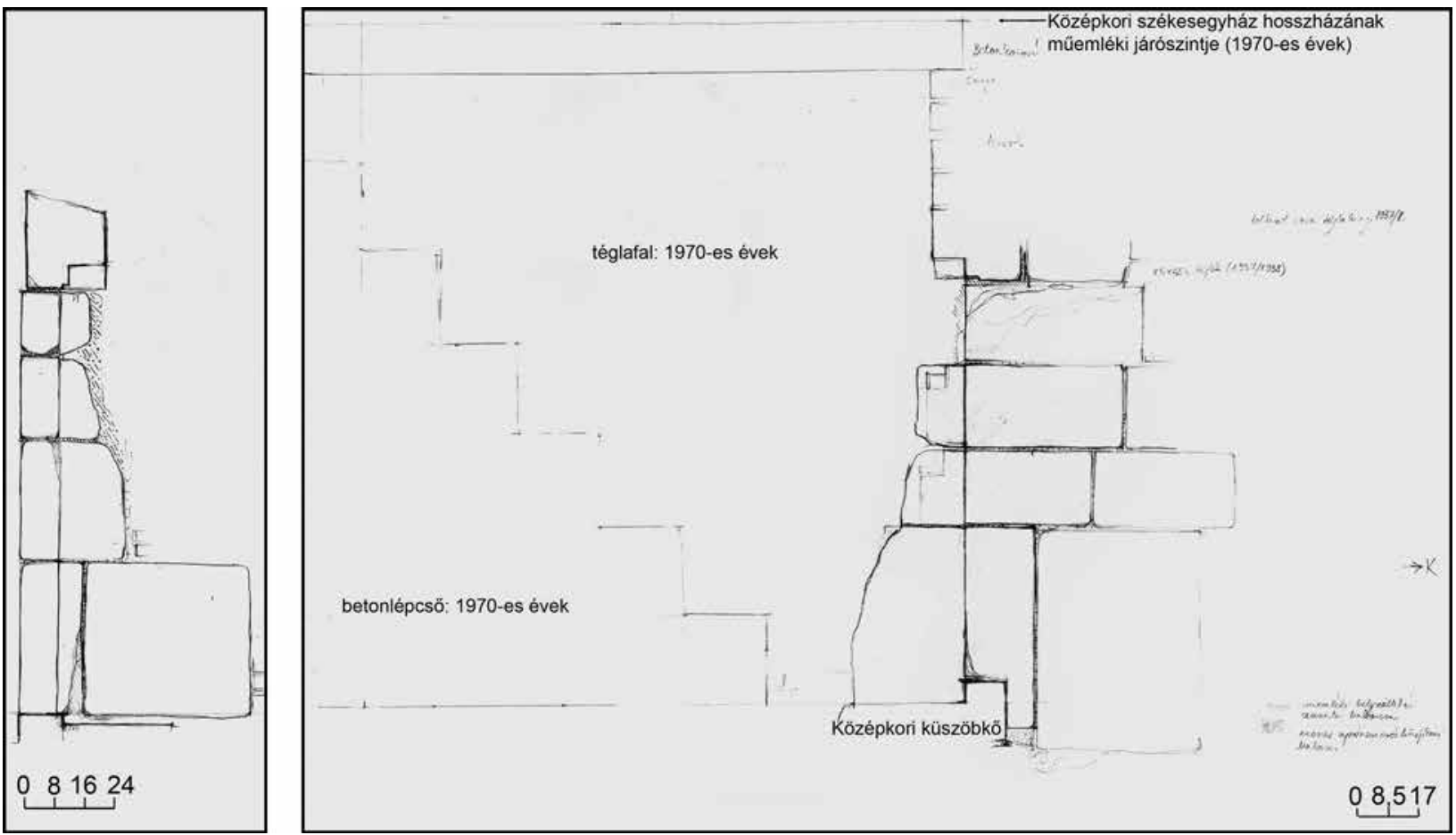

8. kép. Eger. A sírkamra nyugati oldala, oldalnézet dél felé a bejárat jobb oldali részével és az azzal kötésben lévő lépcsőlejárat falának maradványával (rajz: Havasi K., 2004. szeptember)

Fig. 8. Eger. The burial chamber's western side, side-view to the south with the entrance's right side and the remains of the associated flight of steps (drawing: K. Havasi, September 2004)

9. kép. Eger. A sírkamra nyugati oldala, oldalnézet észak felé a bejárat bal oldali részével és a lépcsőlejárat falának azzal kötésben lévő maradványával, valamint a rekonstruált lépcsőlejárat jelzésével (rajz: Havasi K., 2004. szeptember)

Fig. 9. Eger. The burial chamber's western side, side-view to the north with the entrance's left side and the remains of the wall of the associated flight of steps and the indication of the reconstructed steps (drawing: K. Havasi, September 2004)

kívánsága szerint az emlékmisék az egyház Szent Kereszt-oltáránál vagy más, a püspök síremlékéhez közelebb lévő oltárnál mondandók el. ${ }^{41}$ Utóbb a forrás ezen kitételéből a püspöknek a Szent Kereszt-oltára elé vagy annak közelébe való temetésére vonatkozó megállapítás lett. ${ }^{42}$ Az ásatások után kibontakozó alaprajz ismeretében az oltár és a temetkezés helyét Détshy Mihály jelölte meg a templomépület „régi” részében (ez 1500 körül a hosszházat jelentette), ${ }^{43}$ míg

41 „....in eadem ecclesia Agriensi, ubi scilicet corpus (ipsius) domini Urbani episcopi in monumento sumptuoso, atque aereo per eundem dominum episcopum Syrmiensem suis sumptibus propriis exstructo humatum esset et super altari sancte Crucis in eadem ecclesia Agriensi fundato aut altaro prescripto sepulchro magis propinquo celebrari facere debeant..." IPOLYI 1865, 139-140, 2-3. jegyzet.

42 SснмітTH II. 1768, 139-140. „...tumulum nactus Agriae in sacris aedibus S. Joannis Apostoli et Evangelistae ante aram Sanctae Crucis".

43 DÉTshy 1964, 1, 2, 6, 42, 60-62. jegyzet. Détshy Mihály a Szent Kereszt oltártitulusból - az oltár helyét ő egyébként az északi mellékhajóban feltételezte - következtetett arra, hogy Orbán püspök a székesegyház „régi" részébe temetkezett. SuGÁR más kutatások az egri Szent Kereszt-oltár helyét a párhuzamok ${ }^{44}$ és az 1509-ben nyomtatott formában kiadott Ordinarius-nak a Szent Keresztoltárra vonatkozó sorai nyomán a főhajó középrészén, a szentélyt a laikusok terétől elválasztó „rekesztő" előtt feltételezték. ${ }^{45} \mathrm{Az}$ oklevélben

1984, 183-190, különösen: 187-188; KoZÁK-SEdLMAYR 1987, 25, Kat. no. 84, 50. kép.

44 A Szent Kereszt-oltároknak a liturgia hozzá füződő cselekményei révén kitüntetett helyzete a középkori templomok testén belül ismert; vizsgálatuk több tanulmány tárgya volt. Ezen oltárhoz kötődő liturgikus tartalmaknak és a funkciónak köszönhetően a szertartásrendet hagyományozó szövegekben a liturgia vonatkozó cselekményeit leíró kontextus kíséretében helyzetének megjelölése, körülírása viszonylag gyakran fordul elő. Ezekből a fennmaradt emlékanyaggal összefüggésben az oltárnak a 11-12. század folyamán a székesegyházak testén belül (is) rögzülő s következetessé váló, rendszerint a kórus fóhajó felóli homlokzatával kapcsolatban megjelölt helye túnik ki. HumanN 1893, 76-77, 82; OswaLd 1969; MöвIUS 1983, 32-41; То́тн М. 1987, 99-108.

45 Az oltár első ismert okleveles említése 1359. május 19-ről maradt fenn. Erről: DÉTSHY 1964. 1, 10. jegyzet. MEZEY 1971, 113; MAROSI 1984, 207-213; 1986, 103-104. Marosi Ernő az Ordinarius vonatkozó, az esztergomi szertartásrenddel össze- 


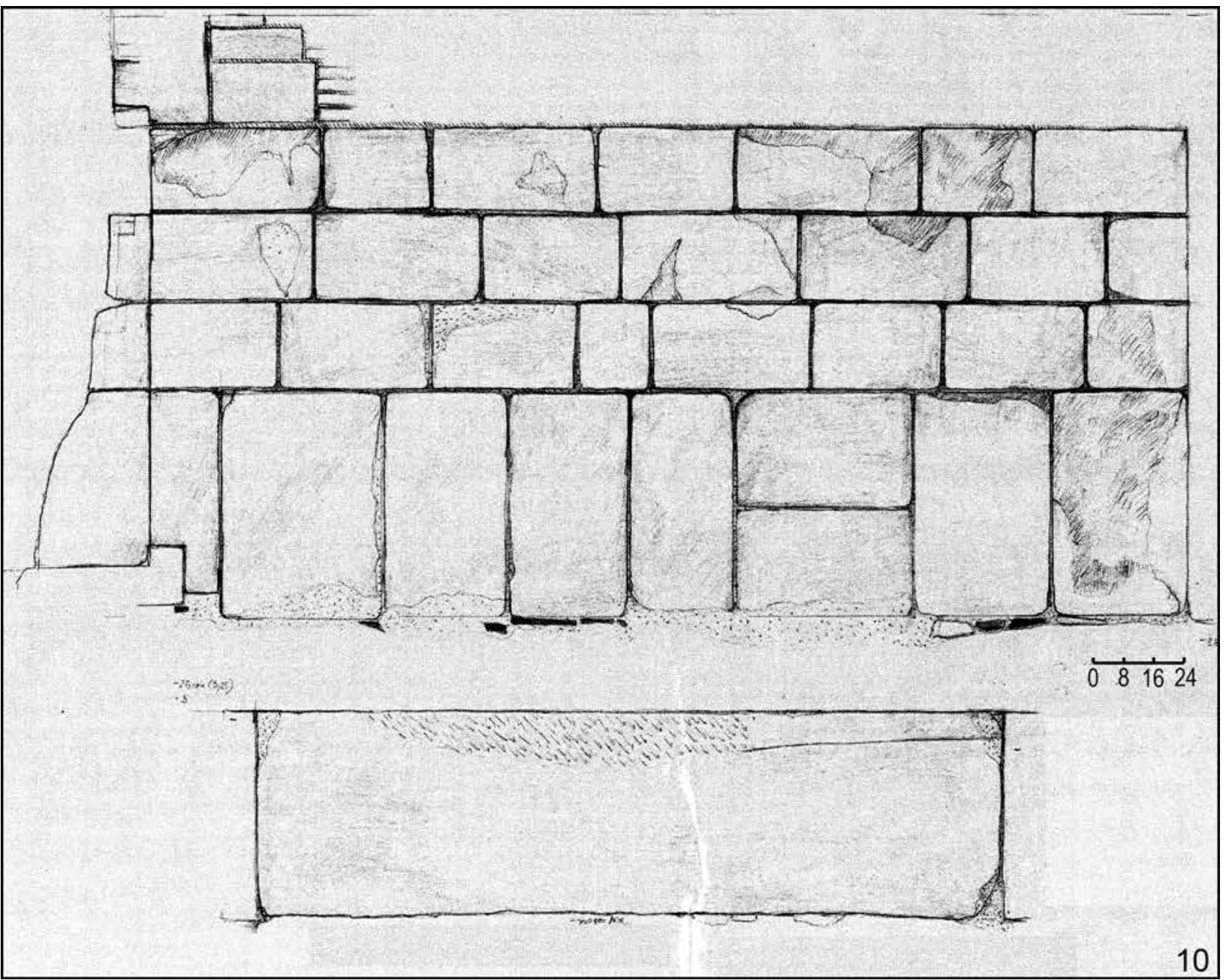

10. kép. Eger. A sírkamra északi falának belső nézete baloldalt a bejárat metszetével és a lépcső északi falából fennmaradt részlettel, valamint a sírláda hosszmetszetével (rajz: Havasi K., 2004. szeptember)

Fig. 10. Eger. Inner face of the burial chamber's northern wall with the section of the entrance, the surviving portion of the flight of steps' northern wall and the longitudinal section of the chest tomb (drawing: K. Havasi, September 2004)

vetett passzusai nyomán feltételezte, hogy „az egri székesegyház lettnerének nyugati oldalán a Szent Kereszt oltár állt". A Szent Kereszt-oltár említései az Ordinariusban: In nativitas Domini: in matutinis: „....item post ultimam homeliam chorus stet ad duas partes cantantes Responsorium... iterum redeant ad chorum. Deinde statim per duos ad id tabulatos cantetur evangelium. Finito evangelio duo iuvenes supra altare sancte crucis cantant antiph. O regem coeli. Postes duo similiter in medio pulpito cantent...". In festo pasche: in secundis vesperis: „....deinde processio revertitur et stat ad duas partes in medio ecclesie cantando resp. Xristus resurgens. Et versum. Dicant nunc iudei canunt choratores ante altare s. crucis versis faciebus ad processionem. Et dum in versu canitur. Aut sepultum reddant. Processio intrat chorum cantando...". Inventio sancte crucis: in missa: „...et totum officium misse peragitur in altari sancte srucis... unus ex diaconibus de sacristia sub parvo velo exportat crucem: choratoribus precedentibus et cantantibus hymnum [...] Deinde missans vertit se ad populum cum sancta cruce incipit canere offertorium..." ORDINARIUS 14, 72-73, illetve 149; KovÁcs B. 1987, 71; DobSZAY 2000, 271 (43. jegyzet), 280, $369,386-387,410-411$.
Orbán püspök sírhelyével és síremlékével kapcsolatban - melyhez vörösmárvány tumba és bronzból öntött fedlap tartozhatott - a Szent Kereszt-oltár közelségét sejtető fordulat és nem a kettő közvetlen összefüggését megadó helyhatározás szerepel. Továbbá, figyelembe véve egy a feltárója által késő középkori püspöksírként meghatározott, a hosszház északi pillérsorának vonalában nyugatról második és harmadik pillér közé eső temetkezést, ${ }^{46}$ valamint egy másik közeli (a nyugatról második északi pillér főhajó felőli oldalán feltárt), ,,aranyozott szövetmaradványo-

46 E sírra vonatkozóan: KOZÁK KÁROLY DOK. 1968, 23. és 26. rajz. Az ásatási napló szövegében nem esik szó a kérdéses sírról. A dokumentáció a Dobó István Vármúzeum Régészeti Adattárában oorzött példányán: 353. 26. rajz (ún. „7. sír”). 


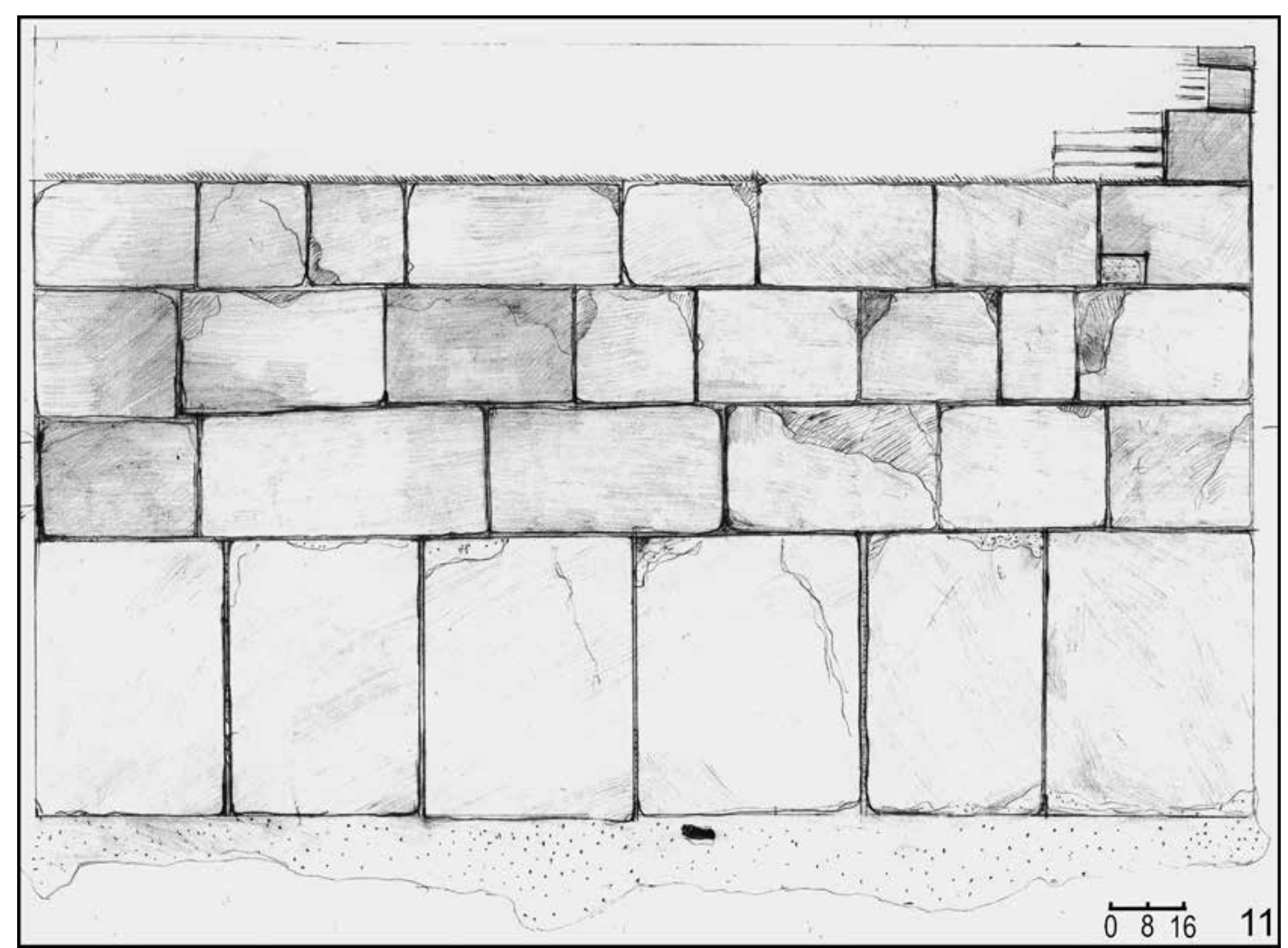

11. kép. Eger. A sírkamra déli falának belső nézete (rajz: Havasi K., 2004. augusztus)

Fig. 11. Eger. Inner face of the burial chamber's southern wall (drawing: K. Havasi, August 2004)

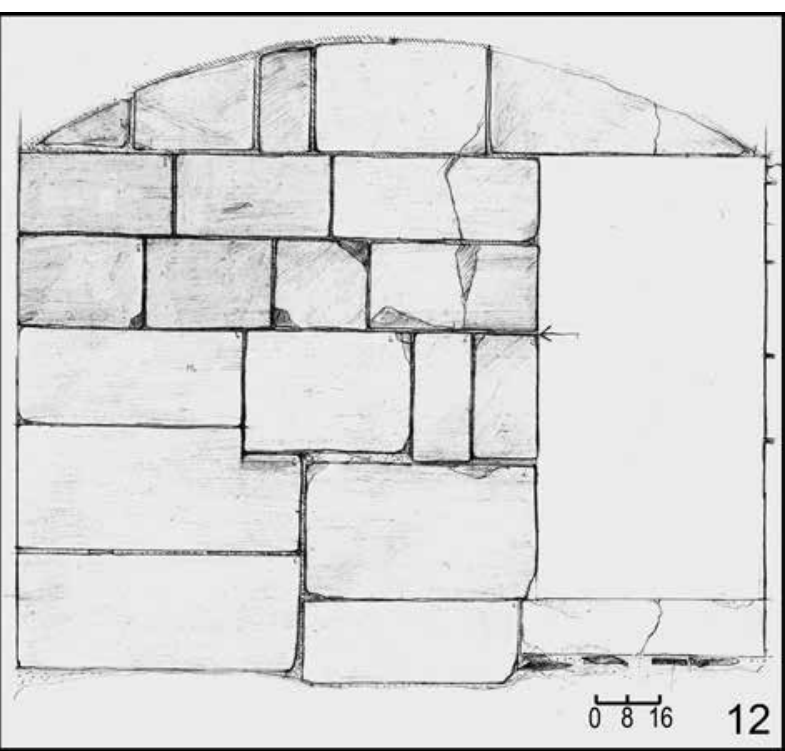

12. kép. Eger. A sírkamra nyugati falának belső (kelet felőli) nézete (rajz: Havasi K., 2006. szeptember)

Fig. 12. Eger. View of the inner face of the burial chamber's western wall, from the east (drawing: K. Havasi, September 2006)

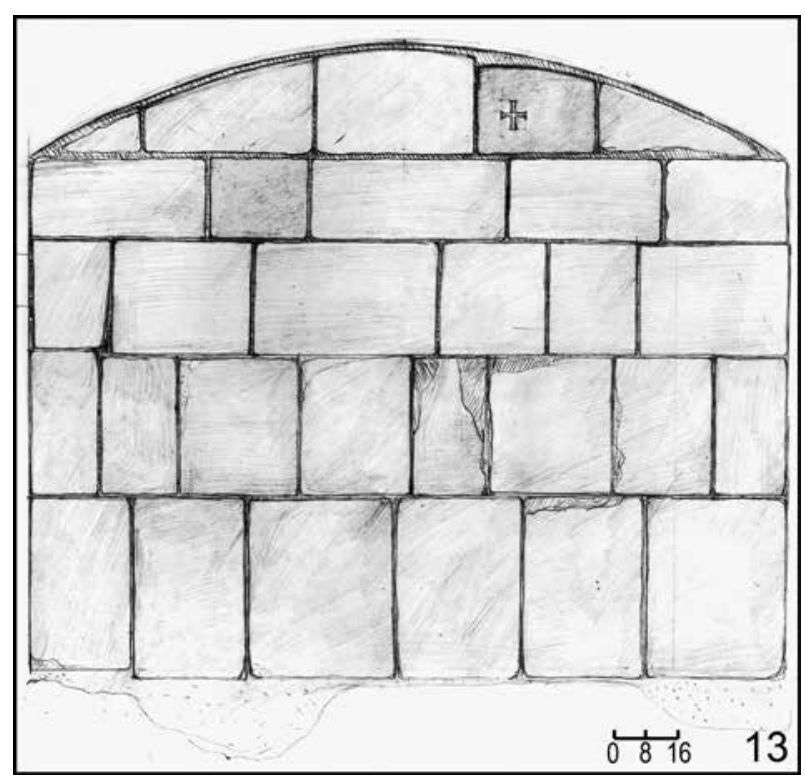

13. kép. Eger. A sírkamra keleti falának belső (nyugat felőli) nézete (rajz: Havasi K., 2006. szeptember)

Fig. 13. Eger. View of the inner face of the burial chamber's eastern wall, from the west (drawing: K. Havasi, September 2006) 


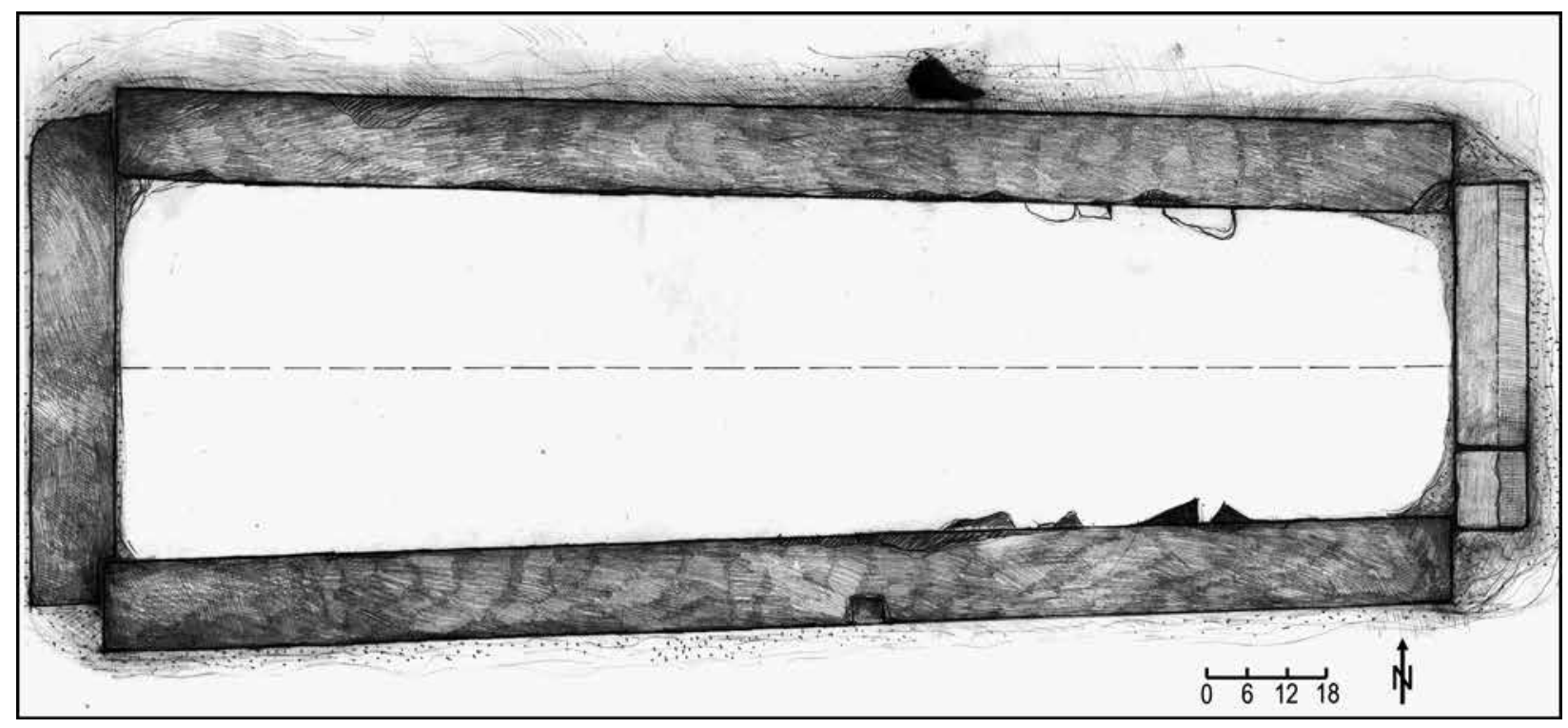

14. kép. Eger. A sírkamra tengelyében fekvő sírláda felülnézete (rajz: Havasi K., 2004. szeptember)

Fig. 14. Eger. Top view of the chest tomb set in the burial chamber's axis (drawing: K. Havasi, September 2004)

kat" tartalmazó sírt, ${ }^{47}$ Orbán püspök közvetlenül eme főhajóban feltételezett oltár elé való eltemetése valószínútlennek túnik, mint ahogyan az előkelő fekvésú sírkamrába temetkező személy Orbán püspökkel való azonosítása is felettébb kétséges lenne. Megjegyzendő azonban, hogy az előbb említett, a gótikus északi pillérsor vonalában feltárt püspöki sír a róla fennmaradt rajz szerint éppolyan egyszerú kiképzésû, nem sokkal a padlószint alatt kialakított, faragott kövekből falazott sírhely volt, mint az, amelyiket a nyugati toronypár közötti előcsarnok középtengelyében tártak fel 1974-ben. Ez utóbbi pedig az egyetlen a székesegyházban feltárt temetkezések között, melyet leletei alapján is hitelesen püspök személyéhez, mégpedig az 1361-ben elhunyt Dörögdi Miklóséhoz lehetett kapcsolni. ${ }^{48}$

47 KOZÁK KÁROLY DOK. 1969, 24-25. „A románkori székesegyház főhajójának nagy szelvényében felmértük és felszedtük a 21. és 22. sz. sírokat, majd megkezdődött a föld visszatemetése. A 21. sz. sírban aranyozott szövetmaradvány került elő. [...] A románkori székesegyházban a második gótikus pillér mellett egy nagy kősír maradványa mutatkozott valamint egy ossarium - amelyben megtaláltuk a 21. sz. sír koponyatöredékeit rajta az aranyozott szövetdarabokkal." A sírok hosszházon belüli alaprajzi azonosításához vö. 28. jegyzet. Fontos lenne, ha még van rá mód, az ezen sírokból (és a többi bolygatatlan sírból) elókerült leletanyag részletes feldolgozása.

48 KozÁK KÁroly DOK. 1974, 49-50; KoZÁK 1981, 9, 20-21. kép; KoZÁK 1989, 5-7. Dörögdi sírjáról bővebben lásd korábbi irodalommal: HAVASI 2011, 61-68 (,,in transitu in medio" c. fejezet). A területet érintő hitelesító feltárásról: NAGY L. 2015, 92-98.

\section{A sírkamra}

A vizsgált sírkamra - helyreállított formájában napjainkban is fennáll a romterület alatt (1-25. kép). ${ }^{49} \mathrm{Az}$ építményt a fennmaradt délnyugati boltindítás szerint lapos, szegmensíves donga fedte. Jelenleg látható boltozata az eredeti indítás ívének figyelembevételével az 1938 táján készült, helytálló rekonstrukció. ${ }^{50}$ Ugyanekkor az építmény falainak kisebb hiányait eredeti, feltehetóen nagyobbrészt magából a sírkamrából kihullott kváderkövek visszaépítésével pótolták. ${ }^{51}$ A sírkamrához keskeny, a bejárati nyílással egyező szélességú, egyenes karú lépcső vezet le, amely-

49 Helyreállítására a jelek szerint még az 1930-as évek végén sor került. Lásd Forster Központ, Fotótár, poz. ltsz. 27135, 1938as évszámmal (itt: 4. kép). A fényképen az újraboltozott s vékony földréteggel fedett sírkamra kiszabadított nyugati homlokfala látható kívülről. A bejárati nyílást egyenes szemöldökkővel hidalták át, a falak felmenő részeinek hiányait pedig e külső oldalon téglával pótolták. A sírkamra helyszíni vizsgálataira és dokumentációjára nagyobbrészt a Lapidarium Hungaricum program (OTKA T.46188. sz., témavezetô: Lővei Pál) keretében 2003-2006 folyamán több alkalommal került sor, a munka konzulensei Tóth Sándor, Tóth Melinda, Marosi Ernő és Lővei Pál voltak. 2006-ban természettudományos vizsgálatok is megkezdődhettek. Mindezek folytatása kiemelkedően fontos lenne (lett volna).

50 A boltozat helyreállítása, kiegészítése téglából készült, kivéve a donga ívének nyugati kősorát, ahol a fennmaradt indítás részlete (a behullott?) kváderekből újrarakott kiegészítést kapott. Lásd még az előző jegyzetet.

51 Lényegében csak a két rövidebb oldalfal északnyugati, illetve délkeleti részén hiányoztak a boltozat vállvonala feletti kváderek. A visszaépített kváderek méretre, megmunkálásmódra az eredetileg is ott lévőkkel megegyezőnek túnnek. 


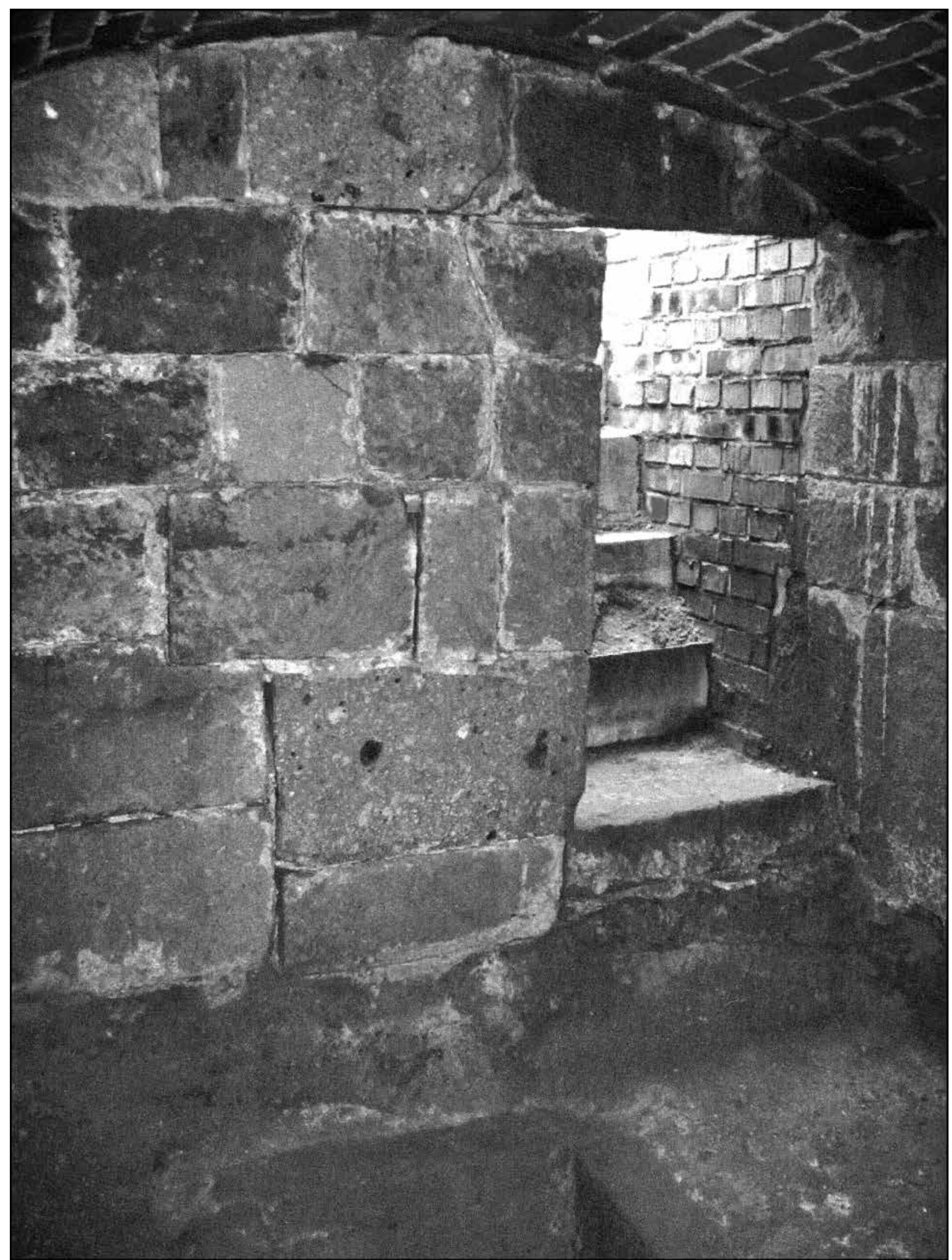

15. kép. Eger. A sírkamra belső, nyugati oldala a bejárattal délkelet felől (fotó: Havasi K., 2004. szeptember)

Fig. 15. Eger. Inner face of the burial chamber's western wall with the entrance, from the south-east (photo: K. Havasi, September 2004) 


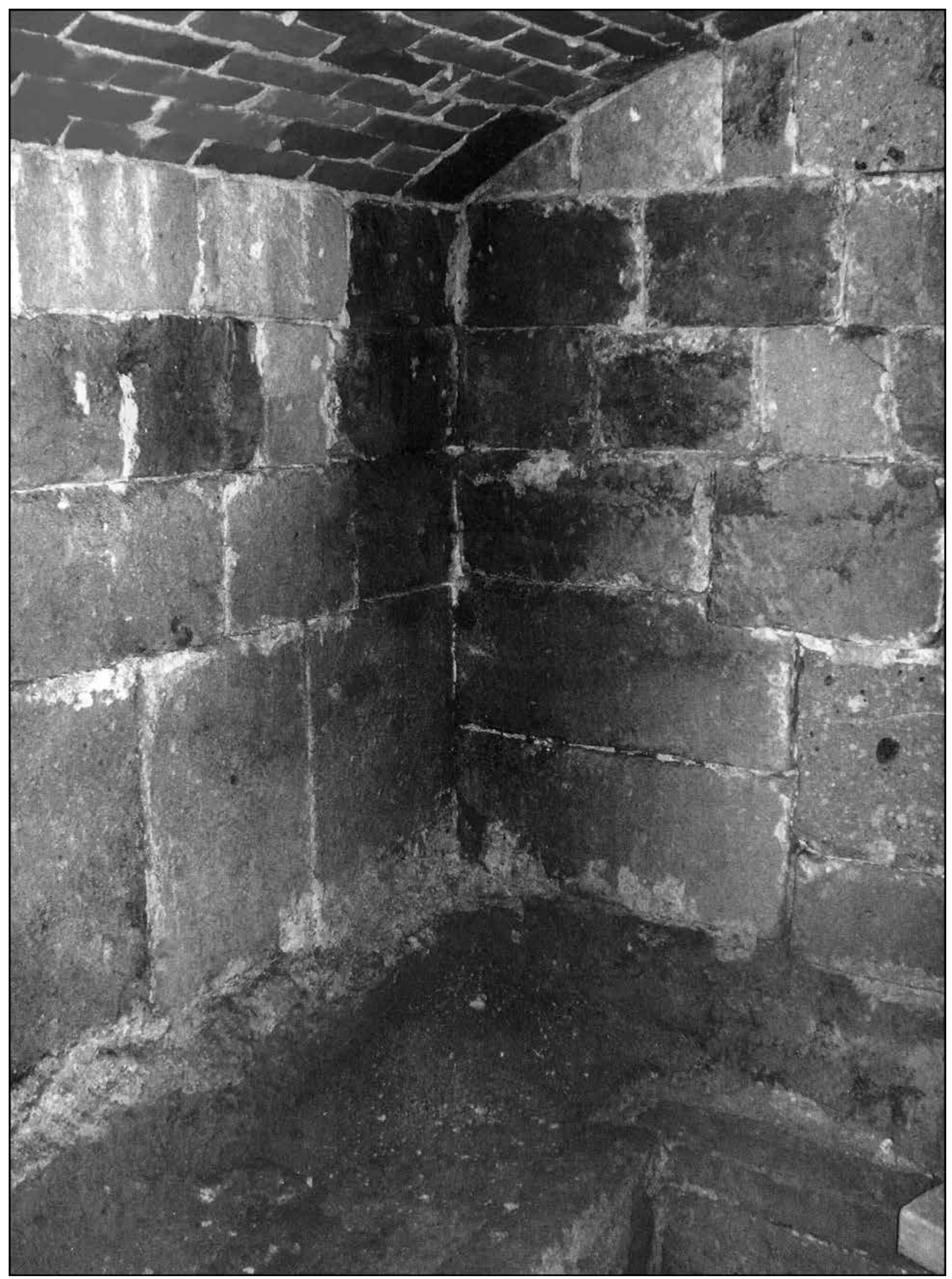

16. kép. Eger. A sírkamra belseje a délnyugati sarokkal, az in situ fellelt dongaboltozat-indítás, valamint a sírláda részletével (fotó: Havasi K., 2004. szeptember)

Fig. 16. Eger. The burial chamber's interior with the south-western corner, the in situ base of the barrel vault and a part of the chest tomb (photo: K. Havasi, September 2004) 


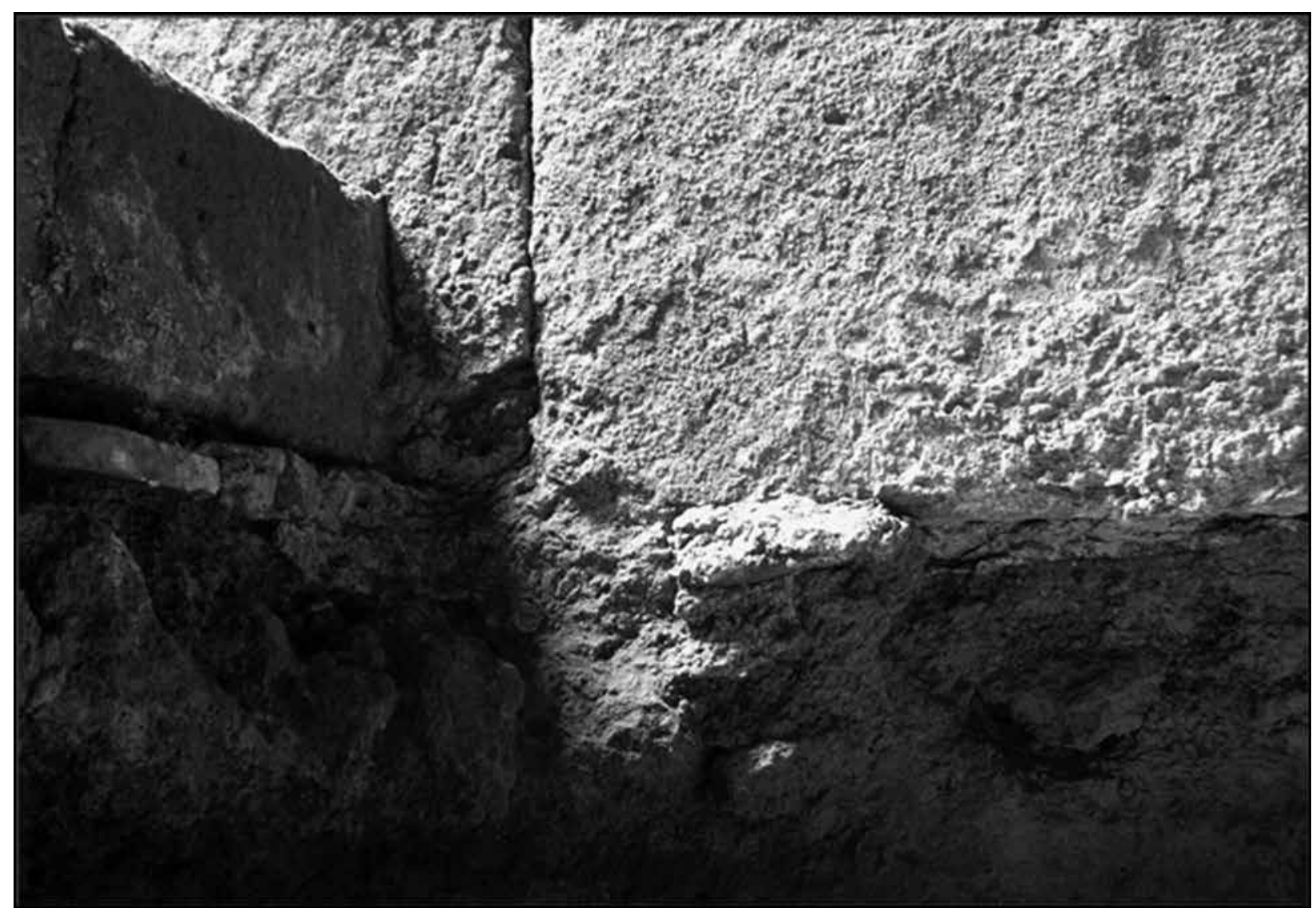

17. kép. Eger. A sírkamra küszöbkövének belső oldala, északnyugati sarok: az alapozás tetejére fektetett márványlapocskákkal (fotó: Havasi K., 2006. augusztus)

Fig. 17. Eger. Inner side of the burial chamber's threshold stone and the north-eastern corner with the marble plaques laid on top of the bedding (photo: K. Havasi, August 2006)

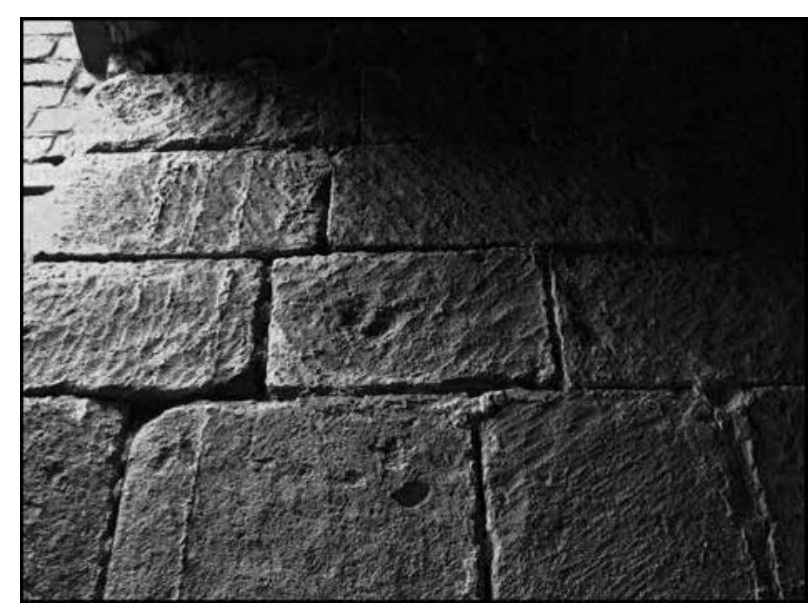

18. kép. Eger. Részlet a sírkamra északi faláról a kváderek felületi megmunkálásával (fotó: Havasi K., 2006. augusztus)

Fig. 18. Eger. Detail of the burial chamber's northern wall and the surface finish of the ashlars (photo: K. Havasi, August 2006)

nek ma csak a legalsó foka eredeti. A lépcső északi és déli oldalfalából a bejárati nyílással kötésben négy-négy sor felmenő részlet őrződött meg, az északi oldalfal a sírkamra északi falával egy vonalban épült fel $(1,5-6,16$. kép).

A világháború előtti ásatók ${ }^{52}$ megfigyelése szerint a finoman habarccsal borított felületú „kriptasír" valójában habarccsal összekötött kőlapokkal bélelt sírgödör, négy oldalán közel arasznyi vastagságú kőlapokból összeállított "sírláda”. Rövidebb oldalai két, illetve három elemból vannak összeállítva (14, 20-23. kép), míg a hosszanti oldalak egy-egy hatalmas kólapból állnak. A sírláda hosszanti oldalait alkotó nagyméretú kőlapok belső felületei fúrészeltek, talán ezeknek a megmunkálásmódból adódó aprószemcsés textúrája kelthette egykor a habarccsal borított felület benyomását. ${ }^{53}$ A sírhely oldalait bélelő kőlapokat

52 Az adattárakban fennmaradt rajzok és fényképek (2-3, 5-6. kép) tanúsága szerint a Kozák Károly vezetésével folytatott ásatások 1969-ben szintén érintették a sírkamrát és környezetét, azonban a vonatkozó ásatási jelentések és közlemények lényegében hallgatnak az objektumról.

53 És nem utolsósorban a kőlapok felületén a beázások következtében kicsapódó anyagok. Vö. a fószövegben fentebb idézett ásatási naplórészlettel (és 33-34. jegyzet). Persze az is lehetséges (bár kevésbé túnik valószínúnek, mivel semmi 
összekötő habarcs ugyanaz a fehéres színú, finomszemcsés, meszes anyag, mint amely a sírkamra felmenő falainak eredeti maradványainál megfigyelhető.

A sírkamra alaprajzilag a hosszház nyugati részében, körülbelül a nyugati pillérpár vonalában helyezkedik el. Nyugati fala az újjáépített gótikus hosszház nyugati falától nagyjából 5 méterre húzódik. A sírkamra ezen nyugati fala a hozzá vezető lépcsővel és a bejárattal a hosszház korábbi, román kori periódusában a nyugati pillérpár által kijelölt sávba esett volna (2-3. kép). ${ }^{54} \mathrm{Az}$ építmény, közepén a sírládával, a középkori székesegyház főhajójának nyugatabbi végében, de a főhajó hossztengelyéhez igazodva fekszik. ${ }^{55}$ Úgy is lehetne fogalmazni, hogy a sírkamra helyzete az újjáépített, ám a 12. századi épület alaprajzi elrendezését fenntartó templom testén belül - ami a sírnak a középtengelyben való kijelölését illeti - az in medio ecclesiae kritériumának pontosan megfelelt. ${ }^{56}$

A sírkamra falazata - a nyugati falát kivéve - a boltvállakig négy-négy sor kváderból áll (1, 8-13, 15-17. kép). Építésmódjára, építésének menetére jellemző, hogy az alsó zóna nagyobb méretú és jóval magasabb (a felső három soréval közel megegyező), rövidebb oldalukra állított nagyméretú kváderkövekból van kirakva (10-11, 13. kép). A sírkamra kvádereinek nagyobb része szürke tufa, azonban a déli oldalfalának nyugati végén

erre utaló nyom nem látszott), hogy a sírkamra feltárása óta eltelt közel hetven év alatt az azon egykor látható vékony habarcsréteg megsemmisült. 2004-ben a sírláda alján kisebb, szilánkosan törött vörösmárvány-darabka hevert. Mivel a márványdarabka eredeti felületekhez már nem kapcsolódott, kérdéses, hogy a kamrán belüli valamiféle szórványtöredék vagy az ásatási naplóban is említett, a kriptasír alján talált márványszilánkok egyikének maradványa lehetett-e.

54 KoZÁK 1973, 138-141. és 14-16. kép

55 Hozzátéve, hogy a székesegyház Árpád-kori nyugati része (nyugati irányban) kiterjedtebb és komplexebb elrendezésú lehetett, mint azt az eddigi kutatás gondolta. Noha a maradványok alaprajzi elrendezése bizonytalan, a Dörögdi Miklós püspök temetkezése nyomán a 14. század derekára helyezhető nyugati toronypár és az előcsarnok bizonyosan korábbi Árpád-kori maradványokra, illetve azok visszabontásával, részben felhasználásával épült. E maradványok alaprajzi elrendezése és megítélése bizonytalan, azonban datálásuk egyik fontos támpontja lehet, hogy építésük során a jelek szerint Kálmán király (1096-1116) pénzeivel keltezett temetőrészt számoltak fel. A kitüntetett helyzetú sírkamra és a székesegyház nyugati részének kapcsolata, viszonya (mind az Árpád-kort, mind a 14. századot illetően) külön tanulmányt igényelne. A kérdéshez és a nyugati részhez lásd az 18. és 48. jegyzetben idézett munkákat.

$56 \mathrm{Az}$ in medio domus, illetve az in medio templi az adott egyházakban rendszerint kitüntetett figyelemmel, "kultusszal” illetett temetkezésekkel összefüggő fogalmához a németországi emlékanyag tekintetében alapvető: OswALD 1969, 313 326.

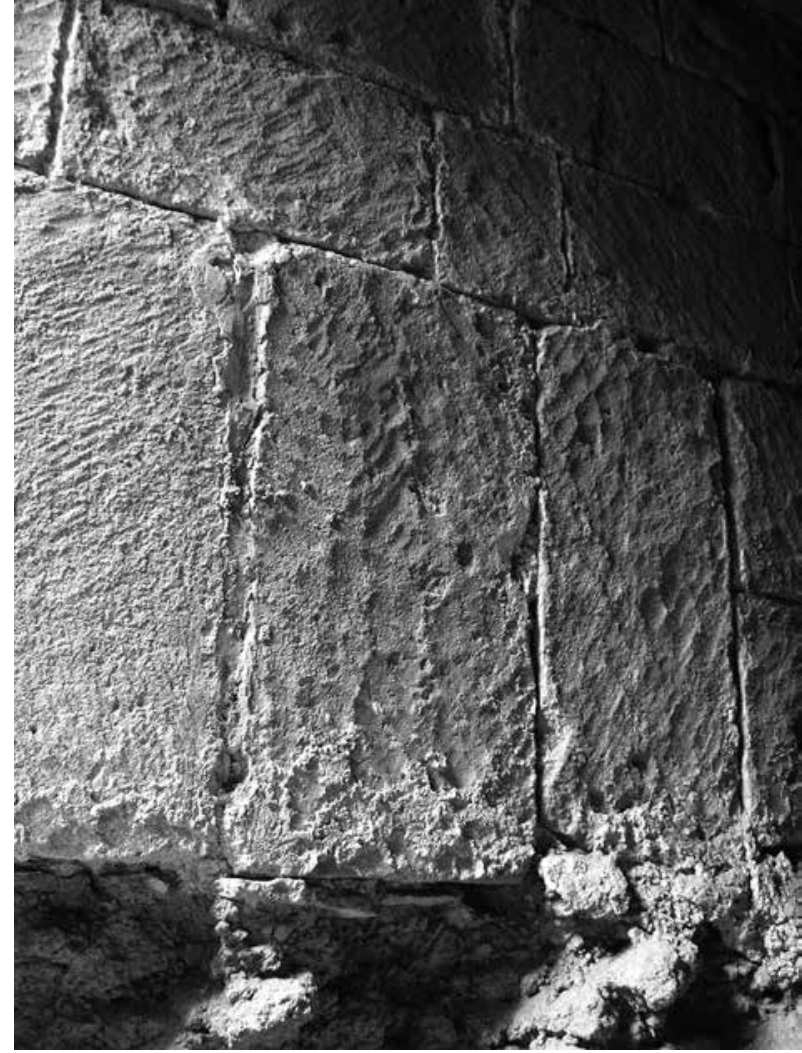

19. kép. Eger. A sírkamra északi falának bejárat felőli részlete a kváderek felületi megmunkálásával, valamint a fal alapozási habarcsába ékelt márványdarabkákkal. Jól megfigyelhető a kváderek szélein elkent, elsimított falazóhabarcs (fotó: Havasi K., 2006. augusztus)

Fig. 19. Eger. Detail of the burial chamber's northern wall towards the entrance showing the surface finish of the ashlars and the marble fragments wedged into the wall's bedding mortar. The smoothed mortar at the edge of the ashlars can be clearly seen (photo: K. Havasi, September 2004)

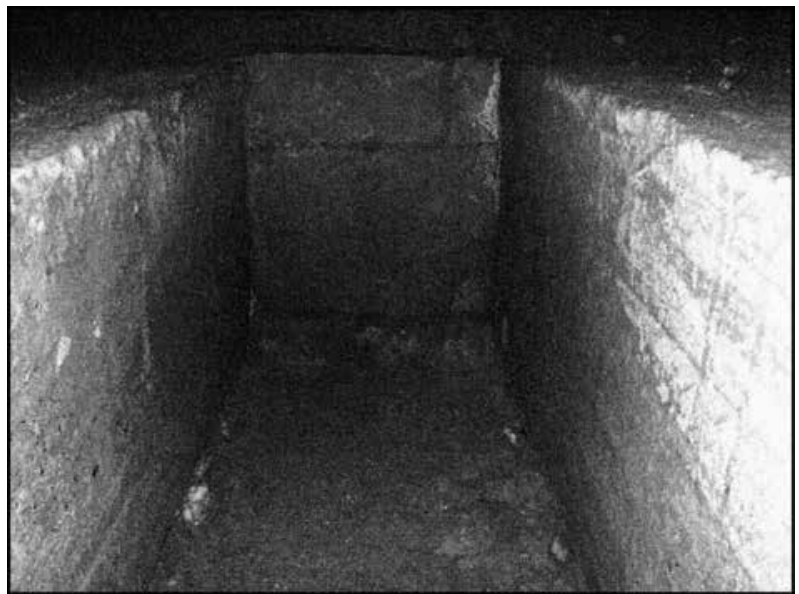

20. kép. Eger. A sírláda keleti vége, belső nézet (fotó: Havasi K., 2004. szeptember)

Fig. 20. Eger. Interior view of the chest tomb's eastern end (photo: K. Havasi, September 2004) 


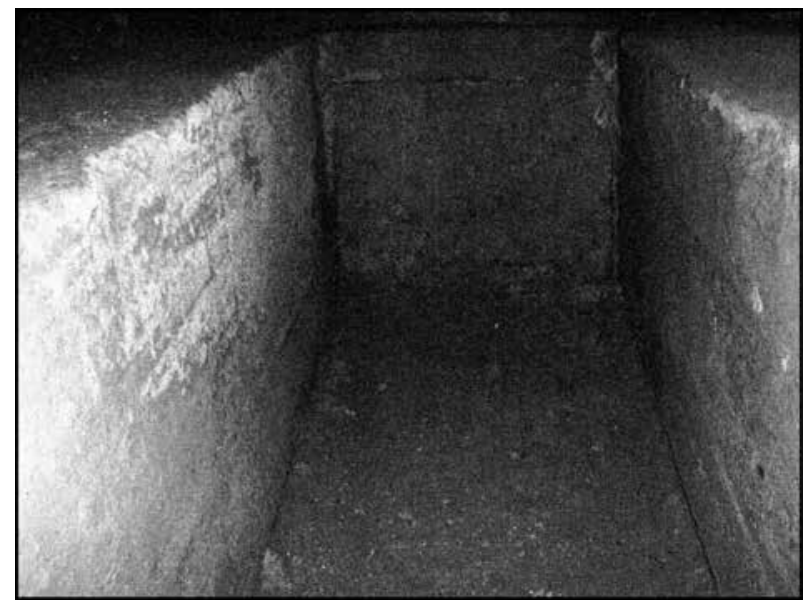

21. kép. Eger. A sírláda nyugati vége, belső nézet (fotó: Havasi K., 2004. szeptember)

Fig. 21. Eger. Interior view of the chest tomb's western end (photo: K. Havasi, September 2004)

és a nyugati falán - olyan részeken, amelyek a felvétel tanúsága szerint a feltáráskor is in situ álltak - nagyobb számban, illetve a keleti falon egy-egy kó erejéig barnássárga, illetve vöröses színú andezittufából faragott kváderek is feltúnnek. Tehát részben az a fajta polikrómia jellemezte e funerális építmény falazatát is, mint ami a székesegyház román kori részletein a főapszis és a déli mellékszentély esetében is érvényre jutott. Az alsó sort leszámítva a kváderek méretei is a szentély román kori felmenő falmaradványaival vethetók össze. A kváderek felülete hegyes vésővel, csákánnyal egyenletesen, szépen, hol nagyoltabban, hol aprólékosabban megmunkált; a kőfelületek olyanféle dekoratív textúrát mutatnak, amelyeket eleve láttatásra szántak. ${ }^{57}$ Erre utal az is, hogy a vékony fúgák közeiből kitüremkedő, finomszemcsés, meszes, fehér falazóhabarcsot a kváderek szélei mentén vakolókanállal eldolgozták, szétkenték (18-19. kép). ${ }^{58}$ A kváderfelületek megmunkálásmódja azonos, illetve rokon a székesegyház román kori felmenőin és 12-13. századi kótári töredékein láthatókkal (2628. kép). ${ }^{59}$ A sírkamra keleti falának záradékába a

57 Ehhez: Kautzsch 1944, 129-135 (Mauerwerk und Steinbearbeitung); NAGY E. 1978, 52-58; AUTENRIETH 1988, 27-70.

58 Ezáltal az abból lehullott darabkák felületük miatt vakolattöredéknek is tûnhetnének (amire amúgy szintén van példa).

59 A székesegyház in situ felmenő maradványai közül leginkább a román kori főapszis egyes kvádereinek (raktárban őrzött fragmentuma: HAVASI 2011, 245, Kat. 27), valamint az északi mellékszentélyből a főszentélybe vezető lépcsőfokok hátoldalának megmunkálásmódjával vethetők össze. A kőtári töredékek közül formai jegyeik alapján a 12. század elsó harmadára valló külső lábazati párkányok, valamint homorú élszedéssel tagolt Árpád-kori sírkövek (egykor nem látható) oldalainak megmunkálásmódja (HAVASI 2011, 237-238, 247, helyreállítás során visszaillesztett kváderkő mellett jobbra egy olyan darab látható, amely lezárásának íve alapján egykor a homlokfalnak a homlokív alatti középrészébe illeszkedő darab lehetett $(13,17,24-25$. kép). Szegmensívú oldalának záradékpontja alatt precíz körvonallal mélyen kivésett egyenlő szárú kereszt látható. Így amenynyiben e kő eredeti állapotában is e sírkamrához tartozott, ami íves lezárása miatt igen valószínú, akkor a kereszt a funerális emlékeken is alkalmazott jelkép szerepkörével bírhatott. ${ }^{60} \mathrm{~A}$ kváderen feltúnő kereszt formáját és megoldásmódját tekintve meglehetősen közel áll ahhoz a sírkőként kiegészített és a 12-13. századra datált töredéken láthatóhoz, amely egyébként Bartalos Gyula (1839-1923) egri kanonok kőfaragvány-gyújteményének ${ }^{61}$ egyik, várhegyról származó darabja volt; illetve egy másik szintén a „kőtár régi anyagából" való, kereszttel megjelölt (kváderkő/ sírkő?) töredékhez (29. kép). ${ }^{62} \mathrm{Az}$ pedig, hogy a sírkamra a feltárásakor a boltozatától eltekintve közel teljes formájában került elő, s hogy az „arzenálfal" - amely a 16. század derekától hadszertárként is szolgáló székesegyházba épített, a hosszház tengelyére meróleges falak egyike lehetett $^{63}$ - áthidalta azt, s hogy betöltésében román kori és késő gótikus töredékek egyaránt megtalálhatók voltak, leginkább arra vall, hogy az építmény eredeti formájában a késő középkorig

Kat. 12-14, 29-31), továbbá a román kori mellékapszisok késő középkori lefalazásából előkerült külső faltagoláshoz tartozó rétegkövek (HAVASI 2011, 241-243, Kat. 20) idézhetők többek között. A felület megmunkálása, a szerszámhasználat ezen jegyei tágabban és általánosan is jellemzőek a 12. századra (és részben a 13. századra is), viszont a sírkamra építéstörténeti kontextusának és korának közelítőleges lehatárolása miatt fontos kiemelni.

60 A kereszttel jelölt (sír)kövek ikonográfiai vonatkozású vizsgálatához: AzzolA 1986, 11-37.

61 Bartalos Gyula kanonok kőfaragvány-gyújteményéről bővebben: HAVASI 2015, 7-8, 32-34.

62 SzMrecsánYi 1932, 8, 22. sz.; a sírkőként kiegészített töredék a Lapidáriumban volt: KoZÁK-SEDLMAYR 1987, 15, Kat. Nr. 45. (a kőtár régi anyagából való darabként feltüntetve). A másik elveszett(?) darab fényképét lásd KozÁK 1975, 94, 17. ábra. A fényképről úgy túnik, hogy közvetlenül a kereszt bal oldala mellett húzódott a kő függóleges oldala. A kereszt alsó szára kissé hosszabb, a szárak vége pedig $\mathrm{M}$ formán kimetszett.

63 Vö. KozÁK 1973, 138-141, illetve 8, 14. kép. Kozák a sírkamra vonalába eső északnyugati mellékhajószakaszban két egymással párhuzamos, haránt irányú, újkori falalapozást is megfigyelt, a nyugatabbit az 1552-es eseményekhez, a keletebbit a török korhoz kötve. E kérdéshez lásd még az 1931. május 12-ig feltárt maradványokat összesítő, Hevessy Sándor által készített alaprajzon a hosszház keleti részén belül sárgával jelölt falalapozásokat. Forster Központ Tervtára, Lux hagyaték, ltsz. 00381. (HAVAsi 2011, 6-7. kép). 


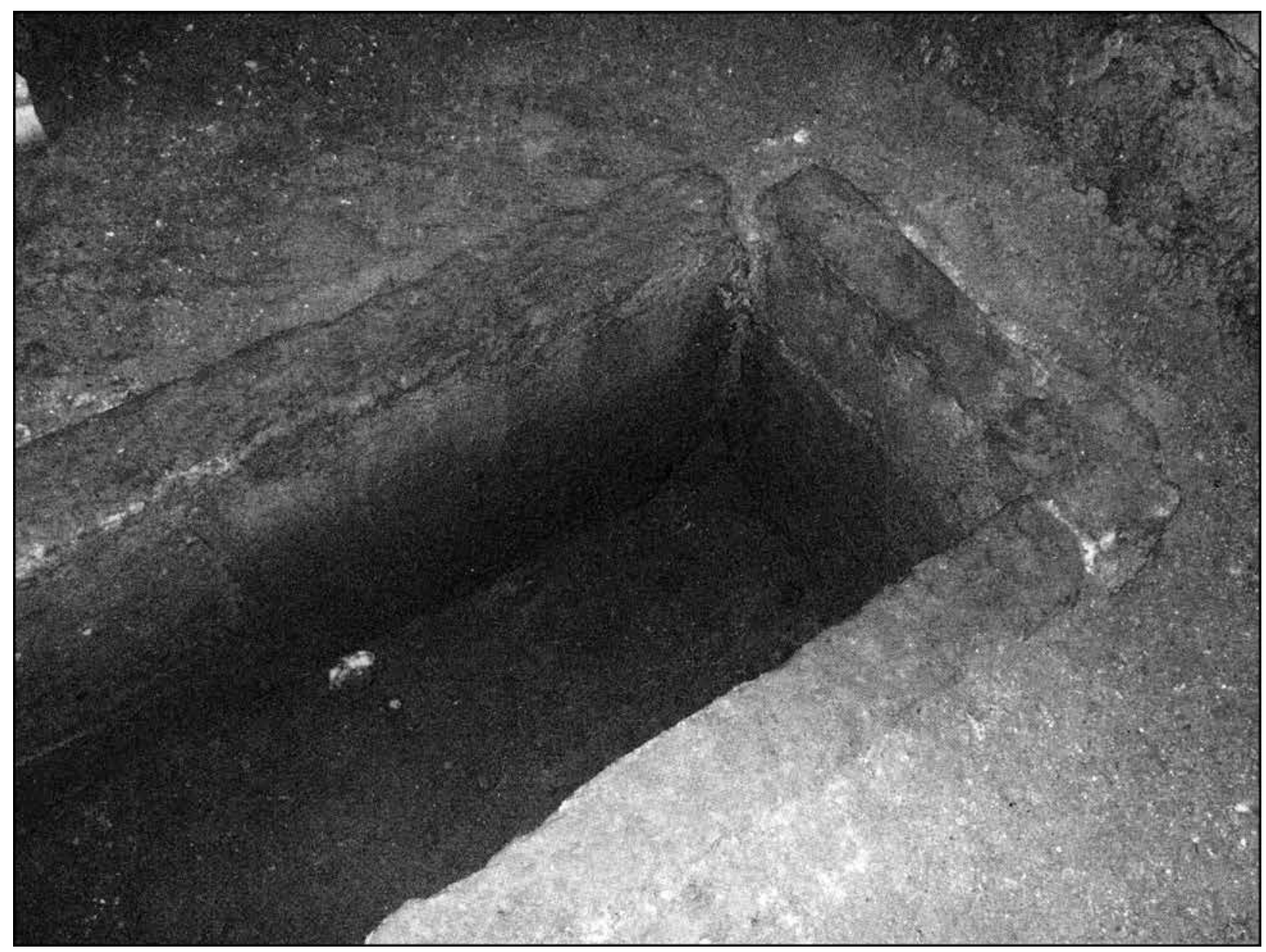

22. kép. Eger. A sírláda keleti vége felülnézetben (fotó: Havasi K., 2004. szeptember)

Fig. 22. Eger. Top view of the chest tomb's eastern end (photo: K. Havasi, September 2004)

fennállhatott, s hogy pusztulásának kezdete a székesegyházéval eshetett egybe. ${ }^{64}$

Ami a szinteket illeti, a sírkamra körítőfalainak koronája a hosszház északi oldalán feltárt román kori pillérmaradvány alapozásának tetejénél (15$20 \mathrm{~cm}$-rel) alacsonyabban helyezkedett el, a sírkamra boltozatának záradéka pedig a pillér alsó kváderköveinek (vagy lábazati zónájának - feltéve, hogy ez még nem az alapozás része!) vonala fölé nyúlt néhány centiméterrel, azonban az újjá-

64 Détshy Mihály közölte (DÉTSHY 1964, 10-11, 251. jegyzet, lásd itt a 25. jegyzetet) a várbeli templom néhány sírját feltöró Hreska Mihály salétromfőző és neje, valamint segédeik kihallgatása kapcsán 1757 áprilisában felvett jegyzőkönyvet [Verhör und Durchsuchung über das Graben in der Bischöfflichen alten Kürchen in der Festung Erlau, 1757. den 11. April], amely szempontunkból figyelemre méltó sorokat tartalmaz, hiszen a templom területén (egy félig elhordott, leomlott Zwerchmauer! mellett) lévő falazott és lépcsők révén megközelíthető kriptáról - a kutatások tanúsága szerint ilyenből csak egyetlenegy található a székesegyház területén - esik szó benne; teljes átiratát lásd HAVASI 2011, 314-323. épített hosszházban már ez is közvetlenül a padlószint alá került (3. kép). ${ }^{65}$

Az a tény, hogy a sírkamara teteje (boltozatának záradékvonala) a késő középkori járószint alá, de nagyjából féllábnyival a román kori pillérek alapozásai (ami nem biztos, hogy azonos azok egykori lábazati zónájával!) által jellemezhető szint fölé nyúlik, véleményem szerint nem feltétlenül annak a bizonyítéka, hogy a sírkamra a késő középkorban épült fel. Az eddigi régészeti megfigyelések fényében az bizonyos, hogy a 12. századi pillérekhez hasonlóan a sírkamra helyét is a bolygatatlan, darázskő altalajba vágták, s az hogy falainak koronája a fóhajó sejthető 12. századi szintjéhez közelít, inkább arra vall, hogy a sírkamra építésekor a román kori pillérek már állhattak. S ami ennek kapcsán, más kitüntetett helyzetú sírhelyek kialakítását is figyelembe véve inkább felmerül, az a - lépcsőlejáratot leszámítva a tetején - közelítőleg $3 \times 2,3$ méter nagyságú sírkamra ",felszín feletti”, azaz az Árpád-kori 65 Szintadatok: KOZÁK KÁROLY DOK. 1969, R6. nyomán. 


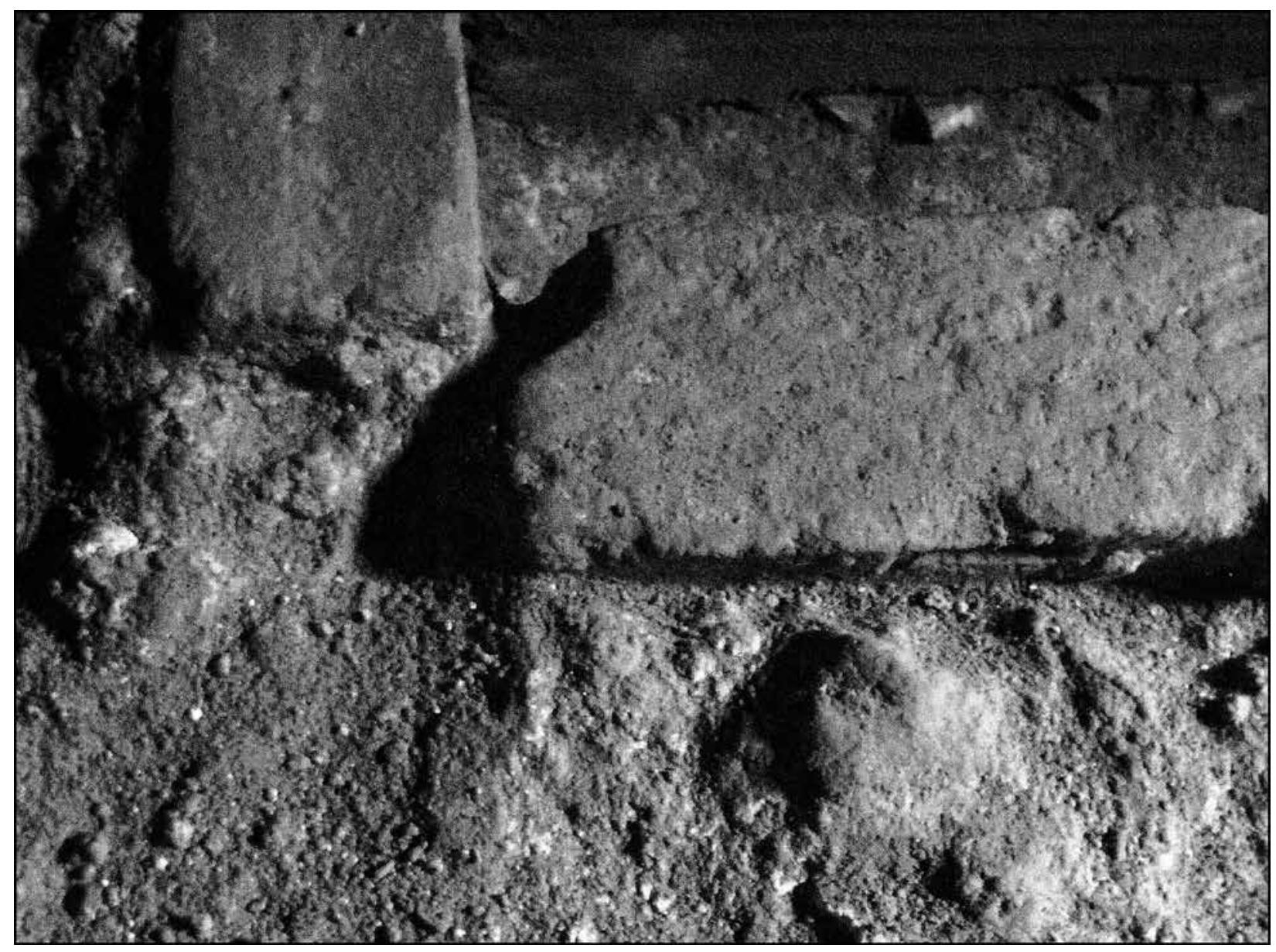

23. kép. Eger. A sírláda északi és keleti oldallapjának csatlakozása. A szemközti oldalon jól megfigyelhetők a sírláda déli oldallapjának keleti része alá ékelt márványlapocskák. (fotó: Havasi K., 2004. szeptember)

Fig. 23. Eger. Meeting point of the slabs of the chest tomb's northern and eastern side. The marble plaques wedged underneath the eastern part of the stone slab of the southern side can be clearly seen (photo: K. Havasi, September 2004)

főhajó terén belüli, járószint feletti megjelenésének és felépítményének (inkább csak hipotetikusan felvethető) kérdése. ${ }^{66}$

A feltárók a sírláda alján figyeltek meg különféle színú, fekete, fehér és vörös „aládolgozott” márványtöredékeket, melyekből márványburkolatra következtettek. A helyszíni vizsgálatok során a sírkamra felépítményével és alapozásával összefüggésben számos, másodlagosan beépített márványtöredéket lehetett megfigyelni (11-12, 14-15, 17, 19, 23. kép). Ezek egyrészt a kváderek közötti vékony fúgák finomszemcsés

66 Mindezeket az eddigi régészeti kutatások tisztázhatták volna, de az általuk feltárt és elpusztított rétegekről dokumentumok, ha egyáltalán készültek, nem ismertek. Mindez nem pótolható, de talán a sírkamrát és közvetlen környezetét érintő, az eddigieknél aprólékosabb és kifinomultabb módszerekkel dolgozó, a jelenségeket dokumentáló vizsgálatok (például a 12. századi épületmaradványok szintjei egymáshoz való viszonyának bemérése, hitelesítése és tisztázása) számos ponton tisztább képhez vezethetnének. illesztőhabarcsába ékelt, apró és rendkívül vékony fehér és halványszürkés márványlapocskák, márványszilánkok, másrészt az alsó kvádersor alatt húzódó durvább szemcsés habarcsos alapozás tetején mutatkozó nagyobb, a megmunkálás különféle fokait mutató, illetve nyers darabkák és laptöredékek. Ez utóbbiak figyelhetók meg a sírláda oldallapjai alatt is, közvetlenül az ágyazóhabarcs és a kólapok között. A sírkamra belső, északnyugati részén egyrészt a bejárati küszöb foka alatt fennmaradt alapozásmaradvány felső felületén, részint a küszöbkő eredeti fektetőhabarcsába kötve egészen vékony $(\sim 1 \mathrm{~cm})$ szürkés és kékesfekete, mindkét oldalukon simára munkált márványlapocskák láthatók. Ez a kótári anyagból is ismert, „fekete márványnak látszó” kóanyag könnyen - s szemmel láthatóan gyakran egybefüggő sík felületek mentén - hasítható, helyi eredetú díszítőkő. Felülete éles fényưvé csiszolható, azonban tagozatfaragásra, plasztikus formálásra tömörsége és hasadási tulajdonságai 


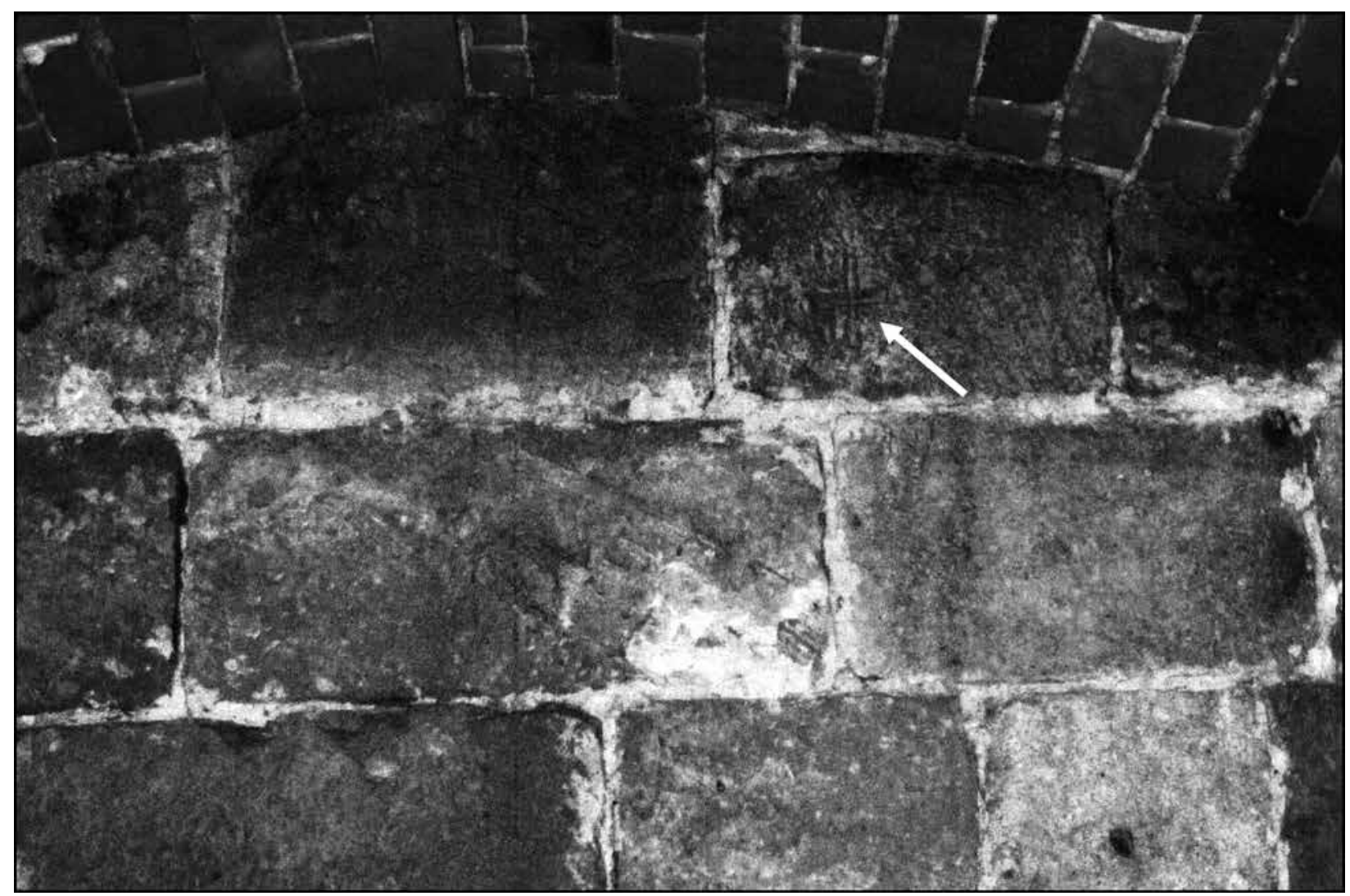

24. kép. Eger. A sírkamra keleti falának bolthomloka a záradékrésszel, a középtengelytől délre visszaépített, kereszttel jelölt kváderkővel (fotó: Havasi K., 2004. szeptember)

Fig. 24. Eger. Vaulting of the burial chamber's eastern wall with the crown and the ashlar with the carved cross south of the central axis (photo: K. Havasi, September 2004)

miatt - ellentétben a helyi fehéres színú márványnyal és annak szürke változatával - úgy túnik, teljességgel alkalmatlan volt. A ránk maradt emlékek tanúsága szerint e kőfajta nagyarányú alkalmazására a középkori székesegyház építéstörténetében - szemben a szürkésfehér és a vöröses változatokkal - csak egyetlen alkalommal került sor. ${ }^{67}$ Akkor kizárólag díszpadló különféle formájú szemei, elemei, mégpedig a legprecízebb szabásúak készültek belőle. Ez felvetheti azt is, hogy e helybeli, feketés színú kőanyag díszítőkőként való felfedezésére épp a padlóval összefüggésben (vajon a padlókészítók érdeme?) kerülhetett sor. E reprezentatív padlóburkolat kialakítása pedig a márványnak a kisarchitektúrával való összefüggése, továbbá stiláris megfontolások alapján a 12. század végére, illetve a kora 13 . szá-

67 Ezt azért is érdemes hangsúlyozni, mert a fehér és a szürkésfehér színú márvány, valamint a vörös márvány (nem feltétlenül helyi, hanem gerecsei változatának) alkalmazása ismert a késő középkori egri anyagban is. Lásd reneszánsz fehérmárvány dombormú töredékei (HAVASI 2006), illetve vörösmárvány sírkövek, síremlékek (többek között): LővEI 2010, 435-436. zadra tehető. ${ }^{68}$ A sírkamrában, a fúgákban, az illesztékekben és az alapozások tetején megfigyelhető darabok minden bizonnyal kiékelésre szolgáltak. Tehát a maradványok jelen állapotában a sírkamrán belül bizonyosan díszburkolatra utaló nyom nem figyelhető meg. Ugyanakkor nem kerülhetó meg és nem feltétlenül alaptalan az 1937es kutatók erre vonatkozó kérdésfeltevése. Mindezt azonban a pusztulás és a pusztítások miatt már nehezen lehet megítélni. A sírkamra padlószintjének feltörése és durva elbontása - melynek célja egykor nyílván a sír megtalálása, kifosztása lehetett, s melynek következtében a sírláda teteje és a sírládában lévő dolgok a sírláda aljának jelenségeivel együtt eltúntek, elpusztultak -, a küszöbkő külső oldalával egybefaragott és kimélyített, nagyolt fellépő felület $(7,9,10$. kép) kiképzése csupa olyan jelenség, melyek részben hasonló irányban való gondolkodásra késztetnek.

\footnotetext{
68 A kisarchitektúra töredékeiről és a székesegyház 12-13. század fordulójára helyezhető átépítésnek faragottkő-emlékanyagáról: HAVASI 2003, 113-186; 2011, 248-307.
} 


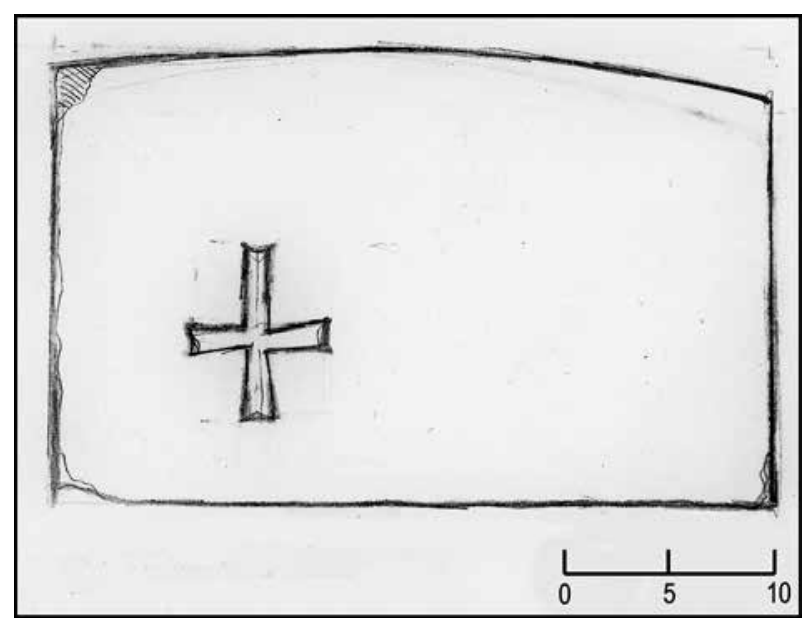

25. kép. Eger. A sírkamra keleti falának záradékába, a középtengelytől délre visszaépített, kereszttel jelölt kváderkő felmérési rajza (rajz: Havasi K., 2004. szeptember)

Fig. 25. Eger. Survey drawing of the ashlar with the carved cross south of the central axis in the burial chamber's eastern wall (drawing: K. Havasi, September 2004)

A sírkamra falazástechnikája, a kváderfelületek és a sírláda ${ }^{69}$ megmunkálásmódja, a falazat polikrómiája, illetve a kereszttel jelölt kó a korábbi feltételezésekkel ellentétben mind amellett vallanak, hogy a sírkamrát tágabban a 12. század folyamán, illetve a 13. század első felében építhették a székesegyház román kori épületének szerves részeként. Azonban a sírkamra építési korául felvethető ezen bő évszázadnyi időszakot az építmény belső alapozásának felületén és a kváderek illesztékei között fennmaradt „márványlapocskák” leszúkíteni látszanak, mégpedig a székesegyházbelső 12-13. század fordulójára helyezhető kicsinosításának, márványarchitektúrával és díszpadlóval való felékesítésének korára. Úgy túnhet, mintha a sírkamra építése kapcsán ennek törmelékeit, a megmunkálás feleslegessé vált darabkáit, „múhelyhulladékait" hasznosították volna.

\section{Történeti összefüggések}

Akár a 12. század folyamát, akár 1200 táját tekintjük, a források és a történeti adatok tükrében meglehetősen leszúkül azon személyek köre, akikkel kapcsolatosan ezen reprezentatív sírépítménybe való temetkezés lehetősége felmerülhet.

69 Közvetett észrevétel, de a hosszanti oldallapok fúrészelt felületei kapcsán talán nem érdektelen megjegyezni, hogy a kisebb-nagyobb felületen fúrészeléssel képzett hasonló kőlapok alkalmazása szintén a kisarchitektúra márványtöredékei kapcsán túnik fel, burkolólapok, padlóelemek és (talán) egy vakfülkehát kapcsán.
A 12. század első felének névról ismert egri püspökei közül Procopius (1102), Wolfer (1111-1113) és Beztrius (1135) az őket említő okmányokban is e cím viselóiként szerepelnek, távozásukról más egyházmegye élére nincs tudomás. ${ }^{70} \mathrm{~A}$ korszak két meghatározó püspökének, az építtetőként, alapítóként is számon tartott Martiriusnak (1142/1150-1157/1158) és Lukácsnak (1157/11581181) az esztergomi érseki székben tetőződő pályafutása ismeretes. A forrásokban nevének említésével együtt fennmaradt következő utóduk, Chemma pedig egri püspöksége után 1166-1169 között kalocsai érsekké lett. ${ }^{71}$ A századforduló mindkét püspöke, Péter (1181-1197/1198) és Katapán (1198-1217) is az egri egyházmegye fópapjaként hunyt el. ${ }^{72}$ Mindazonáltal a korabeli nyugati emlékanyagban sem ismerek példát arra, hogy a püspöki, illetve érseki hamvakat órző sírláda - ha még oly kitüntetett részen helyezték is nyugalomra, mint az egyház közepe - különálló, föld alatti építészeti foglalattal együtt létesült volna. ${ }^{73}$ Szentek, szentként tisztelt személyek, alapítók és királyok temetkezése kapcsán annál inkább felmerül ez a forma. ${ }^{74}$ A magyarországi

70 Wolferre vonatkozóan lásd SzENTPÉTERY 1923, I, 16, no. 43. (1111-ből); Beztriusra vonatkozóan: SzENTPÉTERY 1923. I, 21, no. 60. (1135-ből); Procopiushoz és a többiekhez: Zsoldos 2011, 87. Megjegyzendő, hogy 1138-ban a csanádi püspökök között feltûnt egy Beszteréd nevú: Zsoldos 2011, 86.

71 SZENTPÉTERY 1923. I, 37, no. 112; KATONA 2001, 103-104; ZsOLDOS 2011, 83-84.

72 SCHMITTH 1768. I, 102-103; SUGÁr 1984, 56-61.

73 Oswald 1969, 319-321, Fig. 3-4; Friedrich Oswald példái közül: az 1180-as évek elején (1183) „felemelt” Anno kölni érseknek (1056-1075) a siegburgi apátsági templom fóhajojában a Szent Kereszt-oltár előtt (s a padlószint alatt) elhelyezett sírládája. (A vizsgálat másik, a hazai emlékanyag viszonylatában legfeljebb csak kérdésfeltevésként megfogalmazható szálát az jelenthetné, hogy e kiemelt helyzetú - uralkodót, főpapot, gyakran utóbb szentként is tisztelt személyeket rejtó - temetkezéseket milyen "padlószint feletti” monumentumok jelölték/illették.) Az egri sírkamra feltételezett korából itthonról talán egy hiteles fópapi sír idézhető. Az első kalocsai székesegyház apszisa előtt feltárt (a hossztengellyel párhuzamosan, de attól valamennyivel északabbra kijelölt), érseki hamvakat őrző sírláda. FoERK 1915, 43-47. A mellékletek alapján hosszú ideig 11. századi érsek (Ashcerik) temetkezésének tartották. Vö. NAGY Á. 1968, 112-123. A leleteket (pásztorbotvég, patena, kehely, gyúrú; jelenleg kiállítva: Kalocsa, Főegyházmegyei Kincstár) a múvészettörténeti kutatás a Győr nembeli Saul érsekkel (1192/1193-1202) hozta összefüggésbe. GEREVICH T. 1938, 243-244, CCLVI/1-2, 4. kép, illetve CCLXI/7; MAROSI-WeHLi 1997, 31, 81-83. kép. A vörösmárvány lapokból összeállított sírláda közvetlenül is III. Béla és Antiochiai Anna - azonosítását tekintve újabban Tóth Endre által vitatott - székesfehérvári sírjával vethető össze. Lásd KRALOVÁNSZKY 1989, 168-169, és 14/a-b kép, valamint Biczó 1999, 16-23, 1-2. kép; То́тн E. 2006. Újabban a kalocsai sír kora szintén és ismét vitatottá vált: BUZÁs 2014.

74 Ezekhez többek között: Komm 1990, 89-124; CHEvalierMAQUET 2004. 


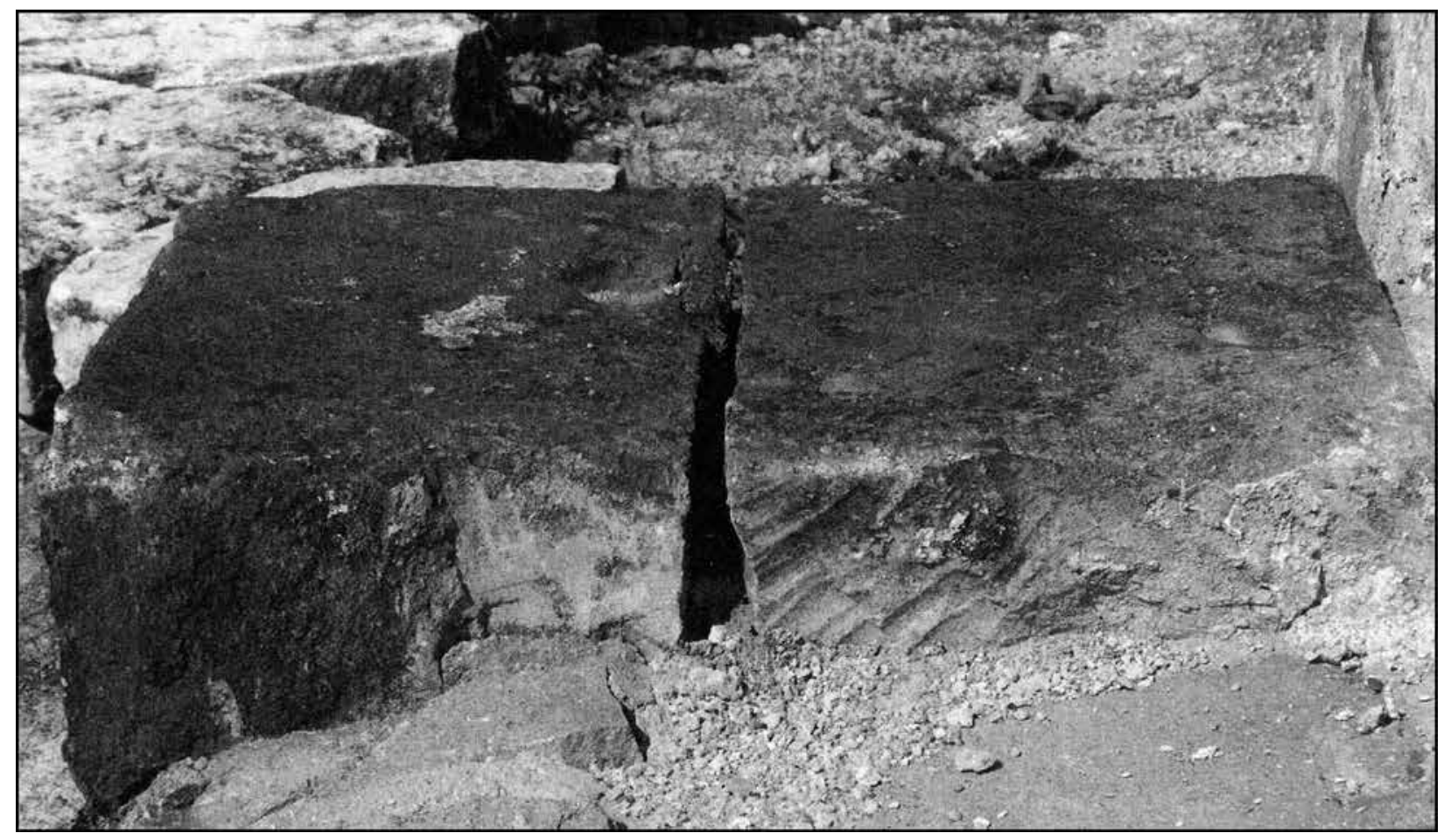

26. kép. Eger. A székesegyház északi mellékszentélyéből a főszentélybe vezető 12. századi lépcsőrészlet felső fokának hátoldali megmukálása (fotó: Havasi K., 2007.)

Fig. 26. Eger. Surface treatment of the back side of the upper step of the 12th-century flight of steps leading from the cathedral's northern side-sanctuary to the main sanctuary (photo: K. Havasi, 2007)

emlékanyagban ennek fennálló - ám rendeltetésükre nézve vitatott - Árpád-kori emlékei Feldebrőhöz, a pécsi székesegyházhoz és a somogyvári bencés apátság templomához kötődnek.

Feldebrőn a Szent Kereszt-oltárral és altemplommal összefüggésben, annak apszisával szemközti nyugati bővítményként látható az a sírkamra oltárral és sírládával, valamint keleti bolthomlokán a halotti liturgiára, mennybevételre is utaló freskórészlettel, amely építészeti kialakítását, formáját, szegmensíves dongaboltozatát tekintve az egri emlék földrajzilag közeli párhuzamaként, előképeként is idézhetó lenne. ${ }^{75} \mathrm{~A}$ feldebrői altemplom egyidejú függelékeként megépült, kváderfalú sírládát befogadó sírkamrájának Aba Sámuel (1041-1044) abasári monostorába történő „translatiója” előtti eltemetésének helyével való összefüggése, illetve az összefüggés kérdése a szakirodalomban rendre felmerült. ${ }^{76} \mathrm{~A}$ pécsi székesegyház esetében a templom keleti részének teljes szélességére kiterjedő altemplommal össze-

75 Forster Központ Fotótár, neg. 1tsz. 113480-113481.

76 SRH I, 332; KOVÁCS B. 1966, 76-79; 1968, 124-125; GYÖRFFY 1982, 67; То́тн M. 1981, 31-35; KOVALOVSZKi 1981, 40-41; 1987, 4-7; Tóth M. 1987, 103, 18. kép; Marosi-Wehli 1997, 19, 40. kép; Marosi 2000b, 615-616, illetve 400. kép. függésben annak nyugati részén kialakított $\mathrm{s}$ a Szent Kereszt-oltár alá nyúló sírkamra létezését, valamint a sírkamrának - a székesegyház építtetésében is közremúködő - Péter király (10381041/1044-1046) nyughelyével való azonosítás lehetőségét Tóth Melinda vetette fel. Ugyanő vont párhuzamot a pécsi altemplommal összefüggó elrendezés és a feldebrői plébániatemplomban feltárt maradványok között. ${ }^{77}$

77 Tо́тн M. 1987, 102-105; 1994, 124. Pécshez és Feldebrőhöz újabban: SZAKÁcs 2010, 694-696, 699-704. A fenti elókeló helyzetú temetkezések mellé helyezhető (a Szent Keresztoltár kapcsán) egy feltehetően szintén korai, de csak későbbi okleveles forrásban fennmaradt, több szempontból is figyelemre méltó passzus, amely a kérdéses kolostoregyházat jelentékeny adományokkal (liturgikus felszerelési tárgyakkal) támogató magas rangú személy (translatio-t követő) Szent Kereszt-oltár elé való eltemetéséról emlékezik meg. („Dux quoque Damazlaus exceptis prescriptis idem decoravit atque ditavit monasterium: scilicet tabula argentea ante altare Sancti Benedicti et altari argenteo ad viam et ecclesia in honore Omnium Sanctorum dedicata, in qua persoluto mortis debito sub altare corpus eius honestissime est sepultum. Postea vero transactis multorum temporum curriculis, dum corpus eius effoderetur transferendum in monasteium Beati Benedicti, mirabile signum sub oculis omnium ibi circumstancium apparauit, ut oleum purissimum tante quantitatis in sepulchro cum suis ossibus inveniretur, quod vix quinque vel sex sextarii potuissent apere, quod cum 


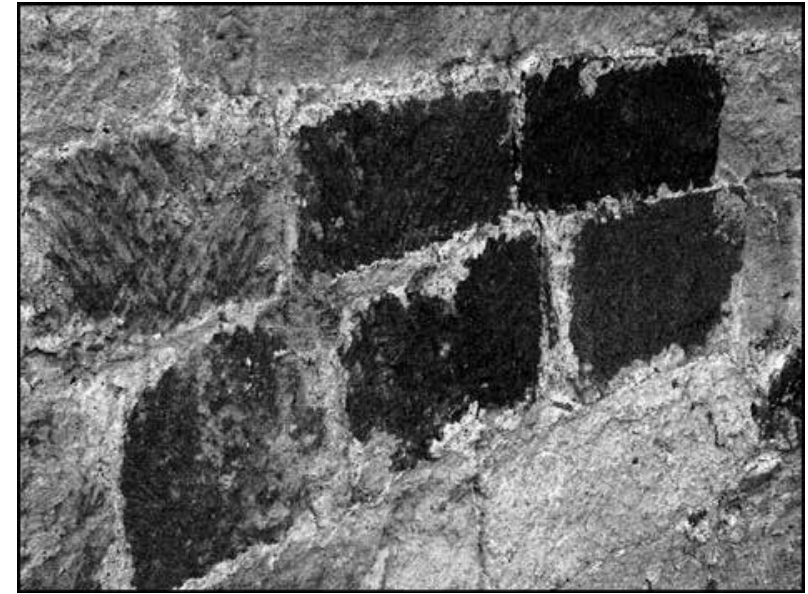

27. kép. Eger. Részlet a székesegyház román kori főapszisának belső kváderburkolatáról (a felső sorban balról a második tufakváderen emberfejet ábrázoló középkori bekarcolás látható), 12. század (fotó: Havasi K., 2007.)

Fig. 27. Eger. Detail of the cathedral's ashlar-clad Romanesque main apse, with a medieval incised depiction of a human head on the second ashlar from the left in the upper course, 12th century (photo: K. Havasi, 2007)

Somogyváron az apátsági templom hosszházának nyugati végében, a főhajó középtengelyében, a nyugatról számított második pillérpár vonalában feltárt és a késő gótikus újjáépítés során is befoglalt kisebb méretú sírkamra, mely leginkább ereklyesír lehetett, a templomon belüli elhelyezését, helyének a szentélytől és kórustól "távolabbi" nyugati kijelölését tekintve figyelemre méltó Eger szempontjából. ${ }^{78}$ Azonban az egrihez talán leginkább hasonló, a templom testén belül, annak középtengelyében, igen előkelő helyen - in medio domus - a padlószint alatt létesített, reprezentatív kialakítású sírkamrára az Árpád-kori fótemplomok emlékanyagát tekintve két helyről, a 11. század két szentté avatott királyának templomából hozható párhuzam, a

eisdem ossibus inde translatum est et ante altare Sancte Crucis cum honore summotraditum est sepulture ...") Teljes szövege közzétéve: DHA I, 77; lásd még: MEző 2003, 351; HAVASI 2004, 50-51 (126. jegyzet); BODÓ 2010, 350-351.

78 Itt a királytemetkezés lehetősége több szempontból is vitatott, vitatható. A keskeny, mély „akna” már csak méretei folytán sem elhunyt személy számára, annak nyughelyeként épülhetett, sokkal inkább ereklyék befogadásra szolgáló sírépítményről lehetett szó. E tekintetben az alapító László király 1192-es szentté avatásával, a király ereklyéivel való összefüggés lehetősége éppúgy számba vehető, mint a tituláris szent, Szent Egyed ereklyéinek tisztelete. A temetkezésre vonatkozó történeti forrásokról és a somogyvári sírhelyről: MÁTYÁs rec. 1900, 738-740; DERCSÉNYI 1934, 11-12; BAKAY 1975, 205; TóTH M. 1992, 226; PAPP 2001a, 303; 2001b, 352; То́тн S. 2001, 238-239 és 262 (61. jegyzet). A somogyvári sírról legutóbb: BAKAY 2011, 181-186. Szent László temetési helyéhez a források tükrében legújabban: SOLYMOSI 2012, 151-171. székesfehérvári Szúz Mária-prépostságból és a szintén Mária tiszteletére alapított váradi székesegyházból. A középkori váradi székesegyház középtengelyében azonban a 19. századi ásatások rajzairól ismert sírkamrákkal kapcsolatosan csak a korabeli kutatásban s csak elméleti síkon merülhetett fel az, ${ }^{79}$ ami a székesfehérvári egyház „közepén” Kralovánszky Alán által négy évtizede feltárt, Bonfini szavaival élve "földalatti bolthajtás" esetében a források híradásai nyomán is elmondható, tudniillik hogy abban Magyarország (utóbb szentté avatott és oltárra emelt) királyának (szarkofágba zárt) hamvai nyugodhattak. ${ }^{80}$

79 HenszlmanN 1884, 168-174. I. tábla (alaprajz); Henszlmann az első székesegyház középtengelyében lévő két sírkamra közül a keletebbit Szent László (1077-1095) sírjának, a tóle nyugatabbra lévőt Luxemburgi Zsigmond sírjának (13871437) tartotta, akiról azonban az elmúlt évtizedekben - a 18. század derekán előkerült sírleletei azonosításával (KovÁcs É. 1982, 89-90) - feltételezhetővé vált, hogy a „második” székesegyház szentélyében helyezték nyugalomra. KERNY 2006, 475-479; köszönöm Kerny Teréziának, hogy a témával kapcsolatos bővebb tanulmánynak kéziratát olvashattam Kerny Terézia: Megoldott és megoldatlan problémák Luxemburgi Zsigmond király temetésére és váradi sírjára vonatkozóan (Adalékok a hazai régészet kezdeteihez. Történeti adatok és kutatástörténeti vázlat). Az 1192-ben szentté avatott László király sírjának, „oszlopokkal ékes márvány síremlékének" a székesegyházon belüli lokalizálására vonatkozó forrásokkal nem rendelkezünk. Lásd ehhez: KERNY 1989, 159-167, alaprajz: 3-6. kép. A középkori nagyváradi székesegyház középtengelyében épült két nagyobb méretư sírkamráról csak az 1883-as ásatás során készült alaprajzi felvételek és metszetek ismertek, pontosabb (és középkori) keltezésükhöz egyéb támpontok jelenleg nem állnak rendelkezésre.

80 BONFINI 1936, 81 (Decas II. Liber II.); A Szent István-sírral kapcsolatban idézi: MAROsI 2000a, 626; lásd még: MAROsI 2000c, 349-363. A székesfehérvári bazilika főhajójának középtengelyében az egykori - keletről számított - 4. és 5. pillérpár vonalában, a padlószint alatt feltárt, kváderfalú, Kralovánszky Alán értelmezése szerint északnyugat felől lépcsővel megközelíthető (sír)kamramaradvány a szentté avatott István királylyal, kiépítése az 1083-as eseményekkel hozható összefüggésbe. Biczó Piroska legújabb kutatásai nyomán a sírkamrával összefüggésben a lépcső nem igazolható (BICzó 2015). Az építmény elnevezései a szakirodalomban: kultuszhely, ereklyesír. SRH II, 431-432, 436-437; KRALOVÁNSZKY 1988, 166169; KRALOVÁNSZKY 1989, 156-168; BicZÓ-TÓTH M. 2000, 623; Biczó 2001, 286-287; MAROsi 2000a, 625-626; TóTH E. 2006, 144. Szent István székesfehérvári sírkamráját valószínúleg az eredeti királysír helyén, a kórus nyugati homlokfalától egy szakasszal nyugatabbra építették ki, ereklyesírjának felépítménye és oltára a templom e részén koncentrálódó kisépítészeti alkotások együttesével bizonyára a térszervezésben is lényeges szerepet játszott. A régészeti kutatások során alapozásaikban megragadható belső építmények: a főhajó harmadik pillérpárjának keleti vonaláig benyúló kórus(rekesztő)fal és a 3. és 4 . déli pillér között feltárt, korábban ambóként, utóbb ismeretlen rendeltetésú kisépítészeti alkotásként említett építmény. Vö. Biczó-TóTH, M. 2000, 622, 404. kép.) A Szent István-sír tekintetében, különösen a sírépítmény középkori elrendezésének, fennállásának, periódusainak és 


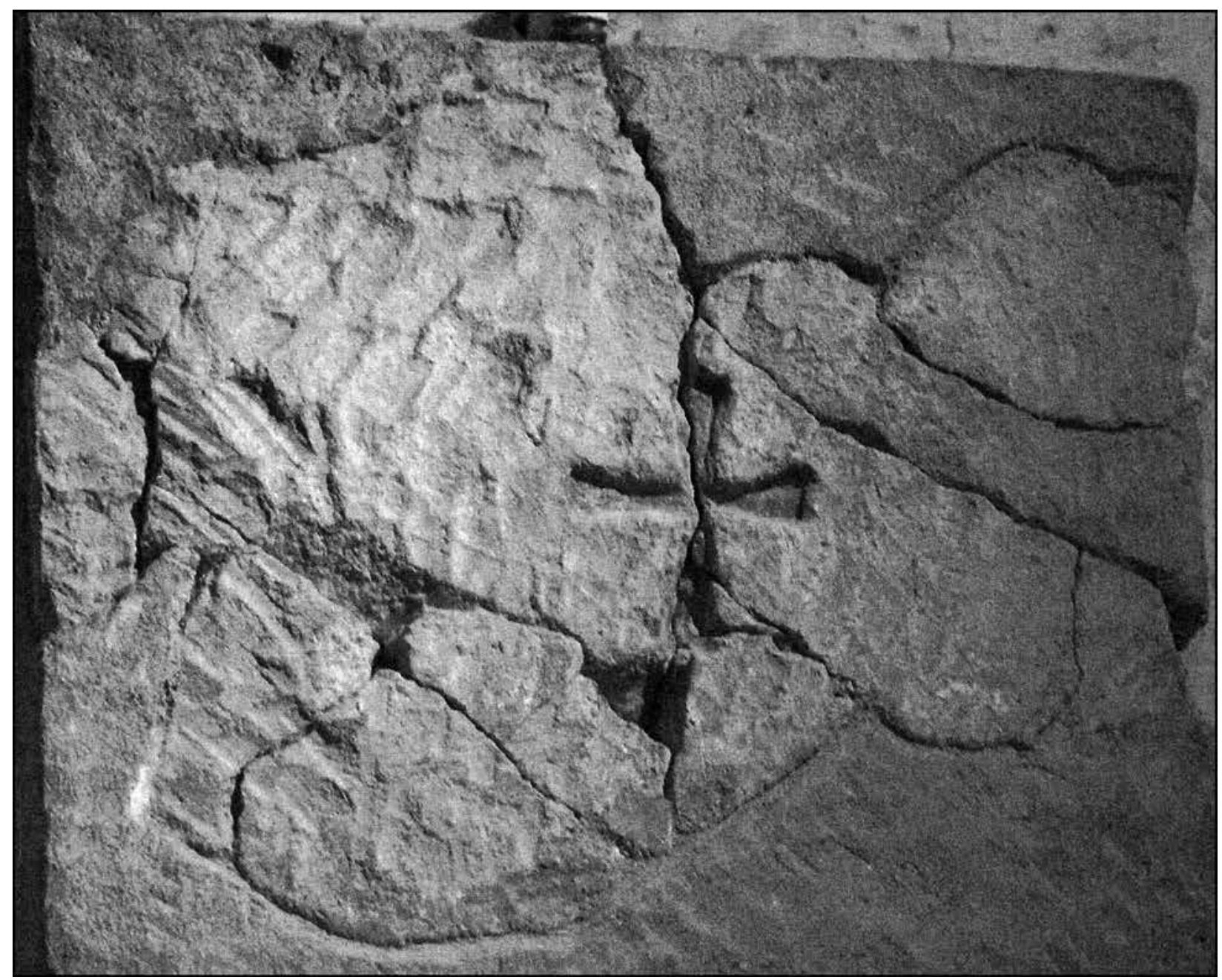

28. kép. Eger. Részlet a székesegyház környezetében előkerült Árpád-kori (12-13. századi) sírkő oldalának felületmegmunkálásáról (fotó: Havasi K., 2005.)

Fig. 28. Eger. Detail of an Árpádian Age (12th-13th century) gravestone and the surface treatment of its side found in the area of the cathedral (photo: K. Havasi, 2005)

Miként az a magyarországi érsekeket és püspököket illető uralkodói tizedról számot adó 1184-es összeírásból is kitûnik, a vizsgált időszakban az egri püspök az esztergomi érsek után a második legnagyobb jövedelem birtokosa volt. ${ }^{81} \mathrm{Ez}$ az egyházmegye területi kiterjedésével, a Felvidéktól a Nyírségig terjedő hatalmas birtokállományával is magyarázható, azonban 12. századi (és későbbi) püspökeinek pályafutása is jelzi ezt a rangot. A század közepének, második felének két meghatározó egyházfóje, a múvészettörténetbe a hozzá fúzhető felszentelési adatok

a hozzá kapcsolódó (dísz)padlóknak a régészeti kontextusát illetően Biczó Piroska eddigi ásatási dokumentumokat részletesen feldolgozó legutóbbi tanulmánya nyomán jóval árnyaltabb a kép: Biczó 2015, 299-323.

81 KNAUZ 1865, 552-554; SUgÁR 1984, 91-92; ifj. BARTA-BARTA 1993, 415-419. nyomán „építtetőként” is bevonuló Martirius $(† 1157 / 1158)^{82}$ és a Párizsban kánonjogot tanult Lukács $(† 1181)^{83}$ is Egerból került az esztergomi érseki székbe. Az 1181-1197 között egri érsekként

82 Martirius 1142-1150 között volt egri püspök, 1150 után haláláig pedig esztergomi érsek. SCHMITTH 1768, I, 67-74; MEZEY 1971, 111-112; SugÁR 1984, 43-45; Zsoldos 2011, 80, 88. Az egri egyházmegyében álló széplaki bencés kolostor 1143-as felszentelése (HERVAY 2001, 516-517) és az 1156-os esztergomi adat nyomán az egri székesegyház 12. századi építkezéseivel kapcsolatban személye a kutatásban többször felmerült. IPOLYI 1865, 119, 131; CSEMEGI 1935, 217-223. Sajnos Széplakról az alaprajzi elrendezésen túl nem sokat tudni. Lásd TóтH S. 2001, 244 és 27. kép.

83 1156-ban Párizsból, Girardus de Puella magiszter iskolájából való hazatérése után lett egri püspök, 1158-tól esztergomi érsek. GYÖRfFY 1970, 153-154; SUGÁR 1984，47-51; FÜGEDI 1986, 38; МАКК 2007, 126-127. 


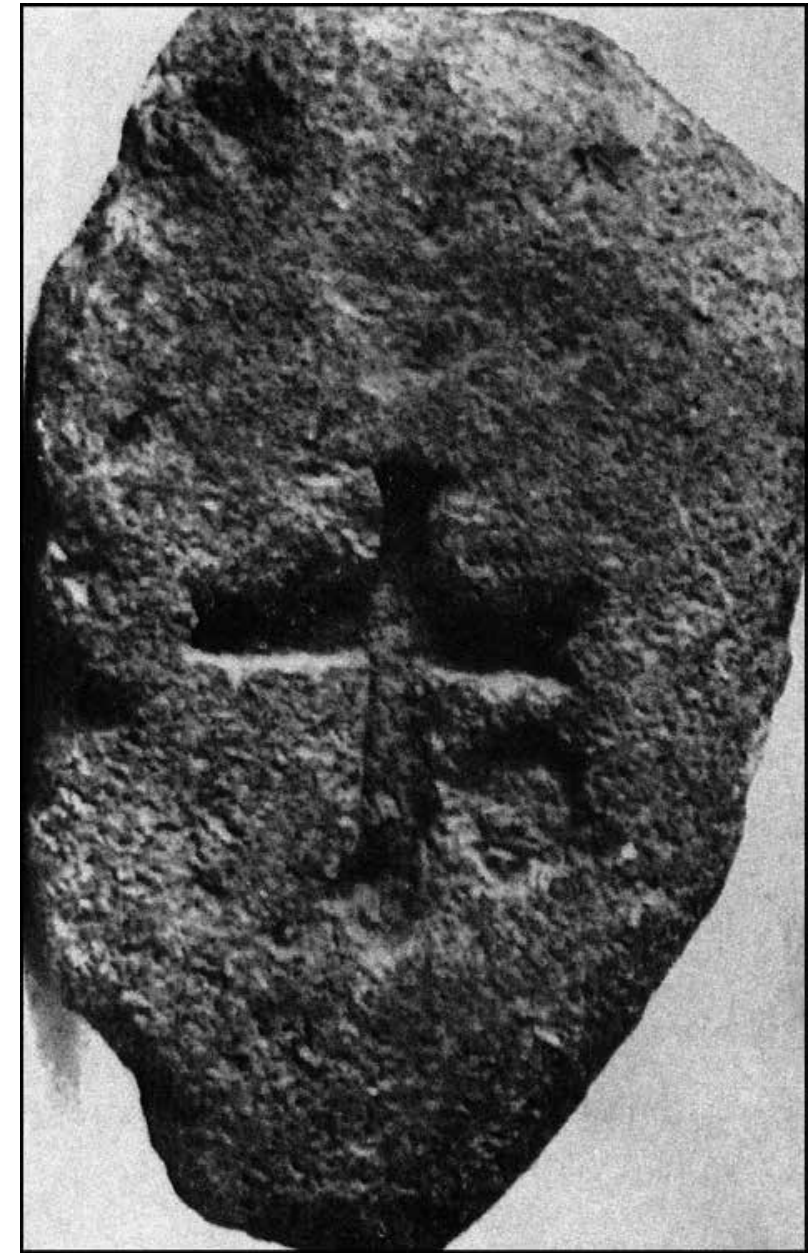

29. kép. Eger. Székesegyház. Egykor a Lapidariumban kiállított, kereszttel díszített Árpád-kori sírkő részlete (KozÁKSEDLMAYR 1987, Kat. 46.)

Fig. 29. Eger. Cathedral. Detail of an Árpádian Age gravestone decorated with a cross, previously exhibited in the Lapidary (after KOZÁK-SEDLMAYr 1987, Cat. no. 46)

múködő Péterről keveset tudunk. ${ }^{84}$ A századfordulón, 1198-1217 között Katapán viselte az egri püspöki tisztet, akinek pályafutása a fennmaradt adatokból valamennyire körvonalazható. Székesfehérvári prépostként előbb III. Béla, majd Imre király udvarában 1190-1192 között alkancellárként, utóbb 1198-ig kancellárként múködött. ${ }^{85}$ Nem tudni, hogy 1200 táján az Imre és András

84 Kivéve, hogy 1178-ban már egri prépost lehetett. SUGÁR 1984 56-58. Ha hihető az a 13. századi oklevelekben rögzített hagyomány, mely szerint az egri püspök a király fiainak „nevelésében” is részt vállal, Imre és András esetében leginkább rá gondolhatnánk.

85 SCHMiTTH 1768, I, 103-118; KUBINYI 1975, 115-117; SUGÁR 1984, 59-61; GYÖRFFY 1987, 85; ZsoldOS 2011, 88. Az 1198-ból fennmaradt oklevelek közül Katapán királyi kancellárként egyet, választott egri püspökként már többet jegyez: SzENTPÉTERY 1923, I, 53-54, no. 172-177. között dúló, főpapokat is megosztó testvérviszályban miképp foglalt állást. Jóbbal (†1203/1204), Jánossal (†1222), Calanusszal (†1218/19) és Boleszlóval (1193-1212) ellentétben Katapán noha ezekben az években mind a király, mind a püspöki kar élénk levelezésben állott III. Incével - inkább „eltúnni látszik” a forrásokból. ${ }^{86}$ Mindenesetre székesegyházának uralkodói temetkezési helyként való kiválasztása inkább Imre-párti fópapot sejtet, kérdés, hogy a király halála után ez miképp alakult. Az egri egyház előkelő helyzete mellett többek között Katapán püspöknek a 12. század végén, a 13. század elején bizonyosan szoros udvari kapcsolatai is közrejátszhattak abban, hogy a részben már Esztergomot is elhagyó Imre - a Fehérvárra temetkező uralkodók sorát ismét megszakítva - nyughelyéül az egri székesegyházat választotta. ${ }^{87}$ E választás emlékét a főhajó kváderfalazatú, boltozott sírkamrája képviselheti. Az ezen boltozott foglalattal együtt létesült egri sírépítményben szentek ereklyéit, illetve különösen tisztelt személyeket: uralkodókat, építtetőket és alapítókat illető reprezentatív és a memoria fenntartására kiváltképp alkalmas építészeti forma valósulhatott meg. Olyan építészeti forma, mely valamiképp a temetkezés helyének megelőlegezett, tudatos kiválasztásáról tanúskodhat. Mindez a belső átépítés, a márványarchitektúrával való felékesítés és a sírkamra egymáshoz való viszonyán túl a püspök mellett a király építtetői szerepvállalásának problémáját is felveti. Bizonyos, hogy a márvány kisépítészeti együttes és a sírkamra szorosan öszszefügg egymással. E tekintetben a sírkamra kapcsán megfigyelt jelenségek már elkészült múvet, de legalábbis folyamatban lévő munkálatokat feltételeznek. Az átépítés kezdetei - a márványalkotások tekintetében ${ }^{88}$ bizonyosan - a király halála elé helyezhetők. Az 1204-es év ilyen szempontból terminus ante quem. Azon már lehet gondolkodni, hogy ez vajon egy egészében elkészült és befejezett múre vonatkozhatott, avagy akkor javában folytak még a kisarchitektúra és díszpadló körüli munkák. Másképp: a választás már egy átépülőben lévő, illetve átépített és megújított templomra eshetett, avagy az újjáépítés

86 SWEENEY 1993; SZABAdOS 1999a; SZABADOS 2000.

87 IPOLYI 1865, 118-119; PAULER 1899, II, 491-492; GYÖRFFY 1987, 85. Az uralkodó utolsó évének eseményeiről: KRISTÓ 1987, 1268-1272; SzABAdOS 1999a, 108-111. A kérdéshez újabb szempontokkal legutóbb: LASZLOVSZKY 2014, 132-133. (Inkább Katapán és más egyháziak befolyását, valamint Konstancia döntését, mintsem Imre megelőlegezett elhatározását látva a temetkezés helyének kiválasztásában.)

88 Ezekről részletesen lásd a 17. jegyzetben idézett munkákat. 
kezdetét épp az uralkodói/püspöki döntés, a temetkezés ténye válthatta ki? Az újjáépítés múve, annak terve, elgondolása Katapánhoz fúződhet; az, hogy az uralkodó milyen mértékben, módon vállalhatott részt, szerepet ebben (lásd Jób érsek és III. Béla esetét az esztergomi székesegyházzal) kérdéses, sok minden más mellett ezen is gondolkodhatunk. Azonban e mú mintaképválasztásának lehetséges iránya talán jelzésértékú lehet. Ezt az irányt jól jellemezheti Szent István legendáinak azon passzusa, amely az egri székesegyház alapítójaként és adományozójaként is számon tartott király ${ }^{89}$ - akinek kultuszát a székesegyház mellett állott, építészeti részletei nyomán a 13. század elejére valló prépostság is ápolta ${ }^{90}$ „csodálatra méltó" fehérvári múvéról szól. S amely az egyháza illő felszereléséról gondoskodó donátor toposzán túl a kórus falának felékesítését és padozatának márvánnyal való burkolását is idézhette az 1200 körüli utódok elé („opere mirifico, celaturis in chori pariete distinctis, pavimento tabulis marmoreis strato construere cepit..."). ${ }^{91}$ A szövegen túl ez a mú a kortársak, így a király és a székesegyháza újjáépítésén fáradozó püspök, a korábbi fehérvári prépost számá- ra is - átalakított formában, azonban néhány részletében a korábbit is őrző alkotás képével társuló - realitás lehetett. ${ }^{92}$ Nemcsak a márvánnyal ékesített kórus tekinthetó Fehérvár reminiszcenciájának, az egri elrendezés, a sír és a kórus körvonalazódó viszonya szintén egyfajta utalás lehet a királyi temetkezés „prototípusára”, elsősorban annak építészeti formáira. ${ }^{93}$ A rövid ideig uralkodó, atyja, III. Béla örökségéhez szorosan kötődő király temetkezése kapcsán felbukkanó „Fehérvár-idézet” talán nem független attól a jelenségkörtől - „historizmus” -, melyre az utóbbi időszak kutatása egyre hangsúlyosabban mutatott rá III. Béla „udvarának" és az 1200 körüli időszaknak a múvészetében. ${ }^{94} \mathrm{Ez}$ főként a Szent István személyével összefüggésbe hozott alkotásokhoz, különösen az uralkodói reprezentáció emlékeihez való viszonyban tưnik fel. Ez a kapcsolat talán a koronázási insigniumoknak (palást, korona), valamint a fehérvári bazilikának mint koronázási és temetkezési helynek a kitüntetett kezelésében ragadható meg leginkább, és többek között (a dinasztiában Szent István óta először és utoljára) III. Béla elsőszülött fiának és trónutódjának névadásában is tükröződött.
89 IV. Béla király egyetlen oklevélbe foglalja az egri egyház összes kiváltságát 1261. szeptember 9-én.

K. LÁTKÓCZKY 1997, 9. sz., 23-29. A privilégium eredetije nem maradt fenn, 1271-ben V. István, utóbb 1323. április 23-án Károly Róbert is átíratta. A tíz évvel késóbbi, 1271-es átirathoz lásd K. LÁTKÓCZKY 1997, 13. sz., 33-34. Ekkor V. István Lampert egri püspök kérésére átírta és megerősítette atyja, IV. Béla király 1261. szeptember 9-én kelt oklevelét.

$90 \mathrm{Az}$ egri székesegyház északi oldala mellett állott, Szent István királynak szentelt prépostsági templom építészeti maradványai, faragott részletei a 13. század elejére, elsó évtizedeire tehetők. Feltárásáról és építészeti maradványairól: LÉNÁRT 1987, 467-468; HAVASI 2006, 101-102; GIBER 2008, 46-49, 10-19. kép; HAVASI 2011, 39-40, 55-56. kép (további részletes irodalommal).

91 SRH II. 385, 417. Legenda Sancti Stephani regis maior és Legenda Sancti Stephani regis ab Hartvico episcopo conscripta.
92 Lásd a 80. jegyzetben idézett irodalmat.

93 A Szent István-sírra vonatkozó újabb kutatások tükrében (lásd különösen: Bı̇zó 2015) ez a felvetés bizonyosan árnyaltabb megítélésre szorul.

94 MArosi 2002, 269-298. 


\title{
FÜGGELÉK
}

Brezovay János 1794. március 20-án kelt levele Jankovich Miklóshoz ${ }^{1}$

\author{
Perillustris ac Generose Domine V[ice] Notarie \\ Domine Collega peculiariter colendissime!
}

\author{
Desideratam, ex Arcis Agriensis Orientalis Portae \\ Frontispicio, desumpto marmori insculptam In- \\ scriptionem, cuius procurandam hucusque \\ transmissionem, institutum in privatis meis \\ negotiis multiplex iter, sed et hyemalis tempesta- \\ tis pro describendo infortunitas distulerant, \\ nunc, semotis his obicibus, ad transversum hu- \\ jus Epistolae latus fideli manu transum- \\ pseram. \\ Illud pro singulari notitia adjicio: Men- \\ se hoc Martio duos infra vetustae Arcensis \\ Cathedralis Ecclesiae nunc dirutam cryptam \\ effossos haberi tumulos, quadratis lapidibus \\ expositos, in quorum uno Unius hominis \\ omnium membrorum ossa, et ferramenta \\ incineratae iam tumbae acclavata, reperie- \\ No 227. tormentales ferrei globi inhumati. \\ Credere est: tumulum hunc certe pro decore \\ exornatum, Emerici quondam Hungariae Regis \\ utique Agriae sepulti fuisse, alterum vero \\ tumulum Consorti ipsius praeparatum, sed \\ cum illa forte Budae mortua fuerit, ${ }^{2}$ tempo- \\ re oppugnationis Arcis Agriensis memoratis \\ globis repletum fuisse. Caeter[um] de his fe- \\ rendum Judicium aevi nostri Historiogra- \\ phis relinquendo, atque una in omnibus \\ dum Prae[tera]lta(?) D[ominatio] V[est]ra necesse habuerit, ne- \\ gotiis in his oris obventuris iterum Obsequium \\ ad serviendum offerrem, aestimatissimis \\ favoribus, et amititiae [...] maneo \\ Perillustris D[ominationis] \\ V[estr]ae servus humillimus
} bantur; in altero vero majores, octo circiter librarum graves, minores que, insimul

1 Országos Széchényi Könyvtár, Kézirattár, Fond 16/236, 10, 13. A levél átírásában és fordításában nyújtott segítségét Borossay Katalinnak ezúton is köszönöm. A levél említése: NAGY E. 1985, 145, illetve JANKOVICH 2002, 323, Kat. no. 364.

2 Imre felesége Aragóniai Konstancia (1182/1183 körül-1222), II. János aragón király és Kasztíliai Sancha idősebb lánya 1198-tól Imre, utóbb 1208/9-től II. Frigyes német-római császár (első) felesége volt. 1205-ben a gyermek III. László halála után végleg elhagyta Magyarországot. Frigyessel kötött házasságából született 1211-ben VII. Henrik. 1220-ban Frigyessel együtt Konstanciát is császárnévá koronázták Rómában. 1222. június 23-án hunyt el, és a palermói dómba temették el. SCHRAMM-MÜTHERICH 1962, 192-193 és Kat. 205, Abb. 205-206; WeHLi 1998, 10-17; HECHELHAMMER 2008, 123-125. (Die Ehe mit Kostanze von Aragón: 12091222); vö. még: SRH I. 463; PAULER 1899. II, 39, valamint Zsoldos 2005, 189; SzABAdOs 2002; 2009, $162-175$.

3 Brezovay János személyéről eddig közelebbit nem sikerült kideríteni. Az egerfarmosi származású Brezovay családnak az 1700-as évektől volt címeres nemesi levele, Brezovay János 1803-tól viselte a vármegyében a szolgabírói tisztet. SZEDERKÉNYI 1893, 321-322; KEMPELEN 1911, 438-439. Brezovay jegyző kollégájához írott levelének keltekor mindketten igen fiatalok voltak. Az a körülmény, hogy Brezovay ismeri Jankovichnak az 1780-as évek második felétől, az 1790-es évek elejétől a magyar múlt emlékei iránt megmutatkozó történeti érdeklődését, feltételezi személyes kapcsolatukat, amely talán a Pozsonyi Királyi Akadémiáról eredhetett. Az Akadémia elvégzése után a nemesi családok gyermekei rendszerint (tiszteletbeli) jegyzői hivatalt vállaltak vármegyéjükben. Jankovich Miklós 1793-1797 között állott a székesfehérvári megyeháza szolgálatában, míg Brezovay talán 1803-as szolgabírói kinevezése előtt múködhetett Egerben. Jankovich pályafutásához, tanulmányaihoz: BERLÁsz 1985, 27-31. 


\begin{abstract}
ARCE. AGRIEN. MONTIS. IMMINENTIS. INIU
RIA LABORANTE. ANT. VERANCIUS. NAT. DAL. MATA. PATR. SIBENICEN. ANTIST. AGRIEN. MOLEM. HANC ILLI. PER. TOTAM. EIUSD. AR. LATITUDINEM. IN. MEDIO. POS. RUDERIBUS. Q. EXCITATAM. ET. UTRIN Q. MURO. ALTITUDINE QUANTUM. F. POT. PARI. COM PLEXAM. REGNAN. IN. HUNG. D. OP. Q. CAES. FERD. PRI. IMP. ROM. AUG. CLEMENTE. VERO REGNI. ${ }^{4}$ PROVI SORE. SUO. PROCURAN. OPPONI. F. AN. D. M. D. LX. ${ }^{5}$
\end{abstract}

Nemzetes és vitézlő Aljegyző Uram, kiváltképpen tiszteletreméltó Kollégám!

A kérdéses feliratot, amely az egri vár keleti kapujának homlokzatából kivett márványba van vésve, melynek átküldését eddig magánügyeim bonyolódása és a téli időjárás írásra való alkalmatlansága is késleltette, most, hogy ezek az akadályok elhárultak, ennek a levélnek a hátoldalára híven áttettem.

Egyetlen megjegyzést fúzök hozzá: e márciusban a régi egri várszékesegyház most lebontott kriptája alatt ki lett ásva két, kváderkövekkel kirakott sír, melyek közül az egyikben egy ember teljes csontvázát és egy már elporladt koporsó vasalatait találtuk, a másikban pedig nagyobb, kb. nyolc font súlyú és kisebb ágyúgolyókat eltemetve, összesen 227 db-ot.

Azt kell hinnünk, hogy ez a valóban szépen díszített sír Imréé, Magyarország egykori királyáé volt, minthogy öt Egerben temették el, a másikat pedig hitvesének készítették, de mivel ő történetesen/ talán Budán halt meg, az egri vár ostroma idején töltötték be a fent említett golyókkal. Egyébként pedig meghagyva korunk történetíróinak, hogy ezekről véleményt mondjanak, [...] maradok nemzetes uraságodnak alázatos szolgája,

Brezovay János s. k.

Fordította: Borossay Katalin

\title{
IRODALOM
}

AutenRIETH, HANS Peter

1988 Über das Feinrelief in der romanischen Architektur. In: Much, F. J. (Hrsg.): Baukunst des Mittelalters in Europa: Festschrift für Hans Erich Kubach zum 75. Geburtstag. Stuttgart, 27-70.

AZZOLA, KARL FRIEDRICH

1986 Zur Ikonographie des Kreuzes auf Kleindenkmälern des Hoch- und Spätmittelalters im deutschen Sprachraum. In: Zimmermann, H. (Hrsg.): Deutsche Inschriften. Mainz, 11-37.

BAKAY KORNÉL

1975 Második jelentés a somogyvári bencés apátság feltárásáról (1974-1975), (Zweiter Bericht über die Freilegung der Benediktinerabtei von Somogyvár in den Jahren 1974-1975.). Somogy Megyei Múzeumok Közleményei (Kaposvár) 2, 191-206.

2011 Somogyvár. Szent Egyed-monostor. A somogyvári bencés apátság és védmúveinek régészeti feltárása (Historical recapitulation). 1972-2009. Budapest.

Bellus IbOlya-KRistó GyUla (ford.)

2001 Thuróczy János: A magyarok krónikája. In: Thuróczy János: A magyarok krónikája. Rogerius mester: Siralmas ének. Millenniumi Magyar Történelem. Források. Budapest, 9-397.

BENKŐ ELEK

2014 Gertrúd királyné sírja a pilisi ciszterci monostorban. In: Majorossy J. (szerk.): Egy történelmi gyilkosság margójára. Merániai Gertrúd emlékezete, 1213-2013. Szentendre, 173-188.

4 Az N fölé Brezovay egy Y-t írt, az aláhúzás tőle való.

5 A levél elején említett, az egri vár „keleti kapujának” homlokzatáról ekkoriban leemelt, Verancsics Antal építkezését megörökíto, 1560-ban készült feliratos „márványtábla” szövegének átirata a levél hátoldaláról. A feliratos tábla eredetije jelenleg ismeretlen. Ezzel kapcsolatban köszönöm Mikó Árpád és Lővei Pál segítségét. Verancsics mecénási tevékenységéről lásd Mikó 2015, 17-27. 
ifj. BARTA JÁNOS-BARTA GÁBOR

1993 III. Béla király jövedelmei. (Megjegyzések középkori uralkodóink bevételeiről.) Századok (Budapest) 127, 413-449.

BERLÁSZ JENŐ

1985 Jankovich Miklós pályaképe és könyvtári gyújteményei. In: Belitska-Scholtz H. (szerk.): Jankovich Miklós, a gyújtő és mecénás (1772-1846). Budapest, 27-31.

BERTÉNYI IVÁN (szerk.)

2000 Magyar történeti szöveggyújtemény. 1000-1526. Budapest.

BicZÓ PIROSKA

1999 Érdy János leletmentésének tudományos jelentősége. In: Cserményi V. (szerk.): 150 éve történt. III. Béla és Antiochiai Anna sírjának fellelése. Székesfehérvár, 16-23.

2001 Archäologische Beobactungen zur Baugeschichte der Stiftskirche Unserer Lieben Frau zu Székesfehérvár. Acta Historiae Artium (Budapest) 42, 283-295.

2002 A „lelet” mint gyújteményi tárgy. Proveniencia-problémák. In: Jankovich 2002, 24-29.

2004a Az Anjou-temetkezések kutatástörténete. In: Deák Z. (szerk.): Magyar királyi és főrendi síremlékek. Budapest, 32-35.

2004b A prépostsági templom déli oldalán feltárt gótikus kápolna. In: Deák Z. (szerk.): Magyar királyi és főrendi síremlékek. Budapest, 48-57.

2011a A székesfehérvári Szúz Mária prépostsági templom déli oldalának régészeti feltárása (The archaeological excavation of the southern side of the Virgin Mary Provost Church of Székesfehérvár). In: Kerny, T.Smohay, A. (szerk.): Károly Róbert és Székesfehérvár (King Charles Robert and Székesfehérvár). 2011, 139-170.

2011b Das königliche Marienstift zu Székesfehérvár im Lichte der neueren Grabungen. Acta Historiae Artium (Budapest) 52, 5-29.

2015 Szent István sírja a székesfehérvári Szúz Mária-prépostság templomában (The burial place of King Stephen the Saint in the provostal church of the Virgin Mary, Székesfehérvár). In: Benkő E.-Orosz, K. (szerk.): In medio regni Hungariae. Régészeti, múvészettörténeti és történeti kutatások „,az ország közepén" (Archaeological, art historical, and historical researches 'in the middle of the kingdom'). 299-323.

2016 Az Árpád-házi királysírok. Budapest.

Biczó, PirosKa-Tóth, MELINDA

2000 Das Marienstift Stuhlweissenburg. In: Wieczorek, A.-Hinz, H. M. (Hrsg.): Europas Mitte um 1000. II. Stuttgart, 621-624. (A magyar nyelvú pótkötetben: 388-390.)

\section{BITSKEY ISTVÁN}

1997 Püspökök, írók, könyvtárak. Egri főpapok irodalmi mecenatúrája a barokk korban. Studia Agriensia 16. Eger.

BODÓ BALÁZS

2010 A pécsváradi bencés monostor építéstörténete (The architectural history of the Benedictine Monastery at Pécsvárad as reflected in the latest research). In: Benkő E.-Kovács Gy. (szerk.): A középkor és kora újkor régészete Magyarországon. I. (Archaeology of the Middle Ages and the Early Modern Period in Hungary). Budapest, 349-383.

BONFINI, ANTONIO

1936 Rerum ungaricum decades. Fógel, I.-Iványi, B.-Juhász, L. (eds): Lipsiae, 81.

BORGOLTE, MiCHAEL

1985 Stiftergrab und Eigenkirche. Ein Begriffspaar der Mittelalterarchäologie in historischer Kritik. Zeitschrift für Archäologie des Mittelalters 13, 27-38.

BUZÁS GERGELY

2014 A kalocsai érseksír azonosítása, Archaeologia, Altum Castrum Online 2014 http://pannonhalma70-74. gportal.hu/portal/pannonhalma70-74/upload/251068_1397808574_08875.pdf (Letöltés: 2017. 03. 22.)

Chevalier, Pascale-Maquet, Alette

2004 La fouille des tombeaux des Saint Abbés de Cluny, Mayeul et Odilou et les pélerinages á Souvigny. Bulletin Monumental (Paris) 162:2, 87-100.

CSEMEGI JÓZSEF

1935 Az egri várszékesegyház jelentősége a XII. században. Archaeologiai Értesítő (Budapest) 48, 217-223.

DAHM, FRIEDRICH

1998 Tumba für Herzog Friedriech II. In: Geschichte der Bildenden Kunst in Österreich. Band I. Früh- und Hochmittelalter. München-New York, Kat. 140, 398-399.

\section{DERCSÉNYI DEZSÓ}

1934 A somogyvári Szent Egyed-apátság maradványai. Budapest.

1943 A székesfehérvári királyi bazilika. Budapest.

DÉTSHY MiHÁLY

1964 Az egri várszékesegyház építéstörténetének okleveles adatai, Múvészettörténeti Értesítő (Budapest) 13, 1-19. 
DHA I.

1992 Györffy, Gy. (ed.): Diplomata Hungariae antiquissima accedunt epistolae et acta ad historiam Hungariae pertinentia. I. 1000-1131. Budapest.

DobSZAY LÁsZló (ed.)

2000 Liber ordinarius Agriensis. Musicalia Danubiana Subsidia 1. Budapest.

ENGEL PÁL

1987 Temetkezések a középkori székesfehérvári bazilikában. Századok (Budapet) 121, 613-637.

F. VATTAI ERZSÉBET

1966/1967 A margitszigeti korona és gyưrú (Die Krone und der Ring von der Margareteninsel). Folia Archaeologica

FODOR LÁSZLÓ (Budapest) 18, 123-136.

2001 Jelentés az egri vár területén feltárt román kori székesegyház déli kápolnájában lévő korai keresztelőegyház (rotunda) leletmentő régészeti kutatásáról. Múemlékvédelmi Szemle 11:1-2, 209-210.

FOERK ERNÓ

1915 A kalocsai érseki székesegyház. Budapest.

FÜGEDI ERIK

1986 Ispánok, bárók, kiskirályok. Budapest.

1991 „Sepelierunt corpus eius in proprio monasterio.” A nemzetségi monostor. Századok (Budapest) 125, 35-67.

GEREVICH TIBOR

1938 Magyarország románkori emlékei. Magyarország múvészeti emlékei. I. Budapest.

GIBER MiHÁLY

2008 Adatok az egri püspökvár középkori építéstörténetéhez (Observations on the architectural history of the medieval episcopal castle). Agria. Az egri Dobó István Vármúzeum Évkönyve (Eger) 44, 37-80.

GYÖRFFY GYÖRGY

1970 Becket Tamás és Magyarország. Filológiai Közlöny (Budapest) 16, 153-154.

1982 Megjegyzések Gyurkó János cikkéhez. Múemlékvédelem (Budapest) 26:1, 67.

1987 Az Árpád-kori Magyarország történeti földrajza. III. Heves, Hont, Hunyad, Keve, Kolozs, Komárom, Krassó, Kraszna, Küküllő megye és Kunság. Budapest.

HAGENDER, OTHMAR

1997 Die Register Innocenz' III. Band 7. Wien.

HAVASI KRISZTINA

2003 „1200 körüli” faragványcsoport töredékei a középkori egri székesegyházból (Early 13th century carved fragments from Eger's medieval cathedral). Agria. Az egri Dobó István Vármúzeum Évkönyve (Eger) 39, 113-186.

2004 A középkori egri székesegyház emlékei a XII-XIII. század fordulójáról. Kézirat. ELTE BTK Múvészettörténeti Intézet. (Szakdolgozat. Témavezető: Tóth Sándor.)

2006 Reneszánsz márványdombormú töredékei az egri várból (Fragments of a Renaissance marble relief from Eger Castle). Múvészettörténeti Értesítő (Budapest) 55, 95-117.

2009 Az egri Szent János Evangelista székesegyház: Imre király temetkezőhelye. Tóth Cs.-Sarobe, R. (szerk.): Királylányok messzi földről. Magyarország és Katalónia a középkorban. Budapest, 270-271.

2011 A középkori egri székesegyház az 1200-as évek elején. Király, püspökök és újjáépülő székesegyházak a korabeli Magyarországon. I-II. PhD-disszertáció (ELTE BTK Múvészettörténeti Intézet), Budapest.

2015 A kácsi bencés apátság román kori kőfaragványai (Romanesque carved stone fragments of a Benedictine Abbey of Kács). Múvészettörténeti Értesítő (Budapest) 64, 5-43.

HAVASI KRISZTINA-MAROSI ERNŐ-SZAKÁCS BÉlA ZsOLT

2012 Havasi Krisztina „A középkori egri székesegyház az 1200-as évek elején. Király, püspökök és újjáépülő székesegyházak a korabeli Magyarországon” címú PhD-értekezésének vitája. Múvészettörténeti Értesítő (Budapest) 61, 157-172.

HECHELHAMMER, BODO

2008 Friedrich II. und seine Ehefrauen, In: Fansa, M.-Ermete, K. (Hrsg.): Kaiser Friedrich II. (1194-1250). Welt und Kultur des Mittelmeerraums. Mainz am Rhein, 123-131.

HENSZLMANN IMRE

1884 A nagy-váradi kettős székesegyház. In: Bunyitai V. (szerk.): A váradi püspökség története alapításától a jelen korig. Harmadik kötet. Nagyvárad. Reprint, 168-174.

HeRvay F. LEVENTE O.Cist.

2001 A bencések és apátságaik története a középkori Magyarországon. Történeti katalógus. In: PARADISUM PLANTAVIT 462-547.

HUCKER, BERND URLICH

2001 Stauferzeitliche Zisterziensergründunen und Stiftergräber. In: Knefelkamp, U. (Hrsg.): Zisterzienser. Norm, Kultur, Reform - 900 Jahre Zisterzienser. (Schriftenreihe des Interdisziplinären Zentrums für Ethik an der Europa-Universität Viadrina, Frankfurt am Oder) Berlin-Heidelberg-New York, 287-292. 
HuMANN, GEORG

1893 Zur Geschichte der Kreuzaltare, Zeitschrift für Christliche Kunst (Heidelberg) 6, 73-82.

INCHOFER, MELCHIOR

1644 Annales ecclesiastici regni Hungariae. Romae.

IPOLYI ARNOLD

1865 Az egri megye Sz. János apostol és evangelistáról nevezett régi székesegyháza az egri várban. In: Emlékkönyv Kis-Apponyi Bartakovics Béla érsek Aranymiséjének ünnepére. Eger, 95-171.

JANKOVICH

2002 Mikó Á. (szerk.): Jankovich Miklós (1772-1846) gyújteményei. Budapest.

K. LÁTKÓCZKY ERZSÉBET

1997 Árpád-kori oklevelek a Heves Megyei Levéltárban. Fordította, jegyzetekkel ellátta: K. Látkóczki E. Eger.

KATONA IsTVÁN

2001 A kalocsai érseki egyház története. I. Ford. Takács J. Kalocsa.

KAUTZSCH, RUdOLF

1944 Der romanische Kirchenbau im Elsass. Freiburg in Breisgau.

KÁRPÁti JÁNOS

2010 Az egri püspökvár. Eger.

KERNY TERÉZIA

2006 Zsigmond király temetése és temetkezőhelye. In: Takács I. (szerk.): Sigismundus rex et imperator.

Múvészet és kultúra Luxemburgi Zsigmond korában 1387-1437. Budapest, 475-479.

KEMPELEN BÉLA

1911 Magyar nemesi családok. II. Budapest.

KMTL

1994 Kristó Gy. (fószerk.)-Engel P.-Makk F. (szerk.): Korai magyar történeti lexikon. Budapest.

KNAUZ NÁNDOR

1865 Magyar érsek- és püspökségek jövedelmei. Magyar Sion III, 552-557.

KOMM, SABINE

1990 Heiligengrabmäler des 11. und 12. Jahrhunderts in Frankreich. Untersuchung zur Typologie und Grabverehrung. Worms.

Koszta LÁsZló

1993 A ciszterci rend története Magyarországon kolostoraik alapítása idején 1142-1270. Magyar Egyháztörténeti Vázlatok (Budapest) 118-125.

2001 A váci püspökség alapítása. Századok (Budapest) 135, 363-375.

KovÁCs BÉlA

1966 Elpusztult kolostorok Heves megyében (Covents médiévaux disparus dans le comitat Heves). Agria. Az egri Dobó István Vármúzeum Évkönyve (Eger) 4, 76-79.

1968 Adatok Feldebró történetéhez. Múvészettörténeti Értesító (Budapest) 17, 124-125.

1987 Az egri egyházmegye története 1596-ig. Eger.

KOVÁCs ÉvA

1982 A gótikus ronde-bosse zománc a budai udvarban. Múvészettörténeti Értesítő (Budapest) 31, 89-94.

KovALOVSZKI JÚLIA

1981 A feldebrői templom régészeti kutatása. In: Képzőmúvészeti emlékek védelme. Az egri nyári egyetem előadásai. Eger, 39-42.

1987 Feldebró-plébániatemplom. Tájak, Korok, Múzeumok Kiskönyvtára 283. Budapest.

KOZÁK KÁROLY

1973 A középkori egri székesegyház feltárása és építéstörténete. Az Egri Vár Híradója 9-10, 29-34.

1981 Az egri vár története. Vezetó a gótikus palota állandó kiállításához. Eger.

1989 Eger. Püspökvár. (Tájak, Korok, Múzeumok Kiskönyvtára 12.) Budapest.

KOZÁK KÁROLY DOK.

1968 Eger, várásatás. 1968. Jelentés az egri várban végzett feltárásról 1968. Ásatási napló. Gépirat. Forster Központ Tervtár, ltsz. D25576.

1969 Eger, várásatás. 1969. Jelentés az egri várban végzett feltárásról. 1969. Ásatási napló. Gépirat, 1969. Magyar Nemzeti Múzeum, Régészeti Adattár.

1974 Eger, várásatás. 1974. Jelentés az egri várban végzett feltárásról. 1974. Ásatási napló. Gépirat, 1974. Magyar Nemzeti Múzeum, Régészeti Adattár.

KoZÁK KÁROLY-SEDLMAYr JÁNOS

1987 Az egri vár középkori kőtára. Eger.

KRALOVÁNSZKY ALÁN

1988 Szent István király székesfehérvári sírjának és kultuszhelyének kérdése. In: Glatz F.-Kardos J. (szerk.): Szent István és kora. Budapest, 166-172.

1989 Szent István király székesfehérvári sírja és kultuszhelye (Grab des König Hl. Stephan und Ort seiner Verehrung in Székesfehérvár/Stuhlweißenburg). Folia Archaeologica (Budapest) 40, 155-173. 
KRISTÓ GYULA

1987 Imre és III. László. In: Székely Gy. (főszerk.): Magyarország története II. Előzmények és magyar történet 1242-ig. Budapest, 1268-1272.

2000 Utószó. In: Küküllei János: Lajos Király Krónikája. Névtelen szerző: Geszta Lajos királyról. Millenniumi Magyar Történelem. Források. Budapest, 89-117.

KUBINYI ANDRÁS

1975 Királyi kancellária és udvari kápolna Magyarországon a XII. század közepén. Levéltári Közlemények (Budapest) 47:1, 59-117.

LASZLOVSZKY JÓZSEF

2014 Merániai Gertrúd sírja a pilisi apátságban. Uralkodói temetkezések ciszterci kolostorokban a Magyar Királyságban. In: Majorossy J. (szerk.): Egy történelmi gyilkosság margójára. Merániai Gertrúd emlékezete, 1213-2013. Szentendre, 125-148.

LÉNÁRT ANDOR

1987 Az egri várbeli székesegyházak feltárásának ásatási naplója (1928-1938), Agria. Az Egri Múzeum Évkönyve 23, 431-471.

LŐVEI PÁL

2004 Az Anjou-síremlékek újonnan előkerült töredékeiről. In: Deák Z. (szerk.): Magyar királyi és főrendi síremlékek. 2004, 72-85.

2010 Renaissance in Red and White. The Use of Coloured Stone in Hungary at the Turn of the 16th Century. In: Varga, L.-Beke, L.-Jávor, A.-Lővei, P.-Takács, I. (eds): Bonum ut pulchrum. Essays in Art History in Honour of Ernó Marosi on His Seventieth Birthday. 433-442.

2011 Aszékesfehérvári Anjou-síremlékek az újabb töredékek tükrében (On the Anjou shrines of Székesfehérvár considering the newly found fragments). In: Kerny, T.- Smohay, A. (ed.): Károly Róbert és Székesfehérvár (King Charles Robert and Székesfehérvár). 2011, 171-187.

LőveI PÁl-WEISZ BOGLÁRKA

2016 A gazdaság- és pénzügyigazgatás szereplőinek szórványos síremlékei a középkori Magyarországon. In: Weisz, B. (szerk.): Pénz, posztó, piac. Gazdaságtörténeti tanulmányok a magyar középkorról. Magyar Történelmi Emlékek, Értekezések. 217-263.

MAKK FERENC

2007 Lukács (†1181). Kőszeghy P. (főszerk.): Magyar Múvelődéstörténeti Lexikon 7, 126-127.

MAROSI ERNŐ

1984 Die Anfänge der Gotik in Ungarn. Esztergom in der Kunst des 12-13. Jahrhunderts. Budapest.

1986 Megjegyzések a középkori magyarországi múvészet liturgiai vonatkozásaihoz. In: Tüskés G. (szerk.): „Mert ezt Isten hagyta...” Tanulmányok a népi vallásosság köréból. Budapest, 88-116.

1998 Österreich und Gotikrezeption. Zwei Bücher über die Kunst der letzten Babenberger und die Edition eines Klassikers. Acta Historiae Artium (Budapest) 40, 117-123.

2000a Das Grab des Heiligen Stephan in Stuhlweissenburg. In: Wieczorek, A.-Hinz, H. M. (Hrsg.): Europas Mitte um 1000. II. Stuttgart, 625-627.

2000b Christliche Architektur in Ungarn. In: Wieczorek, A.-Hinz, H. M. (Hrsg.): Europas Mitte um 1000. II. Stuttgart, 615-616.

2000c "Quam qui vidit, testimonium veritati verbum nostrorum perhibet”. Megjegyzések Szent István prépostsági templomának képéhez elbeszélő forrásainkban. In: Piti F. (szerk.): „Magyaroknak eleiről”. Ünnepi tanulmányok a hatvan esztendős Makk Ferenc tiszteletére, Szeged, 349-363.

2002 Historizmus az 1200 körüli múvészetben Magyarországon. In: Székfoglalók a Magyar Tudományos Akadémián. Társadalomtudományok. Budapest 2005, 269-298.

MAROSI ERNŐ-WEHLI TÜNDE

1997 Az Árpád-kori múvészet atlasza. Budapest.

MÁTYÁs rec.

1900 Ismeretlen szerző [Pauler Gyula?]: Szent László és Imre királyok végnapjai és II. Endre életévei, fogsága és temetése. Olvastatott az MTA II. osztályának 1900 jún. 11-én tartott ülésén. Mátyás Flórián r. tagtól. Értekezések a történeti tudományok köréból, XIX. kötet 1. szám. Századok (Budapest) 34, 738-740.

MEIER, THOMAS

1998 Zwischen Stiftern und Heiligen - die Saliergräber im Speyerer Dom. Beiträge zur Mittelalterarchäologie in Österreich (Wien) 14, 37-48.

2002 Die Archäologie des mittelalterlichen Königsgrabes im christlichen Europa. Mittelalter-Forschungen 8. Stuttgart.

MeZey LÁsZló

1971 A Pray-kódex keletkezése. Magyar Könyvszemle 8:2-3, 109-123.

MEZŐ ANDRÁS

2003 Patrocíniumok a középkori Magyarországon. METEM Könyvek 40. Budapest.

$\mathrm{MHH}$ 
1870 Monumenta Hungariae Historica. Scriptores. XX. Verancsics Antal összes munkái. IX. Vegyes levelek. 1563-1569. Pest.

MIKÓ ÁRPÁD

2015 Egy humanista mecénás a 16. század közepén Magyarországon. Korunk (Budapest) 3:1, 17-27.

MÖBIUS, FRIEDRICH

1984 Die Chorpatrie der westeuropaischen Klosterkirche zwischen 8. und 11. Jahrhundert. Kulturgeschictliche Voraussetzungen, liturgischer Gebrauch, soziale Funktion. In: Möbius, F.-Schubert, E. (Hrsg.): Architektur des Mittelalters. Funktion und Gestalt. Weimar, 9-41.

NAGY ÁRPÁD

1968 A kalocsai XI. századi érseksír. Múvészettörténeti Értesítő (Budapest) 17, 112-123.

1969 Jegyzetek az egri püspökség XI. századi történetéről. Az Egri Vár Híradója 8, 25-30.

NAGY EMESE

1978 Kőfaragástechnika a középkorban. In: Tóth M.-Marosi E. (szerk.): Árpád-kori kőfaragványok. Kiállítási katalógus. Székesfehérvár, 52-58.

1985 Jankovich Miklós régészeti és múemléki tevékenysége. In: Belitska-Scholtz H. (szerk.): Jankovich Miklós, a gyújtő és mecénás (1772-1846). Budapest, 122-153.

NAGY GÉZA BALÁZS

2006 Gondolatok Imre király és az egri püspökök sírjairól. Az Egri Vár Híradója 38, 99-109.

NAGY LÁSZLÓ

2015 Beszámoló az egri várban 2014-ben végzett régészeti munkákról. Castrum. A Castrum Bene Egyesület Hírlevele (Budapest) 18, 59-103.

ORDINARIUS

Ordinarius secundum veram notulam sive rubricam alme ecclesie Agriensis de observatione divinorum officiorum et horarum canonicarum. Közzétette: Kandra K. In: Adatok az Egri Egyházmegye történelméhez. III/3.

OSWALD, FRIEDRICH

1969 In medio Ecclesiae. Die Deutung der literarischen Zeugnisse im Lichte archäologische Funde,

PANNONIA REGIA

Frühmittelalterliche Studien (Münster) 3, 313-326.

1994 Mikó Á.-Takács I. (szerk.): Pannonia Regia. Múvészet a Dunántúlon 1000-1541. Budapest.

PAPP SZILÁRD

2001a Pannonhalma és Somogyvár. Bencés reform és építészet a 15-16. század fordulóján. In: PARADISUM PLANTAVIT 289-315.

2001b Somogyvár. A templom és a kolostor épületei. In: PARADisum Plantavit 350-353.

PARADISUM PlantaViT

2001 Takács I. (szerk.): Paradisum Plantavit. Bencés monostorok a középkori Magyarországon. Pannonhalma.

PATAKI JÁNOS

é.n. Eger város múltjára vonatkozó középkori oklevelek és oklevélmásolatok. Dobó István Vármúzeum, Régészeti Adattár, 77-79.

PAULER GYULA

1899 A magyar nemzet története az Árpád házi királyok alatt. I-II. Budapest.

PROHÁSZKA PÉTER

2011 Észrevételek a CIL 3349 (RIU 1504) székesfehérvári felirathoz egy levél tükrében. In: Kovács, P.-Fehér, SCHMIDT, KARL

B.-Szabó Á.: Studia Epigraphica Pannonica (Budapest) 3, 56-63.

1984 Die Sorge der Salier um ihre Memoria. Zeugnisse, Erwägungen und Fragen. In: Schmidt, K. - Wollasch, J. (Hrsg.): Memoria. Der geschichtliche Zeugnisvert des Liturgischen Gedenkens im Mittelalter. Münstersche Mittelalter-Schriften Bd. 48. München, 666-726.

SCHMITTH, NICOLAUS

1768 Episcopi Agrienses. I-III. Tyrnavie.

SCHRAMM, PERCY ERNST-MÜTHERICH, FLORENTINE

1962 Schramm, P. E.-Mütherich, F. (Hrsg.): Denkmale der deutschen Könige und Kaiser. I. Ein Beitrag zur Herrschergeschichte von Karl dem Großen bis Friedrich II. 768-1250. München.

SCHWARZ, MARIO

1998a Heiligenkreuz, Zisterzienserabtei. In: Fillitz, H. (Hrsg.): Geschichte der Bildenden Kunst in Österreich. Band I. Früh- und Hochmittelalter. München-New York, Kat. 47, 256-257, 299-301.

1998b Lilienfeld, Zisterzienserabtei. In: Fillitz, H. (Hg.): Geschichte der Bildenden Kunst in Österreich. Band I. Früh- und Hochmittelalter. München-New York, Kat. 69, 299-301.

SEEGER, ULRIKE

1997 Zisterzienser und Gotikrezeption: Die Bautätigkeit des Babenbergers Leopold VI. in Lilienfeld und Klosterneuburg. (Kunstwissenschaftliche Studien 69.) München. 
SOLYMOSI LÁSZLÓ

2012 Egy tévedés nyomában. Szent László király somogyvári temetésének legendája. In: Illés P. A.-JuhászLaczik A. (szerk.): Örökség és küldetés. Bencések Magyarországon. Múvelődéstörténeti Múhely. Rendtörténeti konferenciák. 7. Budapest, 151-171.

SRH I-II

1938 Szentpétery, E. (ed.): Scriptores rerum hungaricum tempore ducum regumque stirpis Arpadianae

SUGÁR ISTVÁN gestarum. I-II. Budapest (1999 reprint).

1984 Az egri püspökök története. Budapest.

SWEENY, JAMES Ross

1993 III. Ince és az esztergomi érsekválasztási vita. A Bone Memorie II. dekretális történeti háttere. Aetas (Budapest) 8:1, 147-169.

SZABADOS GYÖRGY

1999a Imre és András. Századok (Budapest) 133, 85-111.

1999b Imre király életidejéről. Acta Historica (Szeged) 110, 11-19.

2000 Egy elmaradt keresztes hadjáratról. Magyar-szentszéki kapcsolatok 1198-1204 között. In: Piti F. (szerk.): „Magyaroknak eleiről”. Ünnepi tanulmányok a hatvan esztendős Makk Ferenc tiszteletére. Szeged, 473-492.

2002 Imre király házassága, aranybullája. Századok (Budapest) 136, 341-350.

2009 Tóth Cs.-Sarobe, R. (szerk.): Aragóniai Konstancia magyar királyné. In: Királylányok messzi földről. Magyarország és Katalónia a középkorban. Budapest, 162-175.

SZAKÁCS, BÉLA ZSOLT

2002 Remarks on the Filigree of the Holy Crown of Hungary. Acta Historiae Artium (Budapest) 43, 52-61.

2005 The Research on Romanesque Architecture in Hungary: a Critical Overview of the Last Twenty Years. Arte Medievale (Roma) IV:2, 31-44.

2006 Cathedrals in the Early XIII ${ }^{\text {th }}$ Century in Hungary. In: Rusu, A. A. (ed.): Secolul al XIII-lea pe meleagurile locuite de către români. Cluj-Napoca, 179-191.

2010 Dombó és a korai altemplomok Magyarországon. In: Kollár T. (szerk.): Építészet a középkori DélMagyarországon. Tanulmányok. Budapest, 671-715.

SZEDERKÉNYI NÁNDOR

1893 Heves Vármegye története. IV. 1687-1867-ig. Eger.

SZENTPÉTERY IMRE

1923 Az Árpád-házi királyok okleveleinek kritikai jegyzéke. I. Budapest 1923.

SZÉKESFEHÉRVÁR

1934 A Zágrábi és a Váradi krónika egymáshoz való viszonya. Századok 68, 410-425.

1982 Marosi E.-Tóth M.-Wehli T. (szerk.): Mưvészet I. Lajos király korában 1342-1382. Kiállítási katalógus. Székesfehérvár.

SZMRECSÁNYI MiKLÓs

1932 Az egri érseki líceum lapidáriumának tárgymutatója. Eger 1932.

TAKÁCS IMRE

1994 Gertrudis királyné síremléke. PANNONIA REGIA 248-251.

1998 Fragmente des Grabmals der Königin Gertrudis. In: Vorwerk, U.-Schurr, E. (Red.): Die AndechsMeranier in Franken. Europäisches Fürstentum im Hochmittelalter. Mainz , 103-109.

2014 A Gertrúd-síremlék rekonstrukciójának kérdései. In: Majorossy J. (szerk.): Egy történelmi gyilkosság margójára. Merániai Gertrúd emlékezete, 1213-2013. Szentendre, 189-202.

THOROCZKAY GÁBOR

2009 Szent István egyházmegyéi - Szent István püspökei. In: Thoroczkay G.: Írások az Árpád-korról. Történeti és historiográfiai tanulmányok. Budapest, 33-50.

TÓTH ENDRE

2006 III. Béla vagy Kálmán? (A székesfehérvári királysír azonosításáról). Folia Archaeologica (Budapest) 52, 141-159.

TÓTH MELINDA

1981 A feldebrői falképek. In: Képzőmúvészeti emlékek védelme. Az egri nyári egyetem előadásai. Eger, 31-35.

1987 Die Umbauung des Heiligkreuz-Altars in der Kathedrale zu Pécs. In: Möbius, F.-Schubert, E. (Hrsg.): Skulptur des Mittelalters. Funktion und Gestalt. Weimar, 81-108.

1992 A somogyvári bencés apátság temploma az Árpád-korban. In: Magyar K. (szerk.): Szent László és Somogyvár. Kaposvár, 222-226.

1994 A pécsi székesegyház kőszobrászati díszítése a román korban. In: PANNONIA REGIA 123-130.

TóTH SÁNDOR

1994 A székesfehérvári szarkofág és köre. In: PANNONIA Regia 82-86. 
2001 A 11-12. századi Magyarország Benedek-rendi templomainak maradványai. In: PARADISUM PLANTAVIT 229-226.

UNTERMANN, MATTHIAS

2001 Forma Ordinis. Die mittelalterliche Baukunst der Zisterzienser. (Kunstwissenschaftlichen Studien). München-Berlin.

WEHLI TÜNDE

1998 Konstancia királyné a palermói dómban. Ars Hungarica (Budapest) 25:1, 10-17.

WEINFURTER, STEPHAN

2005 Speyer und die Könige in Salischer Zeit. In: Ehlers, C.-Flackenecker, H. (Hg.): Geistliche Zentralorte ZsOLDOS ATTILA zwischen Liturgie und Architektur, Gottes und Herrscherlob: Limburg und Speyer. Göttingen, 157-173.

2005 Az Árpádok és asszonyaik. A királynéi intézmény az Árpádok korában. Társadalom- és múvelődéstörténeti tanulmányok 36. Budapest.

2011 Magyarország világi archontológiája. 1000-1301. Budapest.

“CUIUS CORPUS REQUIESCIT IN ECCLESIA AGRIENSI..."

\section{KRISZTINA HAVASI}

The possible burial of King Emerich (r. 1196-1204) in Eger in 1204 has been an oft-discussed issue since the accounts written by the antiquarians who keenly monitored the demolition of Eger Cathedral in the 18th century. Among the medieval literary sources, the burial of the king in this location is mentioned in the Zagreb Chronicle and a 14th-century chronicle written some time later.

According to archival records, a vaulted burial chamber constructed of ashlars and a chest tomb of stone slabs dated to the late medieval period at the time was uncovered under the floor in the centre of the cathedral's main nave in 1937. On the testimony of a few documents (photos, survey records), the burial chamber was also investigated in the course of the excavations conducted by Károly Kozák in the late 1960s, although the chamber is barely mentioned in the field documentation and the other excavation records. The present study reviews the historical and archaeological evidence on the prominently located burial chamber, complemented with the findings of the investigation and documentation of this structure between 2004 and 2006, which in part remained incomplete.

On the testimony of the archival records and the observations made during the 1937 excavation, the chamber was opened and looted in the mid-1750s at the latest. The burial chamber was aligned to the main nave's central axis and lay in the western end of the longhouse, between two western pairs of Romanesque pillars. (It would appear that the western extension of the 12th-century longhouse was slightly larger and had a more complex layout than previously assumed.) The location of the burial chamber conformed to the criterion of in medio ecclesiae/in medio domus. A flight of steps (restored in the 1970s) led to the entrance in the western wall of the ashlar burial chamber with segmental barrel wall. A chest tomb of stone slabs was set in the middle of the chamber.
The floor of the burial chamber was broken through in the 18th century at the latest. Delicate marble plaques could be noted between the fine-grained calcareous mortar between the ashlars, and greyish and blackish marble fragments and delicate worked marble plaques were found immediately below the lowermost course of stones and in the mortar bedding of the ashlars and the threshold stone. Similar marble fragments lay underneath the stone slabs of the chest tomb's longitudinal side. In 1937, these marble fragments were interpreted as the remains of a marble mosaic floor that had partially or wholly covered the burial chamber. However, it would rather seem that these marble fragments had been used for securing the ashlars and the larger stone slabs.

The ashlar walls of the burial chamber were constructed and worked using the same materials and techniques as the Romanesque portions of the cathedral, whose details can still be observed in the main apse, the sanctuary steps, the gravestones and the 12th-13th-century carvings. An ashlar carved with an equal-armed cross in the crowning of the chamber's eastern wall has a good analogy on a 12th-13th-century broken gravestone from Eger, suggesting that the burial chamber had been constructed in the 12th century or the early 13th century as part of the Árpádian Age portion of the cathedral. The construction date of the burial chamber within this broad, roughly century-long period can be narrowed down on the testimony of the "marble plaques" found in the bedding perhaps the remnants of an ornate floor or the workshop debris of small architecture - to around 1200, when the cathedral's interior was embellished and enhanced with "marble architecture". The literary sources and historical record greatly restrict the circle of potential candidates who had perhaps been buried in the chamber at the turn of the 12th and 13th centuries. 